\title{
From the editor of the issue
}

Kate Dreyfus on a Jewish German jazz band exiled down under in 1939, portrayed in a documentary with some questionable features. Susanne Braun-Bau on the differences and commonalities of vocational training in Australia and Germany, with surprisingly good features identified in the former. Mandy Kretzschmar on how Australians changed their perceptions of Europeans after the 'Great War', with intriguing images culled from Australian journals such as The Bulletin. The racism and national prejudices which underpinned Australian political cartooning then is hard to believe. Post-structural Oliver Haag debating the truth/fiction binary in Aboriginal life writing and exposing astonishingly different perceptions between the writers and the critics of the genre. And finally Martin Grosch addressing a truly 'burning' issue for our times: how Sydney's urban sprawl is the main factor behind to the seemingly unstoppable rise in greenhouse gas emissions in Australia's five metropolitan cities (or "teeming sores" according to A.D. Hope.) But he also reports on some promising trends to revert the process. These are the five major essays in this new volume, but some of the reviews are hardly less than that. Consider Horst Prießnitz reviewing the New Cambridge History of Australian literature - he digs much deeper than your standard review would do and investigates the traditions of National literary histories as well as national Anthologies. "Never before" he boldly claims, "has a literary history been more willing to acknowledge Australia's embeddedness in overseas literary currents and socio-cultural developments." You will also enjoy Corinna Erckenbrechts review of an Outback thriller, one (the review not the thriller) that bubbles with topical issues and presents a wild menagerie of stock 'Aussie' characters:

cattle barons, magicians, prospectors, engineers, politicos, lawyers, game keepers, anthropologists, trackers, minors, mechanics, butchers, water-deviners, cops, water managers ...

and many more, more than can be mentioned here. Her enthusiasm with this tale is infectious. Or if you are more the academic type, then you will be delighted with Anja Schwarz's double review of Kate 
Grenville's two latest novels - and impressed with her critical acumen. Last but definitely not least I want to mention our multitalented transatlantic friend Mr Birns, who is giving us a bravura analysis of David Malouf's complex narrative art, exemplified by his approach to the Iliad, in Malouf's latest novel Ransom. As well, there is new poetry by Robyn Rowland, Diane Fahey, Beate Josephi and George Nicholson. In short, the contributors and I have endeavoured to put together another fat volume of learned, entertaining, sometimes provoking and polemical essays. Enjoy!

Klagenfurt, June 2010, Adi Wimmer

\section{Vorwort des Herausgebers dieser Nummer}

Kate Dreyfus schreibt über die "Syncopators", eine deutsch-jüdische Combo im australischen Kriegsexil. Susanne Braun-Bau erhellt Unterschiede im deutschen und australischen Berufsschulensystem und stellt überraschende Stärken des letzteren fest. Mandy Kretzschmar analysiert kollektive australische Sichtweisen auf Europa in der Zwischenkriegszeit und bezieht sich dabei auf interessantes Cartoon-Material. Oliver Haag brilliert mit einer poststrukturalistischen Analyse über den Wahrheitsgehalt von indigenen Autobiografien und konstatiert, dass die Autor/inn/en diesbezüglich ganz anders über ihre Texte denken als die Kritiker. Und schließlich legt Martin Grosch eine profunde, mit Tabellen und Karten untermauerte Studie über verkehrsgeografische Aspekte des Großraums Sydney vor. Die Fehler der Vergangenheit (Stichwort "urban sprawl"; A.D. Hope bezeichnete die fünf großen Metropolen Australiens als "teeming sores") rächen sich jetzt trotz allem Gegensteuern mit ständig ansteigendem $\mathrm{CO} 2$ Ausstoß in einem urbanen Großraum.

Das sind die fünf großen Beiträge dieses Bandes. Nicht weniger interessant sind eine Vielzahl von Rezensionen. Beachten Sie diesmal besonders den Review Essay von Horst Prießnitz über die 
New Cambridge History of Australian literature, in welcher nach Prießnitz im Vergleich früheren, mehr oder weniger nationalistisch eingefärbten Ansätzen eine Hinwendung zu internationalen Wurzeln und Einflüssen Platz greift. "Never before", so lautet sein Resumé, "has a literary history been more willing to acknowledge Australia's embeddedness in overseas literary currents and socio-cultural developments." Begeistert hat mich auch Corinna Erckenbrechts Besprechung eines "Outback Thriller", in dem eine pralle Handlung den Leser kaum zum Verschnaufen kommen lässt. Wer in Rezensionen den akademischen Duktus präferiert, wird bei Anja Schwarz und ihrer Doppelrezension zweier Romane von Kate Grenville gut aufgehoben sein. Eine beachtliche wissenschaftliche Leistung. Nicht zu vergessen auf unseren 'amerikanischen Freund' Nic Birns, der den neuesten Roman David Maloufs Ransom wortgewandt und kenntnisreich analysiert.

Daneben gibt es wiederum neue Lyrik von Robyn Rowland, Diane Fahey, Beate Josephi und George Nicholson. Kurz gesagt, die 26 Beiträger/inn/en und ich haben eine weiterer, substantielle Ausgabe der ZfA auf die Beine gestellt. Ich wünsche viel Lesegenuss!

Klagenfurt, Juni 2010, Adi Wimmer 


\section{Kay Dreyfus}

\section{,Truth' and the telling of the past in the bio-documentary film Weintraubs Syncopators: Bis ans andere Ende der Welt}

This article is a critical examination of the telling of the past in the
German bio-historical documentary film Weintraubs Syncopators; bis ans andere Ende der Welt (Sander and Süssenbach, 2000). ${ }^{1}$ Analysis starts from, but also interrogates, the assumption that a documentary film shares a commitment to truthtelling with other forms of historical discourse. The discussion acknowledges the received notion that there is a fictive element involved in any structured retelling of the past (Rosenstone, 2006:91; Nicholls, 1991:107; Heilbrun, 1993:295-304), and recognises the complex layers of signification and interaction that can exist, in a film, between spoken text, images and music, the purposive ordering of which constitutes what Plantinga (1997:169) calls the film's "rhetorical project". The article focuses particularly on the film makers' handling of witness testimony, an element that may be seen to enhance the film's claim to represent actuality. It asks what the film's purpose is and how important absolute historical accuracy is to that purpose, as well as what kind of "truth" the viewer is invited to take away. The story demands that the film's German writers and production team nuance and explain not only a complex period in German history, but a difficult period in Australian

\footnotetext{
${ }^{1}$ Production details are as follows: Idee und Buch: Joerg Suessenbach;

Regie/Realisation: Klaus Sander, Joerg Suessenbach; Mitarbeit: Axel Fischer; Kamera:

Axel Fischer (BVK); Ton: Jan Bendel, Steve Foy; Schnitt: Uli Peschke; Tonmischung:

Clemens Grulich; Sprecher: Leon Boden, Jenny Groellmann, Uwe Mueller;

Projektentwicklung: Walter Brun, Henrike Maass, Corinna Volkmann; Produktion

Australien: Anette Heidenreich, Wendy Oaks, Nimrod Sztern-Adidle; Produktionsleitung:

Karl-Bernhard Koepsell, Karl Laabs; Redaktion: Heike Wilke (WDR), Olaf Rosenberg

(Arte); Eine Produktion der Cine Impuls KG fuer den WDR in Zusammenarbeit mit Arte; Media (Der Vetrieb wird gefördert mit Mitteln der EU), 2000; duration 65 minutes.

Credits and acknowledgements (including Australian crew and sources) may be found in the Newsletter No 8 of the Film Museum Berlin, May 2000, at

http://www.marlenedietrich.org/pdf/News08.pdf accessed June 2009.
} 
history as well. My critique asserts that, in realising a narrative requirement for a certain kind of opening and closing proposition, the film sets up a synchronicity that is more ideological than historically valid.

The topic is timely since, in late 2007, the Weintraub Syncopators came briefly before the notice of the Berlin public once again when the Neuköllner Oper produced Hans-Peter Kirchberg and Ulrike Gärtner's nostalgic (and necessarily ephemeral) music-theatre piece Jazz Odyssee-Die Legende einer Showband (Müller 2007), stimulating a degree of interest in the German media. I would assert, however, that this theatre piece could have neither the reach nor the potential influence of the film; to my knowledge the latter has screened in venues as disparate as the Jewish film festivals in Berlin, Sydney and Melbourne and at a jazz festival in the USA. ${ }^{2}$ Though the film is highly conventional in its narrative structure and approach, it warrants critical attention as, at the time of its production and still, the only publicly available extensive account of the story of the Berlin cabaret/jazz band known as the Weintraub Syncopators, from its beginning in 1920s Berlin to its point of dissolution in Sydney, Australia, in mid-1940. Moreover, as Dan Sipe (1998:379) asserts, the medium of the documentary film is arguably a "major influence on the public's historical consciousness".

The Weintraubs (as they became known in Australia) started life as the Tanzkapelle Stefan Weintraub in Berlin in 1924, a strictly amateur outfit made up of students trying to make some money on the side. There were several changes of personnel in the early years but by 1933, the band comprised the seven musicians who would come to Australia, six of whom were Jewish: Stefan Weintraub, Horst Graff, Emanuel Frischer (aka Manny Fisher), Cyril Schulvater, John Kurt Kaiser (aka Sydney John Kay) and Leo Weiss. ${ }^{3}$ The seventh, Freddie Gordon Wise, was an American citizen and not

\footnotetext{
${ }^{2}$ The film is listed at http://www.jewishfilm.com/jz32.html\# eintraubssyncopators, accessed January 2008, a site whose purpose is to highlight notable films and videos of Jewish interest to aid in Jewish film festival programming. In 2008, it was also screened at the Lionel Hampton International Jazz Festival, University of Idaho.

${ }^{3}$ The name changes of some band members, before and after arriving in Australia, can and did generate some confusion. They were certainly a cause of grief to the Australian authorities; changing one's name unofficially during wartime was a breach of regulations.
} 
Jewish. Each musician was extremely gifted, a multi-soloist who could play at least half a dozen instruments.

Despite their international celebrity, the musicians found themselves debarred from continuing employment in Germany by the antiJewish, anti-foreign racial and cultural policies of the incoming Nazi regime, so embarked on an epic 4-year touring odyssey that took them, between March 1933 and July 1937, around Europe, across Russia to Japan and then through the Far East to Sydney. In an interview with Tempo, a monthly music trade magazine, in December 1938-January 1939, the band claimed to have "played in 459 venues, in 230 cities, in 21 countries" and to have "traveled 105,000 miles". The band did not become a touring group as a consequence of the Nazi embargos against foreigners, Jews and "negro jazz"; touring was an important part of the band's activities from as early as 1928 . Perhaps for this reason, the decision to leave Germany was easier than it was for other groups and artists. In the film, recurrent images of rolling train stock encode the journey metaphor and smooth chronological transitions.

The Weintraubs arrived in Australia in July 1937; by December 1938, they had secured a residency at an exclusive Sydney cabaret. But a series of events, some relating to general social anxieties directed towards nationals of enemy countries and some relating specifically to the musicians, brought them under official suspicion once war was declared. Most damagingly, the unsubstantiated civilian accusation that they had been German spies during their time in Russia resulted ultimately in the internment of three individuals in 1940 and the group's consequent disintegration, professionally and personally.

Graff, Weintraub and Kay were taken from their homes in the early hours of the morning of 6 June 1940 as part of a mass round-up of predominantly German nationals of military age who were living in Sydney's eastern suburbs, either close to or overlooking the entrance to Sydney Harbour, considered a highly sensitive military target. Though all three were subsequently released, the band never worked together again and Graff and Weintraub were, within a very short time, forced to find employment outside the music profession. The other musicians-the Polish brothers Manny and Ady Fisher 
(Adolph Frischer, aka Ady Fisher, replaced Freddy Wise after the band's New Zealand tour), and Leo Weiss, a German national who was, however, not interned-continued to play at Prince's until the Fishers were drafted in August 1943.

The film positions itself in relation to two generic paradigms, in accordance with its targeted constituencies: primarily audiences at Jewish or music/jazz film festivals. On the one hand, the film is a musical "tribute", the function of which is to celebrate, record, recover and restore, and the dominant mode of which is nostalgia. On the other hand, it seeks to recount the historical story of the Weintraubs, a story which also evokes a paradigm instantly recognisable to a Jewish audience: the axis of exile, the journey towards survival, loss and dislocation. The film succeeds as a tribute film because the musicians it celebrates were first class entertainers and because the European context in which the band flourished is lovingly recreated through contemporaneous images and footage, supported by original recordings and performance clips. The account of the band's story, however, and in particular its Australian wartime experience, is less convincingly handled. There is no historical Australian footage; no attempt is made to contextualise Australia's internment policy. Instead, the film makers rely on second-hand testimony for explanation, and do not redress any of the misconceptions or reductions which arise from serious (but almost certainly unwitting) flaws in these accounts.

The allocations of time in this 65-minute film are worth noting. The account of the first decade, from 1924-33, takes up thirty minutes, the four-year journey from Berlin to Sydney is covered in seventeen minutes, and the Australian chapter of their story occupies eleven minutes, of which three are taken up with a nostalgic recollection of Weintraubs' participation in the 1930 classic Josef von Sternberg film The Blue Angel. Insofar as the film indexes itself as a music tribute film, this is reasonable enough; Berlin in the 1920 s and early 1930s was a fascinating city, culturally and musically, and the band's early film clips and recordings produce absorbing visuals and an attractive soundtrack. The journey through Russia and Japan is enlivened by humourous anecdotes of the musicians' on- and offstage shenanigans from Ray Goldner, who was there, while recordings made with Russian and Japanese singers add an exotic 
touch of local musical colour. This was no harassed flight of traumatized refugees. These boys were stars; earning fabulous money, attracting glamorous women, they clowned and partied their way across the world. Australia is probably the least interesting part of the story musically since there are no Australian recordings, though there is some live performance footage from a Cinesound newsreel from 1937. And yet, events that occurred in Australia are imbued with enormous significance.

Exile (1933) and internment (1940) frame the narrative-the band's early career is recounted through an extended flashback-and substantial rhetorical and dramatic weight attaches to the underdeveloped account of internment as the cause of the group's dissolution. Additionally, by virtue of the fact that the story begins with exile and ends with internment, a structural link is established between these two injustices, indirectly but noticeably establishing a comparison between two regimes seen as hostile to an element within their populations ("Jews" in Germany, "enemy aliens" in Australia). When I first saw this documentary, I was captivated by the music and intrigued by the story, but under-informed. Watching the film now, having spent some years on a close analysis of Australian material relating to the Weintraubs' wartime experience (and particularly of files preserved in the National Archives of Australia), I observe the ways in which film artifice blurs the distinction between what is historically authentic and what is reductive, and the ways in which it "create[s] a fiction in the name $f$ truth" (Rosenstone:71).

\section{The layered narrative: chronicle, story and the film's "rhetorical project"}

The opening sequence of the film quickly and clearly establishes its parameters and its mode. To an accompaniment of one of the band's many recordings and a succession of still photographs of the musicians and iconic images of cities (some including the musicians, others not), a narrative is set in place that establishes the film's thematic content with five key statements, edited out of what were clearly longer interviews with protagonists in and witnesses to the story. Two concern the journey and three relate to the music, establishing the musicians' versatility, uniqueness and celebrity. The 
sequence introduces the two survivor protagonists (Ray [Fritz] Goldner and Ady Fisher) and two "experts" (a German jazz historian and a Japanese record collector). Goldner, the youngest of the troupe (he was born in 1915), joined the band as a stage assistant in Vienna in February 1935; Fisher came to Australia from Beirut in May 1938.

The structure of the film is orthodox: two decades in the life of the band are organised into a unitary, chronological story line, in which larger historical events are represented through their impact on this small group of individuals. Though particular musicians are highlighted in brief vignettes, the biographical subject is the band as a group, not its constituent members. In both chronology and the way it is put together, the film's narrative reproduces, almost exactly, that of the 1982 booklet by Horst J.P. Bergmeier, who is named in the credits of the film. Bergmeier's chronicle starts from discography and known performance venues, reconstructing chronology and changes in the band's personnel from evidence provided by recordings, programs and tour lists. Snippets of biography are interpolated, but the main purpose is to document and celebrate the recorded heritage. In the case of the film, this emphasis produces one consistently authentic element, the musical soundtrack, which is assembled from the band's recordings (including some made in Russia and Japan) and includes extracts from sound and promotional films in which it featured.

In imposing a narrative structure on the bare bones of Bergmeier's chronology, the film gives purposive shape to its arrangement of sounds and images, the means by which it projects its interpretation of the story. Particularly formulaic are the strategies-motifs that effect the transformation of chronicle into story-used to establish and conclude the narrative. The voice-over narrative begins with a "motif of inauguration" (White, 1973:5), positing "an initial 'steady' state that is violated and must be set right", or explained (Plantinga :126): "Berlin 1933.... the Weintraub Syncopators are one of the city's most popular jazz and show bands. But the young musicians cannot suspect that their lives are about to change dramatically". The film ends with what Plantinga (1997: 93) identifies as a common "terminating motif", a (ritual) celebration-in this case, a reunion, organised by Manny Fisher's wife Edzia in 1975. A group 
photograph of the now elderly musicians appears briefly on the screen.

An element of ambiguity attaches to the account of this latter event and the preceding narrative, but it is an ambiguity that results from what is left out, not from what is said. No hint is given that not all the members of the band were present at the reunion and no reference is made to the two musicians who did not attend: Leo Weiss and John Kay. Perhaps coincidentally, these are two who were able to continue successfully in musical careers-a fact that is also missing from the film's end narration, which describes how, after the war, "most of the musicians" went on to do other things. In fact, Weiss continued, without interruption until 1952, to direct an orchestra at Prince's, the Sydney cabaret at which all the Weintraubs were performing between December 1938 and June 1940, when three of the musicians were interned. On his release from internment, John Kay took up a lucrative position as musical director for the Colgate Palmolive radio show; he later established and managed the Mercury Theatre (with Peter Finch in the early 1950s) and wrote a number of scores for Australian feature and documentary films before relocating to London in 1955 . The effect of this omission is two-fold. First, it allows nostalgia to be the dominant affect at the end of the film, in lieu of the complexities that might arise from the inclusion of contradictory elements. Secondly, it preserves the hegemonic integrity of the text as a victim paradigm, reinforcing a thematic motif introduced at the start of the film.

The viewer can only speculate on the possible reason why all mention of these two individuals is avoided, but the omission could be read as reflecting one of the ideological conventions embedded in what film theorists call the "classic text", namely, to present a "welldefined chain of cause-and-effect which ends in satisfying closure" (Klinger 1984:37). According to such a view, "closure usually signals the ultimate containment of matters brought out in the narrativethe network of cause-and-effect is resolved, and the narrative returned to a final state of equilibrium" (Klinger:38). To admit exceptions to this formula is to disrupt closure and cloud the transparency of the explanation of the band's break up that constitutes the film's epistemological ending. Klinger (1984:37) notes "the expulsion of any feature which would distract from the 
hegemony of the narrative line". Perhaps also for this reason Goldner's departure for Brisbane is situated chronologically in the post-war commentary, implying that his departure was somehow a consequence of the war, though in fact he went to Brisbane before the band's New Zealand tour early in 1938.

Nostalgia is specifically evoked by the introduction and framing of The Blue Angel segment, out of chronological sequence, five minutes before the end of the film. (Situated chronologically, this segment would have occurred earlier in the film, during the flashback to the band's career in Berlin cabaret before the advent of the Nazi regime, and particularly in the extended discussion of its defining relationship with Friedrich Hollaender, the film's musical director and composer.) "The exciting times have all become memories now", we have just been told, as a Sydney record collector describes how tefan Weintraub, as an older man, would come to the collector's house to listen to the old tunes and reminisce.

The personal nostalgia associated with Stefan Weintraub's memories becomes generalised through the use of the refrain of the popular song My Melancholy Baby (words and music by George A. Norton and Ernie Burnett, 1912) as the underpinning of the final ten minutes of the film, preceding and following The Blue Angel segment and continuing under the closing credits. Sung in English, the refrain is the final textual element of the film. The sentimental longing expressed in the lyrics and the upbeat musical arrangement work to neutralize grief, overlaying the impact of the darker realities of 1930s Germany, the heart-breaking revelations of the post-war era for many German Jewish refugees, or even the more profound layers of loss that are intimated within the film.

\section{Witness testimony and the thinning of evidence.}

In a compilation documentary such as this, spoken word combines with images and music not just to evoke the past (though the film does this quite powerfully), but to make us feel something about the story being told: "[Film] does not simply provide an image of the past, it wants you to feel strongly about that image...Film does more than want to teach the lesson that history hurts; it wants you, the viewer, to experience the hurt (and pleasures) of the past" 
(Rosenstone:16). The witness-centred "voice of testimony" is used to substantiate or provide evidence for the film makers' or text's argument and to elicit feelings from the viewer. Onscreen witnesses testify to or describe the events depicted, enriching the expressive texture of the narration with their empathetic appeal while the onscreen close-up of the expressive human face allows us to register the power of past events by observing their impact in the present (Nicholls, 2001:42.). The use of real people, so-called "social actors" (as distinct from theatrical performers, Nicholls, 2001:5), reinforces the film's "claim to be an authentic recreation of the world as it was for these people", even though we no longer witness them "engaged in historical situations and events but in reflection and recall of such events" (Nicholls, 1991:252).

The visual element is critical: "We not only benefit from what is said, but from the visual and aural information available in how it is said from facial expression to gestures to inflections of the voice" (Plantinga:162.) So, for example, at the start of the film's main narrative, Ady Fisher, one of the two surviving musicians interviewed live, describes how, shortly after the Nazis took control of government, a young girl spat at him in a tram and called him "Jude" ["Jew"]. "We loved what we did", he says, "but they just didn't want us any more". This simple sentence, spoken by an old man with tears in his eyes, resonates with everything we know about the subsequent fate of Germany's Jews during the 1930s and 1940s. Given the power of the affect, it may seem that the person on screen speaks directly to the viewer but in fact his/her contribution is significantly mediated by what Plantinga (1997:151, citing Paul Messaris) calls "propositional editing". Only fragments of interviews are included, the questions are not heard and the questioner is not present, so the viewer has no knowledge of the larger content of the interview, either in terms of the give and take of dialogue or of the structuring role of the interviewer.

Though editing operates to "maintain logical continuity between individual viewpoints" (Nicholls, 1991:45.) and create a uniform perspective, there is, in fact, a complex of subjectivities among the witnesses in this film. Only two "subject-protagonists" appear in the film: Ray [Fritz] Goldner (the only witness to have been with the band in Russia) and Ady Fisher (who only played with the band from 
May 1938). Other witnesses include bystanders (people who knew the musicians personally or heard them play) and experts (principally jazz historians who can "place" the music and musicians in a wider musical and cultural context or substantiate claims about the quality of the musicianship). Archival interviews recorded in the past with now-deceased protagonists are absorbed into the voiceover narration.

Not all individuals speak of events of which they have direct knowledge, so that hearsay replaces testimony, at times at key points of the narrative. The explanation of why the Weintraubs broke up, for example, is divided between Stefan Weintraub's widow Bonnie, and Manny Fisher's wife Edzia, neither of whom was married to her musician husband at the time of the events of which she speaks:

(hesitantly) The Weintraubs broke up on account of the war...and ...um they were called in Australia displaced persons of course and....ah...life began to be a little more difficult for them here. (Bonnie Weintraub)

Around the middle of $1940 . . . S t e f a n$ Weintraub, Horst Graff and John Kaiser get turned in as Germans into the internment camp in Victoria. It's based on the belief that they are transmitting on Thursday nights through the radio some secret codes as spies to the Japanese. As hard as it is to believe, that's what the Australians are claiming and sending them off to an internment camp. (Edzia Fisher)

Bonnie's hesitations are intriguing, as is her evident discomfort in talking to the camera, a discomfort not evident in her earlier appearances. Her description of the musicians as "displaced persons" is inaccurate (though probably not deliberately intended to mislead), since "displaced persons" is the term used for post-war refugees. Its effect, though, is curious: "displaced persons" are clearly victims, of circumstance and the events of war; "enemy aliens", which is how Stefan Weintraub was classified, justly or unjustly, at the time of his internment, designates a group to which suspicion could hypothetically attach itself (and did). Her statement that the Weintraubs broke up on account of the war, while ultimately true, is so broad as to be largely uninformative, and also seems to contradict her earlier remark that Australia was a "safe country to be in.... far removed from Europe where trouble was and that's why 
they stayed". No further explanations are offered of what changed or what difficulties the musicians encountered.

The choice of Edzia Fisher to explain the circumstances surrounding the internment of three of the musicians in June 1940 is even more intriguing since, not only was she not married to Manny Fisher at the time, but he was not one of the three interned. Moreover, Stefan Weintraub is the implicit subject of the end of the film: his memories frame The Blue Angel flashback and his estrangement introduces the post-war reunion. So why does his widow not speak about Weintraub's internment?

There is indeed a link between an (unproven) allegation of espionage and the internment of the three musicians named by Mrs Fisher, but the charge involved the band's activities in Russia (see Dreyfus 2008) and is not mentioned in the film. Mrs Fisher's recollection is, I believe, based on another, later, incident that is recorded in the Fisher brothers' wartime security file in the National Archives of Australia. As is mentioned in the film, Ady and Manny Fisher, together with Leo Weiss (a German national who was not interned), continued in their employment as musicians for some time after the other members of the band had been interned. In March 1942, after Pearl Harbour, an internal military security memo, reporting a phone call from a local Passport Guard, noted that a group under the name of "Manny Fisher's Sextet" was broadcasting from radio $2 U W$ on Thursdays. The memo concludes, "as the majority of the band must be subject to suspicion, perhaps an inquiry might be made as to the facts and the material broadcast ascertained". ${ }^{4}$ Inquiries into the content of the broadcast were duly made and Manny was interviewed by Military Intelligence, ${ }^{5}$ but there is no record of any further action on this matter.

With its historical inaccuracies left unscrutinised, Mrs Fisher's anecdote serves only to trivialize the legitimate military and national security concerns that shaped Australia's internment policy in 1940, however prejudicially applied. The most cursory examination of a Sydney newspaper of 6 June 1940, the day on which the three musicians were arrested, would have alerted the film makers to the

\footnotetext{
${ }^{4}$ Initialed memo, 9? March 1942, File C123/1, Item 1211, 'E. \& M. Fisher,' NAA. ${ }^{5}$ Handwritten note, dated 20 March 1942, File C123/1, Item 1211, 'E. \& M. Fisher-1211,' NAA. A transcript of the broadcast, reports of the interview and detailed notes on the individual musicians are included in the file.
} 
reality of domestic concerns about the war, and of the internment operation that took place on that day. Page 1 of the Sydney Morning Herald, 6 June 1940, carried a report of heavy German bombing in central France. High levels of anxiety attached to the apparent ease of the German conquest of Europe and the pressure on British and Dominion forces (witness the evacuation from Dunkirk). In the same newspaper ( $p .9$ ) they would have noted how, after the fall of the Low Countries in May 1940, fears of fifth column activities among "phony" refugees, particularly those of German and Austrian nationality (so-called "enemy aliens"), had triggered vigourous local debate over whether or not all refugees should be interned for the public good. The problem is that internment was not universal. Inconsistencies and injustices often arose from its selectivity, particularly in the treatment of Jewish refugees, who were targeted and often interned, as indeed were Graff and Weintraub, along with Germans associated with or sympathetic to the Nazi Party. It could be argued that all three of the Weintraubs, as Jews, were interned unjustly, though an official case was assembled against each individual. But no distinction was made in the classification of Jews and non-Jews of German and Austrian nationality as "enemy aliens" until 1942, when a class of "refugee aliens" was created, or more comprehensively in 1944, when the definitions in the National Security (Aliens Service) Regulations were amended (Bartrop 1988:275, 278.).

Various issues cluster around the relationship of filmmaker and witness in a documentary film. First there is the historical status of the evidence itself. As in oral history, witnesses claim the authority (or surrogate authority, as in the case of the wives and widows) of a first hand knowledge of events that results from "having been there". For example, Edzia Fisher, as Edna Sztern, interviewed both Manny and Ady Fisher for the Shoah Foundation in July and August 1996. But does this formal connection enhance her reliability as keeper of her husband's memories? In film, because of the way they are subsumed into the narration, "oral histories tend to function... as pieces of argumentation rather than as primary source material still in need of conceptual organization" (Nicholls, 1991:252.) Ethical considerations attend the film-maker's relationship to witnesses as real people: how is the testimony of witnesses to be contested or 
qualified within a film "without running the risk of appearing to disbelieve, discredit or mock them?" (Nicholls, 1991:252). On the other hand, the absence of oppositional testimony or contesting voices, as here, may raise the question of whether the filmmaker has chosen to include only those anecdotes that smoothly advance or support the rhetorical argument of the film.

The brief, out of context witness statements included in this film are too mediated to support a discussion of the vexed relationship between memory, witness and testimony. At issue here is neither the reliability of the witnesses nor the value of their subjectivity. At issue is the effect of the statements as they are included and the film makers' failure, as in the examples (discussed above) that carry significant evidential weight, to navigate between memory as it survives within families and the detailed historical record as it survives in public archives.

\section{Conclusion: What does this documentary document?}

The documentary film, by taking what Plantinga (1997:18) calls an "assertive stance" in relation to actuality, makes a claim to represent the world (not "a" world) as it was (Nicholls, 1991: 109), and our complicit belief in or acceptance of this claim is essential to the communication of the film maker's view or argument (Plantinga $: 18,220)$.

If this film is to be taken seriously as a contribution to the public discourse on its topic, then truth has to matter. But while such an affirmation is easy to make, it is less easy to apply in all the situations generated within the complex medium of film. Rosenstone (2006:28), for example, problematises the proposition by asking what kind of truth it is that we should look for: factual, narrative, emotional, psychological or symbolic. Ady Fisher's statement "they just didn't want us any more", enhanced as it is by temporal placement at the start of the film, undoubtedly carries emotional "truth". Is it of consequence, then, that the "we" of whom he speaks cannot be the Weintraubs, despite the contextual implication that it is, since he did not join the band until May 1938 in Sydney, or that he did not leave Berlin until 1935, not in 1933 as the commentary implies? We respond because, irrespective of such details, his 
comment encapsulates all the gratuitous and arbitrary lawlessness and localised brutalities of the early months of the Third Reich. Similarly, the manifest discomfort and hesitancy of Bonnie Weintraub's attempt to explain why the Weintraubs broke up has an implicit emotional truth, aimed at protecting the memory of her husband. However, in its reliance on recollection (witness and testimony) to provide explanations of key historical incidents, the film appears to offer a somewhat uncritical endorsement of views that are, at times, partial or inaccurate.

There is one aspect of the Weintraubs' story that makes it rather different from many other exile stories, inasmuch as their career did not end when they left Berlin. Already established as a successful touring ensemble when the musicians took their decision not to return to Germany, they simply continued doing what they had always done, albeit with local variations that may be appreciated from recordings used in the film. In this they stand in contrast, for example, to the Comedian Harmonists, a contemporaneous vocal group, also from Berlin but not all Jewish, which broke up once the Jewish members left. In terms of the questions the film poses and then answers, it is internment, not exile, that marks the end of the group as an entity. It is Australia's treatment of the musicians, not Germany's, which emerges as responsible for the group's artistic destruction. Plantinga (1997:131) writes that "formal endings guide the backward-directed activity of the spectator in comprehending the film". It is a matter of importance, therefore, whether three sentences of flawed witness testimony are enough to do justice to the complexities of Australia's wartime internment policy.

For most theorists of film as history, the reductive pressures within the textual narrative, its "thinning of data" (White, 1998:1197, citing Rosenstone) are the single most problematic feature, especially when allied to a strong drive towards presenting "a unified representation of a subject, marked by a clear contextualization of knowledge within a relatively conventional structure" (Plantinga:115). For me, this film's usefulness as a historical document is undermined by the unevenness of its representation of two very different social, political and cultural environments 
(Germany and Australia) and by a simplistic appeal to the subjectivities of its target (Jewish or musical) audience. Most difficult, even if largely unnoticed, is the implied synchronicity between the film's opening-Nazi treatment of the Jews [expulsion, exile]-and its ending-Australian treatment of the same group of Jews [arbitrary internment, loss of profession]. Though Australia's World War II refugee policy has deplorable aspects (which are well documented in the scholarly literature), there are no parallels to be made between a totalitarian regime with murderous racial policies and even a temporarily de-liberalised wartime democracy.

\section{References}

Bartrop, Paul R. 1988. "Enemy Aliens or Stateless Persons? The Legal Status of Refugees from Germany in Wartime Australia". Journal of the Australian Jewish Historical Society X(4): 270-80.

Bergmeier, H.J.P. 1982. The Weintraub Story: Incorporated the Ady Rosner Story. Johannesburg: H.J.P. Bergmeier and der Jazzfreund, Menden.

Dreyfus, Kay. 2008. "Musicians in Trouble: The Sad Case of the Weintraub Syncopators", in Sheila Fitzpatrick and Carolyn Rasmussen eds., Political Tourists: Australian Visitors to the Soviet Union in the 1930s and 1940s. Melbourne: Melbourne University Press, 190-211.

Heilbrun, Carolyn G. 1993. "Is Biography Fiction?", Soundings 76(2-3) (Summer/Fall): 295-304.

Klinger, Barbara. 1984. ''Cinema/Ideology/Criticism' Revisited-The Progressive Text". Screen 25(1): 30-44.

Müller, Gerhard. "Weintraubs Jazz Odyssee". Programmheft Nr. 33, 11 December 2007. See http://www.berliner-philharmoniker.de/ konzerte/kalender/programmdetails/konzert/2994/termin/2007-12-1120-00/ (accessed February 2010).

Nicholls, Bill. 1991. Representing Reality: Issues and Concepts in Documentary. Bloomington: Indiana University Press.

Nicholls, Bill. 2001. Introduction to Documentary. Bloomington: Indiana University Press.

Plantinga, Carl R. 1997. Rhetoric and Representation in Nonfiction Film. Cambridge: The Press Syndicate of the University of Cambridge.

Rosenstone, Robert A. 2006. History on Film/Film on History. Harlow, UK: Pearson Education Limited.

Sipe, Dan. 1998. "The Future of Oral History and Moving Images", in Robert Perks and Alistair Thomson, eds. The Oral History Reader. London and New York: Routledge.

White, Hayden. 1973. Metahistory: The Historical Imagination in Nineteenth-century Europe. Baltimore \& London: The Johns Hopkins University Press.

White, Hayden. 1988. "Historiography and Historiophoty". The American Historical Review 93(5), 1193-99. 


\section{A N T I PODES}

\section{A North American Journal of Australian Literary Studies}

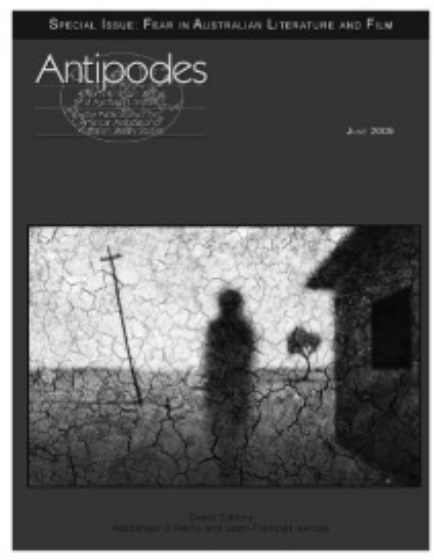

Since 1987, Antipodes has dedicated its pages to the practice and study of Australian literature and is now enjoyed by leading academics and enthusiasts around the world.

Our fully refereed scholarly essays cover a broad range of literary and cultural topics from a variety of critical perspectives. In-depth interviews offer intimate portraits of contemporary writers and artists.

In addition to new work by established authors, Antipodes introduces readers to the diverse voices emerging across mainland Australia, Tasmania, and New Zealand.

Recent issues have featured fiction from Michael Wilding and Ouyang Yu; creative non-fiction from Stephen Oliver and Elizabeth Bernays; poetry from Bronwyn Lea and Chris Wallace-Crabbe; and interviews with Tara June Winch and Hsu-Ming Teo.

Each issue of Antipodes also includes an extensive book review section, keeping readers up-to-date with the latest creative and scholarly work in the field of Australian literary studies.

Antipodes is published twice yearly, in June and December, by the American Association of Australian Literary Studies (AAALS). Association membership fees, which inlcude a subscription to the journal, are as follows:

$\$ 50$ Individuals \$60 Joint/Group/Institution \$30 Retired/Students

For more information, visit the AAALS website at www.australianliterature.org 


\section{Susanne Braun-Bau}

\section{Berufliche Bildung in Australien}

Мarum lohnt ein Blick auf das australische Berufsbildungssystem für europäische Bildungsreformer?

1. Die Einrichtungen für berufliche Bildung und Weiterbildung in Australien achten systematisch darauf, dass das Gelernte direkt am Arbeitsplatz umgesetzt werden kann.

2. Ein besonders breites Kursangebot steht zur Verfügung. Dabei werden berufsbildende Kurse an Instituten für Berufs- und Weiterbildung (Technical and Further Education, TAFE) oder an privaten Einrichtungen und an vielen Hochschulen angeboten.

3. Australien verfügt damit über ein - auch quantitativ - hoch entwickeltes berufliches sowie über ein ebenso breites hochschulisches Bildungssystem, die beide gleich etabliert sind.

Wie hat sich das Berufsbildungssystem in Australien (vocational education and training - VET) historisch entwickelt?

Das australische Bildungssystem wurde natürlich lange Zeit durch Großbritannien geprägt. Eine geregelte Berufsbildung führten die Engländer im 19. Jahrhundert ein. Nach der Gründung des Commonwealth 1901 verblieben Bildungsfragen und damit auch Ausbildungsangelegenheiten bei den einzelnen Bundesstaaten. Bereits im Jahr 1930 wurde der "Australian Education Council" gegründet. Die Bildungsminister der einzelnen Staaten und Territorien setzten sich hier für die Finanzierung der Berufsbildung ein. Damit war entschieden, dass neben einer praktischen Ausbildung im Unternehmen auch eine theoretische, aber praxisbezogene Schulausbildung absolviert werden soll.

In den letzten Jahren hat sich das australische Berufsbildungswesen grundlegend und recht eigenständig weiterentwickelt. "Mechanical Institutes", "Technical Colleges" und "Technical Secondary Schools" wurden nach und nach als Berufsbildungseinrichtungen etabliert. 
Wie in Deutschland kam es zu diesen Reformen, weil Regierung und Industrie einen Mangel an qualifizierten Fachkräften beklagten. Zugleich sind Regierung und Industrie bereit, mehr in Ausbildung zu investieren. Nach der Rezession zu Beginn der achtziger Jahre wurden neue Ausbildungsgänge und das nationale Berufsbildungssystem etabliert. Erstmals konnten Auszubildende nicht nur in einem Unternehmen, sondern in Unternehmensverbünden, sogenannten "Group Training Companies", die sich speziell zur Qualifizierung von Auszubildenden zusammenschlossen, Erfahrungen sammeln.

1994 erschien der Fitzgerald-Report, welcher die Grundlagen für das heutige berufliche Bildungssystem in Australien schaffte (vgl. www.dest.gov.au/sectors/training skills/policy issues reviews/key issues hts/vet/history.htm).

- Er umfasst flexible Ausbildungsgänge.

- Bundesstaaten und Territorien sollten für die Vergabe von Abschlüssen und die Akkreditierung von Ausbildungsinstitutionen verantwortlich zeichnen.

- Betont wird besonders die enge Verbindung zur Industrie.

- Schwerpunkt ist außerdem die Einführung eines "National Training Frameworks".

- Berufsbildung wird damit auch an der Highschool angeboten.

- Wie in Deutschland gibt es vollzeit- und teilzeitschulische Lehrgänge, die aber in Australien in der Regel auch selbst finanziert werden müssen.

Der letzte Punkt lässt aus deutscher Perspektive aufmerken: Statt Ausbildungsvergütung laut Berufsbildungsgesetz (BBiG) oder Unterstützung durch BAFÖG ist in Australien die finanzielle Eigenbeteiligung durchaus üblich.

Zur Verbesserung und Weiterentwicklung des Ausbildungssystems wurde parallel dazu bereits 1990 die "Australian National Training Authority" gegründet. Im letzten Jahr erst wurde diese durch einen unabhängigen "national regulator for the vocational education and training" ergänzt, der bei Registrierung der Institutionen und ihrer 
Kooperation oder Vernetzung unterstützen soll. (siehe: www.deewr.gov.au/Ministers/Gillard/Media/Releases/Pages/Article_0 91207_165252.aspx)

Neben dem Wunsch sich weiterzubilden oder sich beruflich zu verbessern, ist es aktuell auch wieder die Angst vor Arbeitslosigkeit, die viele Beschäftigte in weiterqualifizierende Maßnahmen treibt.

Jüngste Programme, wie etwa der Ausbau der "Trade Training Centres in Schools" sind relevante Teile der als "Bildungsrevolution" ausgerufenen aktuellen Neuerungen. 2,5 Milliarden Australische Dollar über zehn Jahre verteilt sollen es weiterführenden Schulen ermöglichen, Unterstützung zwischen AS $\$ 500,000$ and $\$ 1.5$ Million zu erhalten, um solche Zentren an der eigenen Schule zu etablieren.

\section{Wie funktioniert das australische Berufsbildungssystem heute?}

Die "Primary- und Junior Secondary School" umfasst zehn Schuljahre. Danach können Schülerinnen und Schüler eine Berufsausbildung an einer berufsbildenden staatlichen oder privaten Berufsakademie starten. Die meisten Schüler besuchen jedoch die 11. und 12. Klasse der "Senior Secondary School", um eine Berechtigung für ein Hochschulstudium zu erhalten. Einige Schulen bieten während dieser Zeit sogenannte "Mentorenprogramme" an, die Kontakte zwischen Schülern und Berufstätigen herstellen. Das folgende Schaubild zeigt die australischen Lernwege und Abschlüsse (Abbildung 1)

Abbildung 1

\begin{tabular}{|l|l|l|}
\hline School & $\begin{array}{l}\text { Vocational } \\
\text { Education }\end{array}$ & $\begin{array}{l}\text { University and Higher } \\
\text { Education }\end{array}$ \\
\hline $\begin{array}{l}\text { Senior Secondary School mit } \\
\text { Abschluss: Certificate of Education }\end{array}$ & & \\
\hline Certificates I - IV & \multicolumn{1}{|l|}{ Diploma and Advanced Diploma } \\
\hline
\end{tabular}




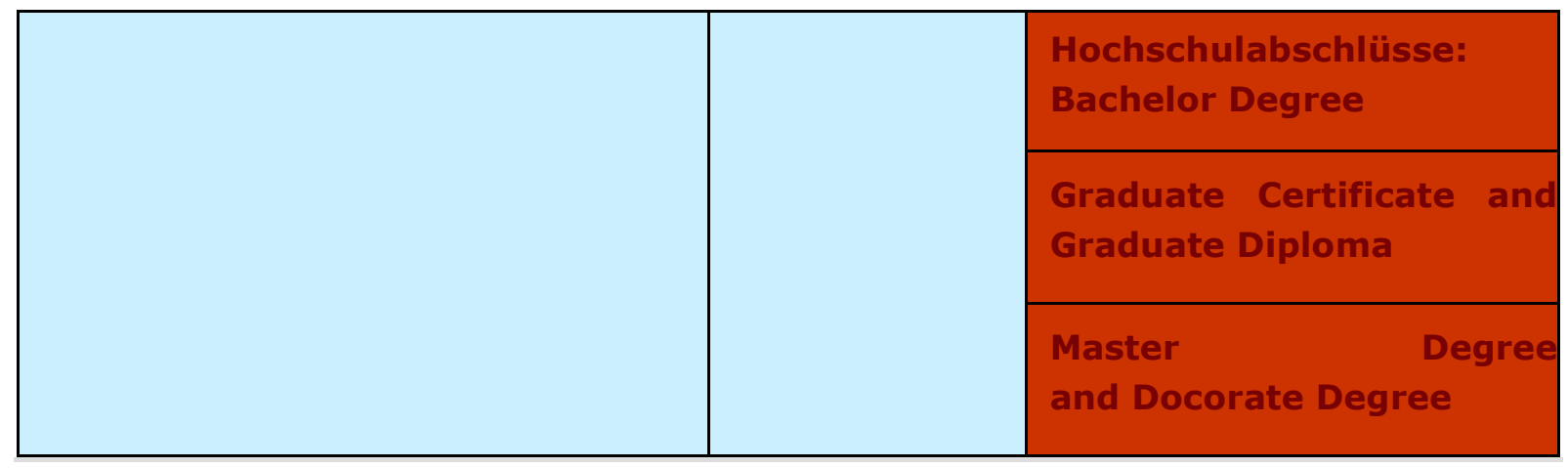

leicht überarbeitete Quelle: www.australien-studium.info/australischesbildungssystem/

Die Zahl der Examinierten, die in Australien eine Berufsausbildung nach einem Hochschulstudium beginnen, wächst - anders als in Deutschland - stetig. Grund für diesen - nach deutschem Verständnis - Übertritt in die "falsche Richtung" ist der hohe Anteil an Jugendlichen, die nach der schulischen Ausbildung ein Studium beginnen. Nach der letzten OECD-Studie von 2009 lag dieser bei 86 Prozent. In Deutschland begannen 2009 lediglich 34 Prozent ein Hochschulstudium.

Wie in Deutschland steht das System Schülerinnen und Schülern sowie Jugendlichen mit Schulabschluss zur Verfügung. Anders als in Deutschland nehmen dort jedoch breite Teile der Bevölkerung, nämlich Arbeitnehmerinnen und Arbeitnehmer praktisch jeden Alters, an einer Ausbildung teil. Die Ausbildungsvergütung richtet sich nach den persönlichen Voraussetzungen. Sie wird also stets neu verhandelt. Allerdings sind - anders als in Deutschland vollzeitschulische Einrichtungen häufig gebührenpflichtig. Dauer und Art der Ausbildung richtet sich ebenfalls nach den Vorqualifikationen. Landesweit gültige Qualifikationsschemata sorgen bereits heute dafür, dass Ausbildungswege durchschaubar und Übertritte, etwa in universitäre Studiengänge, flexibel bleiben.

Dies ist eine Entwicklung, die laut Beschluss der Kultusministerkonferenz, auch deutschlandweit umgesetzt werden soll. Verbessert werden muss demnach die Anrechnung beruflicher Qualifikationen auf Hochschulstudiengänge. Pauschalisierte Anrechnungen für homogene Bewerbergruppen sollen erleichtert werden. 


\section{Credit System}

Die Institutionen vergeben sogenannte "Credits" zur Anrechung auf einen weiteren Bildungsgang, etwa einen Hochschulstudiengang. Dies funktioniert durchaus in beide Richtungen. Folgende Abschlüsse sind im berufsbildenden Bereich landesweit die Regel:

\begin{tabular}{|l|l|}
\hline Qualifikationen des berufsbildenden Bereichs (VET) & Ungefähre Kursdauer \\
\hline Certificate I & 6 Monate \\
\hline Certificate II & 6 Monate \\
\hline Certificate III & 6 Monate \\
\hline Certificate IV & 12 Monate \\
\hline Diploma & 12 Monate \\
\hline Advanced diploma & 6 - 12 Monate \\
\hline Vocational graduate certificate & 6 Monate \\
\hline Vocational graduate diploma & 12 Monate \\
\hline
\end{tabular}

Quelle: www.uniaustralien.com

Ein Certificate IV erhält man demnach nach ungefähr 30 Monaten. Alle Teilqualifikationen bauen sinnvoll aufeinander auf.

\section{New Apprenticeships}

Neben der traditionellen Lehrlingsausbildung gibt es kürzere und zeitlich offener gestaltete Angebote, sogenannte "Traineeships". Zumeist dauern Vollzeit-Traineeships etwa ein Jahr. Zunächst waren diese für leistungsschwache Jugendliche vorgesehen oder für Schülerinnen und Schüler mit Problemen in der Schule als Ersatz für Klasse 11 und 12 gedacht. Dies hat sich verändert. Mittlerweile ist es ein Angebot für eine sehr breite Gruppe. Beide Ausbildungsformen - traditionelle Lehrlingsausbildung und traineeships - werden unter dem Begriff "New Apprenticeships" zusammengefasst:

A 'New Apprenticeship' is an apprenticeship or traineeship that offers new training flexibilities, new support service 
arrangements and new opportunities for structured training. They cover full or part-time paid work and training, and lead to a national qualification." (siehe: www.tourismtraining.com.au/ Apprent/apprent.html)

Mehr als 1,7 Millionen Australier nahmen 2009 an einem beruflichen Ausbildungsgang teil. Das sind etwa 13 Prozent der arbeitsfähigen Bevölkerung. Damit nimmt Australien eine Spitzenposition ein (siehe www.australianapprenticeships.gov.au). Auffällig ist die sehr flexible Gestaltung der Ausbildungsgänge: So können die Lehrlinge über die Verteilung von theoretischer und praktischer Ausbildung mit entscheiden. Sie wählen unter vielen verschiedenen Anbietern oder können auch Online-Kurse nutzen. Wie in Deutschland gibt es Vollzeit- oder Teilzeitangebote. Allerdings kann die Ausbildung mit bestimmten Modulen auch bereits an der Highschool beginnen.

Dieser Weg bedeutet - anders als bisher in Deutschland - die Aufgabe des Berufsprinzips zugunsten eines modularen Ausbildungssystems. Es kann ein richtiger, da ökonomischerer Weg sein. Nicht über die Aufgabe des Berufsprinzips, aber über eine verstärkte Modularisierung wird daher auch deutschlandweit diskutiert.

\section{Training Packages}

Um etwa Vorleistungen dokumentieren und berücksichtigen zu können, wurden sogenannte "Training Packages" entwickelt. Sie beschreiben außerdem berufliche Kompetenzen und Grundlagen, um die Ausbildungsqualität evaluieren zu können. Außerdem enthalten sie Informationen für alle an einem Ausbildungsgang Beteiligten (siehe: www.governmentskills.com.au/content/view/640/700/ und www.ntis.gov.au. Letztere Seite listet alle bisher entwickelten Pakete). Es gibt Kurse, die lediglich wenige Stunden dauern, andere haben einen Dauer von über 170 Ausbildungsstunden. Dies zeigt, dass diesen "Training Packages" - anders als den Ausbildungsgängen in Deutschland - kein standardisierter Lehrplan zugrunde liegt.

Damit auch "informell" erworbene Leistungen anerkannt werden können, wurde 1992 das Gremium der Ministers of Vocational Education, Employment and Training (MOVEET) gegründet, das 
danach vom Ministerial Council on Education, Employment, Training and Youth Affairs (MCEETYA) abgelöst wurde. Das MOVEET entwickelte damals eine sogenannte "Orientierungsrichtlinie" mit dem National Framework for Recognition of Training (NFROT). Da sich diese Richtlinie nicht bewährte, wurde sie vom Australian Recognition Framework (ARF) abgelöst. Dieser Rahmenplan wurde nun durch den Australian Quality Training Framework (AQTF) weiterentwickelt (seihe: www.ncver.edu.au/rexxources/glossary). Die Anerkennung der Vorleistungen kann durchaus aufwendig sein, bewirkt aber, dass ein Teil der Ausbildung nicht doppelt absolviert werden muss. Dieser Service ist zudem - anders als in Deutschland - überwiegend kostenfrei. Theoretisch könnten sogar verschiedenste Arten von Vorleistungen als komplette Ausbildung anerkannt werden. Dieses "Recognition of Prior Learning" dient durchaus auch dazu, um bei Neueinstellung in eine Firma auf eine höhere Lohnstufe hoffen zu dürfen.

\section{Industry Skill Councils}

Alle regionalen und lokalen "Training Authorities" sind dem Ministerium für berufliche Bildung in Australien (Department for Education, Employment and Workplace Relations, DEEWR) rechenschaftspflichtig. Registrierte Ausbildungseinrichtungen sind erst dann berechtigt, landesweit anerkannte Abschlüsse zu vergeben. Sogenannte "industry advisory bodies" mit Vertretern der Arbeitnehmer- und Arbeitgeberinstitutionen sorgten für einen angemessenen Austausch zwischen Industrie und Berufsbildungssystem. 2003 entschied die Australian National Training Authority (ANTA) mit elf neuen "Industry Skill Councils" diesen Austausch weiter zu verbessern (siehe: www.isc.org.au). Diese Gremien haben vor allem zwei Funktionen:

1. fundierte Kenntnisse über australische Unternehmen zu vermitteln, um den beruflichen Bildungssektor über gegenwärtige und zukünftige Ausbildungsnotwendigkeiten zu unterrichten;

2. Ausbildungsgänge und "Training Packages" kontinuierlich weiter zu entwickeln, zu verbessern oder bei der Neuimplementierung zu helfen. 
Der Bund-Länder-Koordinierungsausschuss und das Bundesinstitut für Berufsbildung haben im deutschen dualen System ähnliche Funktionen.

\section{Integrated Dual Sector Awards}

Zertifikate werden durchaus auch durch die Hochschulen einerseits und die beruflichen Schulen andererseits vergeben. Sogenannte "Integrated Dual Sector Awards" ermöglichen, dass etwa Einrichtungen der beruflichen Bildung und die Universitäten für einen Ausbildungsgang im Rahmen eines "dualen Studiums" zeitgleich besucht und mit Ihren Teilleistungen anerkannt werden können. (siehe: ANTA und Universities of Australia. "Draft Policy Guidelines on Cross-Sector Qualification Linkages": www.dest.gov.au/NR/rdonlyres/ A0812459-907E-484D-B1EC-822C3D02B7AA/10862/AQFDraftGuides8Nov2001. ttf)

Anders als in Deutschland sind Teilnehmende dieser Programme durchaus auch älter, da sich viele erst nach einem Universitätsstudium und mehreren beruflichen Praxisjahren für eine Berufsausbildung oder -weiterbildung entscheiden. Dies zeigt aber auch das aus deutscher Sicht ungewöhnliche Phänomen, dass viele Universitätsabsolventen sich anschließend noch beruflich neu orientieren oder im Anschluss eine berufliche Ausbildung als weitere Qualifizierung betrachten. Nur selten wird der Weg von der Berufsausbildung an die Universität genutzt. Gerade viele Frauen wählen nach der Hochschulprüfung eine Berufsausbildung in Teilzeit, um spezifische berufsrelevante Kenntnisse zu erwerben oder bestehende praktische Fähigkeiten aufzufrischen und sich für die am Arbeitsmarkt gefragten Berufe zu qualifizieren. Es scheint, dass Schwachstellen eines Hochschulsystems, das weitgehend vom Arbeitsmarkt abgekoppelt ist, durch das flexiblere berufliche Bildungssystem aufgefangen werden.

\section{The National Governance and Accountability Framework}

Die australische Regierung hat sich verpflichtet, für ein einheitliches und qualitativ hochwertiges Bildungssystem $\mathrm{zu}$ sorgen. Die Zuständigkeit und die Verantwortung einzelner Behörden unterscheidet sich jedoch - wie in Deutschland - zwischen den einzelnen Staaten und Territorien. 
Dem bereits erwähnten für Bildung und berufliche Bildung zuständigen Department of Education, Employment and Workplace Relations untersteht das Ministerial Council for Vocational and Technical Education. Dieser Institution obliegt die Verwaltung der Berufsbildung auf nationaler Ebene. Mitglieder sind die zuständigen Ressortminister der Bundesstaaten und Territorien sowie der australischen Regierung. Hier wird über strategische Planung und Finanzierung beraten. Das Gremium tritt einmal pro Jahr zusammen, um politische Ziele und neue Entwicklungsschwerpunkte zu beschließen. Auch Arbeitsmarktplanung und künftig benötigte Qualifikationen werden hier beraten.

In Deutschland sind ähnlich vergleichende "Bildungsgipfel" etabliert, auf denen Vertreterinnen und Vertreter der Kultusministerkonferenz sowie des Bildungsministeriums gemeinsam beraten.

Alle weiteren Gremien sind zusammen mit den Vertretungen in den Bundesstaaten und Territorien für die Ausgestaltung der Gesetze und deren Durchsetzung verantwortlich. Auch die Registrierung von Berufsbildungsanbietern und die Umsetzung des landesweit gültigen National Governance and Accontability Framework obliegt diesen Institutionen. Auf die Industry Skills Commitees wurde bereits eingegangen. Das National Senior Officials Committee sorgt für die Umsetzung der Entscheidungen und für die Verbindlichkeit bei der Umsetzung in den Staaten und Territorien. Das National Industry Skills Committee" erstellt in erster Linie Arbeitsmarkstudien, das Quality Council ist, wie bereits der Name verrät, für den Bereich der Qualitätssicherung zuständig (siehe Abbildung 2). 
Abbildung 2:

Ministerial Council for Vocational and Technical Education (MCVTE)

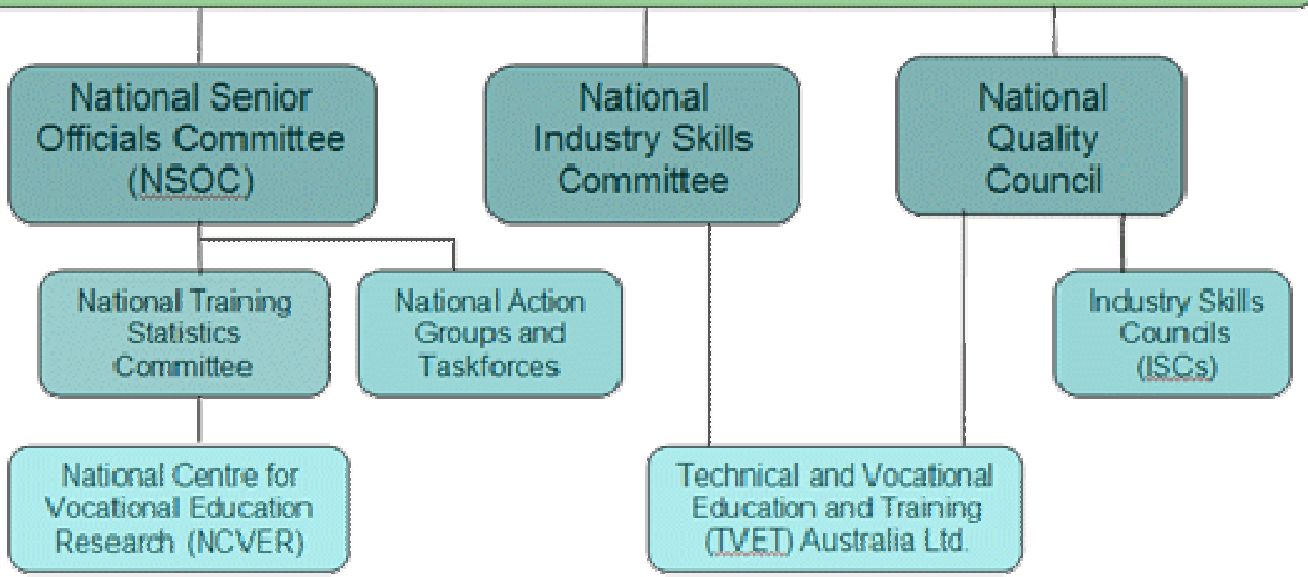

Quelle: Homepage des Department of Education, Employment and Workplace Relations (www.deewr.gov.au)

Abbildung 3 Anteil der TAFE-Absolventinnen und Absolventen, die Ende Mai ein Jahr nach ihrem Abschluss - einen Arbeitsplatz haben

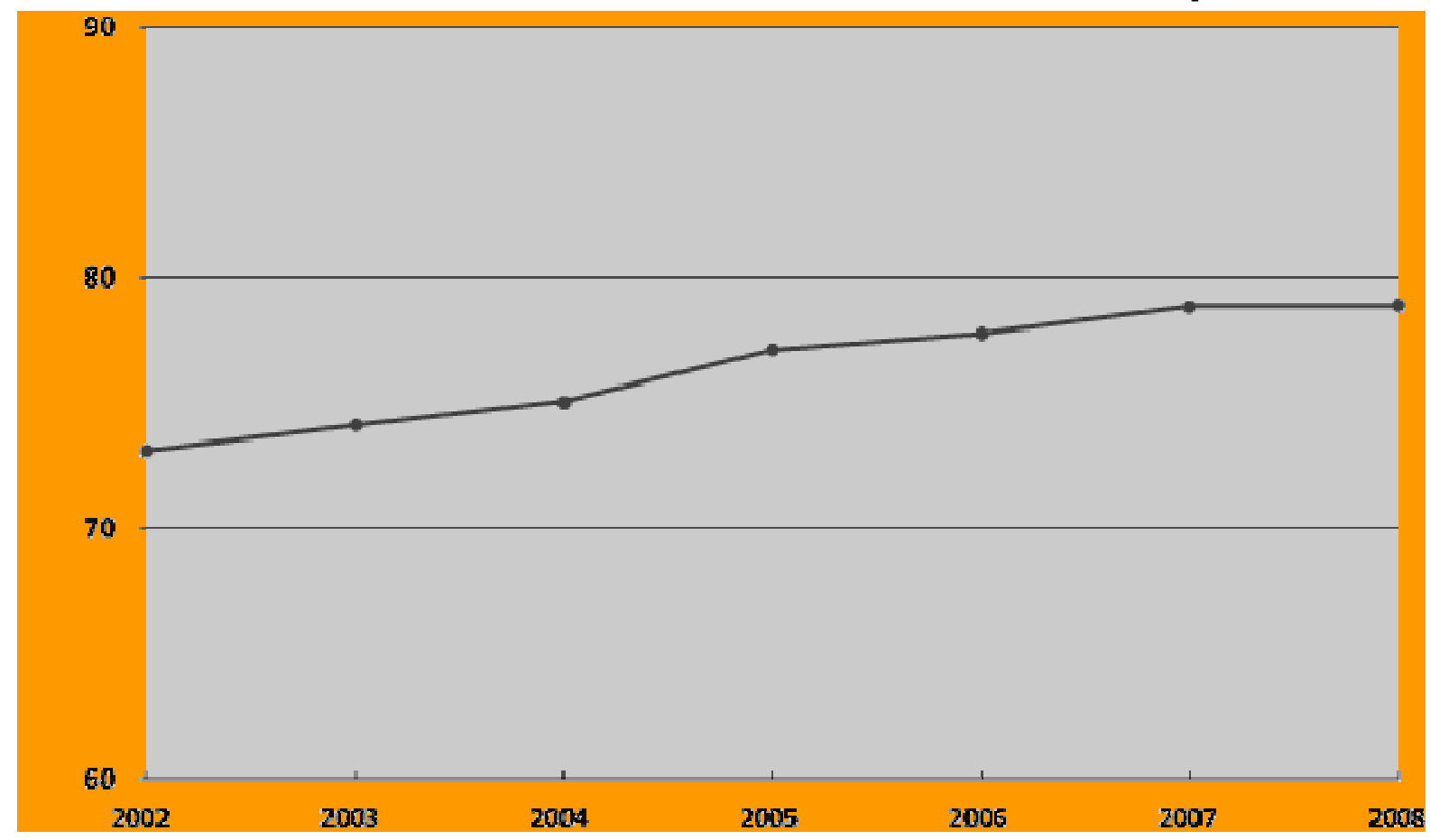

Quelle: National Centre for Vocational Education Research (NCVER) Student Outcomes Survey, 2002-08. 


\section{Was bringt die Zukunft?}

Anders als bei der etablierten Ausbildungsabgabe, die alle deutschen Unternehmen aufbringen müssen, zahlt die australische Regierung Subventionen oder Prämien an ausbildende Unternehmen, die zum Erhalt der Lehrlingsausbildung beitragen. Im Rahmen eines verbindlichen Vertrags mit den Jugendlichen (Job and Training Compact) sollen 90 Prozent aller Jugendlichen bis 2015 eine einjährige Ausbildung absolvieren. Auch die Zahl derer, die anschließend in feste Arbeitsverhältnisse wechseln, soll weiterhin stabil steigen (siehe Abbildung 3)

Das neue System "Job Services Australia", das im Juli 2009 begonnen hat, soll mit 2.100 Büros in ganz Australien dafür weitere Unterstützung leisten.

Dem dient auch der "Compact with Young Australians" von Dezember 2009:

\section{Learning or earning: New education and training requirements for 15 to 24 year olds}

All governments in Australia have agreed to a Compact with Young Australians, which comprises a National Youth Participation ('learn or earn') Requirement for under 17 year olds; an entitlement to education or training places for 15 to 24 year olds; and changes to Youth Allowance (Other) and Family Tax Benefit (Part A) for young people aged under 21 without Year 12 or an equivalent qualification, making education and training a precondition for income support.

"Awards for Excellence" werden jedes Jahr besonders erfolgreichen Absolventen der TAFE-Ausbildungen verliehen. Ein Instrument zur Qualitätssteigerung, das in diesem Bereich gut funktioniert. (siehe: www.annualreport.deewr.gov.au/2009/part 2/Outcome 4 01.)

Weitere wichtige Reformen der letzen Jahre umfassen: 
- die Einführung von Kompetenzmessungen und die Festlegung verbindlicher Ausbildungsgänge durch ein nationales Qualifikationsrahmenwerk,

- Wettbewerb zwischen den Ausbildungsorganisationen - gerade auch während der aktuell ausgerufenen Wirtschaftskrise als Konsequenz aus der globalen Rezession.

- outcome-orientierte Ausbildungsangebote

- eine Verzahnung zwischen Berufsschulen und berufsbildenden Einrichtungen sowie der Wirtschaft

- flexible Gestaltung verschiedener beruflicher Karrierewege (VollTeilzeit) sowie

- eine vermehrte Teilnahme von sozial benachteiligten Menschen an der beruflichen Bildung durch eine neue Institution, dem NEW National VET Equity Advisory Council.

Besonders die Einführung von Kompetenzmessungen und die Festlegung verbindlicher Ausbildungsgänge durch ein nationales Qualifikationsrahmenwerk sind aus deutscher Perspektive bemerkenswert. Bundesweit gibt es noch keine konsistenten Systeme, sondern lediglich die Rahmenvereinbarungen des dualen Systems.

Das Pendant zur Förderung von sozial benachteiligten Menschen ist in Nordrhein-Westfalen das Konzept zur Integration lernbehinderter Jugendlicher in Ausbildung und Arbeit (kurz ILJA). Dieses wurde von Vertreter des Arbeits- und des Schulministeriums, der Regionaldirektion der Bundesagentur für Arbeit, der kommunalen Spitzenverbände, der Optionskommunen und der Gesellschaft für innovative Beschäftigungsförderung erarbeitet.

Alle Einrichtungen müssen die Standards des "Australian Quality Training Framework" (AQTF von 2007) erfüllen. Diese legen genau fest, welche Kompetenzen am Ende eines Lehrgangs erreicht werden müssen. In Nordrhein-Westfalen sorgt hierfür der Landesausschuss für Berufsbildung. Ansätze gibt es auch bei der Bertelsmann-Stiftung mit dem Projekt "Übergänge mit System". Mit dieser Initiative sollen Übergangsmöglichkeiten für junge Menschen in Ausbildung verbessert werden. 
Die australische Lehrlingsausbildung ist führend in den englischsprachigen Ländern, denn sie qualifiziert in Schulen, Hochschulen oder durch Online-Angebote für mehr als 500 Berufe oder Tätigkeiten und kann am Ende der Schule aber auch zu einem flexibel späteren Zeitpunkt begonnen werden. Nicht umsonst unterhält auch das Bundesministerium für Bildung und Forschung seit einiger Zeit einen Informationsaustausch über Entwicklungen in der Berufsbildung in Australien und Deutschland. Bereits 1996 wurde hierzu ein Abkommen zur Zusammenarbeit in der beruflichen Bildung unterzeichnet. Deutsche Berufsbildungspolitiker, Wissenschaftler und Bildungsmanager besuchen Australien und umgekehrt. Es wurde erkannt, dass die neuen Ansätze zu mehr "Kundenorientierung" in den Bildungsangeboten sowie stärkerer Flexibilisierung führen und die "Training Packages" auch Anknüpfungspunkte für deutsche Modernisierungsbemühungen bieten.

Wenn im australischen System Auszubildende mehr und mehr als zahlende Kunden gesehen und Berufsschullehrkräfte als Servicedienstleister, Manager oder Berufberater verstanden werden, hat dies allerdings auch negative Konsequenzen. Diese Entwicklung hat in Australien dazu geführt, dass Konkurrenz und Wettbewerb der staatlichen und privaten Anbieter die Gehälter der Lehrenden negativ beeinflussen: Teilzeitverträge und flexible Einsatzbedingungen bewirken, dass viele Berufsschullehrkräfte nun an mehreren Schulen arbeiten müssen, um von ihrem Gehalt leben zu können.

Aktuelle Zahlen zeigen:

Im Dezember 2009 waren 424.000 Auszubildende in einer Lehrlingsausbildung. (Zum Vergleich: Allein in Nordrhein-Westfalen sind es zurzeit laut IT-NRW etwa 350.000 Auszubildende. Siehe: www.it.nrw.de) 156.900 Absolventen erreichten einen Abschluss. Das sind, laut Angaben des National Centre for Vocational Education Research (NCVER), 5,9 Prozent mehr als im Vorjahr. Allerdings ist auch die Zahl der Ausbildungsabbrecher mit 132.200 recht hoch.

Sehr gut sind die Einstiegschancen nach der Ausbildung. 93 Prozent der Auszubildenden sind kurze Zeit danach in fester Beschäftigung. Allerdings zeigt der Bericht auch, dass die Zahl der Teilnehmer ethnischer Minderheiten und hier insbesondere der indigenen 
Bevölkerung deutlich hinter den allgemeinen Teilnehmerzahlen zurückliegt.

\section{Fazit}

Ein Blick auf Australien ist aus deutscher Perspektive interessant. Es finden sich, wie dargelegt, interessante Unterschiede, aber auch Gemeinsamkeit bei den gemeinsamen Anstrengungen für eine positive wirtschaftliche Zukunft beider Länder sehr gut ausgebildete Fachkräfte zur Verfügung zu stellen, etwa das deutsche Konzept IIJA und australische Bemühungen zur Förderung benachteiligter Jugendlicher oder das Australian Quality Training Framework und das deutsche Projekt "Übergänge mit System. Einige besonders markante Unterschiede oder interessante Entwicklungen sollen abschließend kurz zusammengefasst werden.

1. Es fällt auf, dass es in Australien ebenfalls vollzeit- und teilzeitschulische Lehrgänge gibt. Statt Ausbildungsvergütung laut Berufsbildungsgesetz (BBiG) oder Unterstützung durch BAFÖG ist in Australien die finanzielle Eigenbeteiligung durchaus üblich.

2. Landesweit gültige Qualifikationsschemata sorgen dafür, dass der Übertritt, etwa in universitäre Studiengänge, flexibel bleibt. Dies ist eine Entwicklung, die laut Beschluss der Kultusministerkonferenz, auch in Deutschland umgesetzt werden soll. Verbessert und erleichter werden müssten demnach die Anrechnung beruflicher Qualifikationen auf Hochschulstudiengänge und etwa die pauschalisierte Anrechnung für homogene Bewerbergruppen.

3. Öffnet man die berufliche Ausbildung auch in Richtung der allgemeinbildenden Schule, so könnten - wie in Australien bestimmte Modulen auch bereits an der weiterführenden Schule absolviert werden. Dieser Weg bedeutet - anders als bisher in Deutschland - die Aufgabe des Berufsprinzips zugunsten eines modularen Ausbildungssystems. Es kann ein neuer und ökonomischerer Weg sein. Über eine verstärkte Modularisierung wird daher auch deutschlandweit diskutiert.

4. Vorbildlich scheint der australische Weg bei der Anerkennung von Vorleistungen, die verhindern dass Teile der Ausbildung doppelt 
absolviert werden und zudem - anders als in Deutschland überwiegend kostenfrei sind.

5. Besonders die Einführung von Kompetenzmessungen und die Festlegung verbindlicher Ausbildungsgänge durch ein nationales Qualifikationsrahmenwerk sind aus deutscher Perspektive bemerkenswert. Bundesweit gibt es noch keine konsistenten Systeme, sondern lediglich die Rahmenvereinbarungen des dualen Systems.

6. Besonders hinterfragt werden müsste m.E. folgender Aspekt: Es scheint, dass Schwachstellen eines Hochschulsystems, das weitgehend vom Arbeitsmarkt abgekoppelt ist, durch das flexiblere berufliche Bildungssystem aufgefangen werden.

Aus deutscher Perspektive stellen sich hier Zweifel und Fragen ein: Ist die hohe Akzeptanz beruflicher Bildung, die daraus spricht, dass sich auch Hochschulabsolventen für diese Richtung entscheiden wünschenswert? Oder zeigt sie vielmehr, dass australische Hochschulen nicht professionell genug arbeiten? Letztendlich scheint das deutsche System mit seinem zusätzlichen Angebot an Fachhochschulen hierauf nach wie vor eine besonders gute Antwort zu geben.

\section{Literatur:}

Curtin, Penelope, Loveder, Phil, eds., 2007. Informing policy and practice in Australia's vocational education and training sector. Reflections and futures. Proceedings of the 25th Anniversary Forum of the National Centre for Vocational Education Research. Adelaide: National Centre for Vocational Education Research.

Deissinger, Thomas, Smith, Erica, Pickersgill, Richard 2006. "Models of full-time and part-time vocational training for school-leavers: a comparison between Germany and Australia", International Journal of Training Research, Vol. 4 No.1, 30-50.

Department of Education, Employment and Workplace Relations. Annual Report 2008 und 2009. (Download unter: www.annualreport.deewr.gov.au)

Harris, Roger, Deissinger, Thomas, 2003. "Learning cultures for apprenticeships: a comparison of Germany and Australia". In Searle, J., Yashin-Shaw, I., Roebuck, D., eds. Enriching Learning Cultures: Proceedings of the 11th Annual International Conference on Post- 
compulsory Education and Training, Brisbane: Australian Academic Press. Vol. 2, 23-33.

Hellwig, Silke, 2006. "Kompetenzorientierung in der Berufsbildung: das australische Modell der Training Packages". In: Tarek Badawia et al. eds. Das Soziale gestalten. Wiesbaden: Verlag für Sozialwissenschaften, 77-88.

-- , 2006. "Competency-based training: different perceptions in Australia and Germany", Australian Journal of Adult Learning, Vol. 46 No.1, 51-73.

National Centre for Vocational Education Research, 2009. Apprentices \& Trainees. Australian vocational education \& training statistics. June Quarter 2009. Adelaide: NCVER. (Download unter: www.ncver.edu.au/statistic/publications/2213.html)

Organisation for Economic Cooperation and Development, 2009. Education at a Glance. Paris: OECD. 


\section{Mandy Kretzschmar}

\section{"Not good enough for Australian citizenship" - How Australians imagined Europeans in the 1920s}

The historical connections between Europe and Australia are profound. Europe has nurtured Western civilisation. Australia has inherited, embraced and adapted that great civilisational tradition. [...] The contribution of Europeans to Australia has been so strong that it almost seems redundant to mention it.

Kevin Rudd (2008)

There is a tendency within scholarship to narrate Australia's (recent) past as a one-directional flow of ideas, people and goods, a process in which Europe of course is the point of departure and Australia the target. Australian Prime Minister Kevin Rudd reflected on this process in his speech at the European Policy Centre in Brussels in April 2008. In this view, Australia was, and is still, a passive screen for European projections.

Recently, this Euro-centric approach has been subject to intense academic debate. The necessity of reconsidering and revising previous historical accounts of Australia's past - in particular the way in which European expansion and perspectives of the colonized are narrated - has gained momentum in debates such as the History Wars. The focus of academic attention has turned towards a history of interaction with the outside, in which each society influenced and significantly participated in forming the cultural identities of the other. This article considers these interactions, and posits that Australians have played an integral part in the processes of representing and defining what constitutes 'European' and have thus shaped European history in return.

Although there have been numerous studies in European identity, the construction of the 'European' - the 'imagined community' inhabiting Europe - has remained largely-unexamined. As notions of the European can be traced as far back as Antiquity, this is a 
surprising omission. Herodotus was among the first to describe Europeans in demarcation to Persians, drawing on cultural arguments (Schmale 2001:165). Beginning in the $19^{\text {th }}$ century, the image of the European has evolved as a significant category of demarcation and belonging, while today, it is implicitly used without scrutinising its implicit meanings (Bluche/ Patel/ Lipphardt 2009:11).

Despite the concept finding growing application, European historians have traditionally focused on writing a social history of ideas of Europe, in which the European person as the one inhabiting the geographical space has been reserved only a marginal role. With changes in political geography after 1989, after the collapse of 'real socialism' in Eastern Europe and the end of the Cold War, followed by an increased integration of the economies of the European Union, interest has shifted toward the issue of identities. In the social and political sciences, research focused on the complex interplay of selfimages and images of the Other in negotiating one's own understanding of the self. However, most of these studies have centred on questions of political identity with regard to the European Union and are limited to venues of construction within Europe. Historians such as Bo Strath, Michael Mann and Luisa Passerini however, have stressed that non-European societies have played an essential part in shaping self-images of Europe. In the past decade, a number of studies offering non-western perspectives - from China, Africa or the Asian Pacific region - on Europe were published. Within this context, Australia has gradually become recognized as an interesting case study.

It is enriching to study representations of the European from an Australian perspective. However, in regard to its international involvement, Australia's neglect in world historiography in general, and European history in particular, seems striking. Australia has always been an interesting case study: by virtue of her largely European cultural heritage since 'white' settlement, but with regard to her Indigenous peoples and geographical position, the question of Australia's belonging to either 'the West' or Asia is an exceptional one. It is assumed that this open status of belonging is reflected in 
multiple, diverging representations of the European, serving as one category of demarcation in defining one's own identity as Australian.

It is the aim of this article to identify dominant representations of the European in the Australian press and to stress their function in identity-building processes. Before turning to the empirical findings, I will provide an introductory overview on the study of representations as forms of organising knowledge. I will reflect on the substantial role of the press as a powerful source of these constructs. In the second part, the focus will be on the press debate about the 'white' settlement of the Australian Tropics in the 1920s to present many of the central issues in a concise form.

\section{Locating representations of a moving target}

Mental images serve as a structuring device for the organization of our daily lives. They reduce the complexities of the social and political data that we encounter in our social surrounding and shape our understanding of who we are and who the Others are and how we relate to one another. In short, they are a form of organised knowledge which is communicated in interaction. They are formed by individual and collective experiences and are mediated through traditions and culture as well as politics. As a result of their consolidation, such notions assume the status of social directives. Neither eternally fixed nor of lasting validity, representations are continuously subject to adaptation, change, re-invention, even replacement. The negotiation processes take place at a variety of societal levels the media, in science, politics and education.

Consider the following. In March 1920, the Australian weekly newspaper The Bulletin featured a reader's response by journalist Randolph Bedford. The heated argument between the anonymous authors 'Biologist' and 'Mere European' as well as Bedford about immigration restrictions and desired newcomers had evolved over several weeks. Once again, its author argued for a closer physical and mental examination of incoming foreigners: 
We are soon to close our doors against inferior goods, I hope, and to maintain our standard we must close our doors also against cheap humans, while combining the white races for the best they have. (...) 'There are hundreds of thousands of English and Europeans who are not good enough for Australian citizenship, and I asked for rigorous examination and discrimination of these.'

Disregarding Bedford's racial bias, this view illustrates the complex processes of negotiating one's own identity through contrastive representations of the Other. It provides a graphic example for Australia's discourse of belonging. Here, Australians as a social and political community share unifying qualities. They are characterised as hard-working, healthy and intelligent. In comparison to nonwhites ("cheap humans") and immigrants sharing the same racial background but opposed to Australian aspirations, Bedford argues that on the basis of their inherent characteristics Australians can be regarded as a superior race.

The article reflects Bedford's support for the White Australia Policy. The policy created a sense of unity against a racially defined external aggressor (Tavan 2005:14). In the above-mentioned example, Bedford differentiates between English and Europeans, indicating multi-layered and ambiguous relations toward a variety of Others. Indeed, this distinction implies a hierarchical social order privileging whiteness as a collectively shared concept that distinguishes Australians, Europeans and English from 'them'. Thereafter, it can be argued that 'European' is not predominantly used as a category to define geographical affiliation, but as a term for cultural identification. It serves as a notion of social belonging and a means of grouping. Lastly Bedford even performs an act of creativity for the purpose of demarcation. Considering that Australian citizenship was only created by the 1948 Australian Citizenship Act, the notion of an Australian citizenship as a category of social identity is strikingly new. His comment marks the evolving divide between imperial sentiments and national aspirations. Prior to this Act, all Australian residents were British subjects - with the exception of the Indigenous population.

Representations both direct and reflect meanings of 'who we are' and 'who we are not' and even further, 'who we oppose'. The 
development of representations is dependent on communication. They are the subjects of public discourse and as a consequence of these discussions, there are always multiple, competing images. In the case of Australia, it is hypothesized that representations of the European are formed in a triangle of definition and demarcation to the indigenous population within, the inhabitants of the surrounding Pacific region, and the Australians themselves. Lastly, representations and social order are correlated. In studying their development and change in time, it is possible to examine how traditional representations are overcome and with them the social orders that have stabilised them (Baberowski/ Kaelble/ Schriewer 2008:12).

'National identity' and 'national stereotyping' are inevitably part in the process of constructing images of the European person. Here is an example to illustrate my point: In September 1923 The Bulletin featured the full main-page cartoon The European Menagerie. On top of a vantage point stands a little boy representing Australia (as revealed by the lettering on his hat.) He observes the scene below with some curiosity: an ensemble of animals and birds, each a stereotypical symbol for a European nation, deliver each other fierce blows. The French tiger snaps at the tail of the German eagle, calmly observed by the British lion. While the Spanish bull is already wounded, the Italian frog is ready to jump at the Greek fly. 'Well, I guess, I got the best possie, after all' comments the Australian lad.

The cartoon illustrates that the war has shattered Australia's admiration for Europe. Now, Australia is taking the position of a detached observer of European power tussles. The fighting parties are separated safely from the outsider below in a menagerie. Interpreting the caricature, one could point out the following: Australia's self-image reflects both immaturity and a feeling of inferiority as evident in being depicted as a child. Nevertheless, in regard to the Others, it is the only human player in the game, which adds ideas of reason, common sense and morality compared to the pugnacity of the animal crowd. Interestingly, neither are all of the pictured players nations, for instance the Balkans, nor are all of the chosen animal icons commonly used as national stereotypes. Lastly, 
all of the depicted play a significant part in the struggle for power on the European landmass. Nations like Denmark, the Netherlands, Portugal or Switzerland are not represented.

As displayed, notions of the European are not simply a multiplication and repetition of national identities of individual societies on a higher level. 'European' is neither used as a synonym nor a substitute for a single specific nationality or a fixed sample of national identities. Rather, it is a fluid term with shifting meanings around a core of shared values and ideas, always depending on the context and the time in which it has been used. To put it in more general terms, the exact function and meaning of these images can only be studied in a certain context and time frame. Then it is possible to determine the kind and degree of otherness applied in defining oneself.

Hence, I will examine the press debate about the settlement of Tropical Australia. By way of detailing the rhetorical deployment and meaning of representations of the European within this context, I will discuss how and for what purposes social boundaries between different groups have been drawn in that particular context. Towards that end, material has been collected from two weekly magazines, The Bulletin and Smith's Weekly, both published throughout the 1920s.

\section{The (European) White Man in the Australian Tropics}

From the second half of the $19^{\text {th }}$ century, ideas about racial exclusiveness had quickly gained a foothold in Australia. The implementation of the White Australia Policy attracted overwhelming support throughout the country. However, the legal exclusion of non-Europeans was insufficient. Without scientific argument for racial exclusion and practical proof that the tropical areas could be settled the government would be unable to maintain the White Australia Policy in the face of international pressures. 

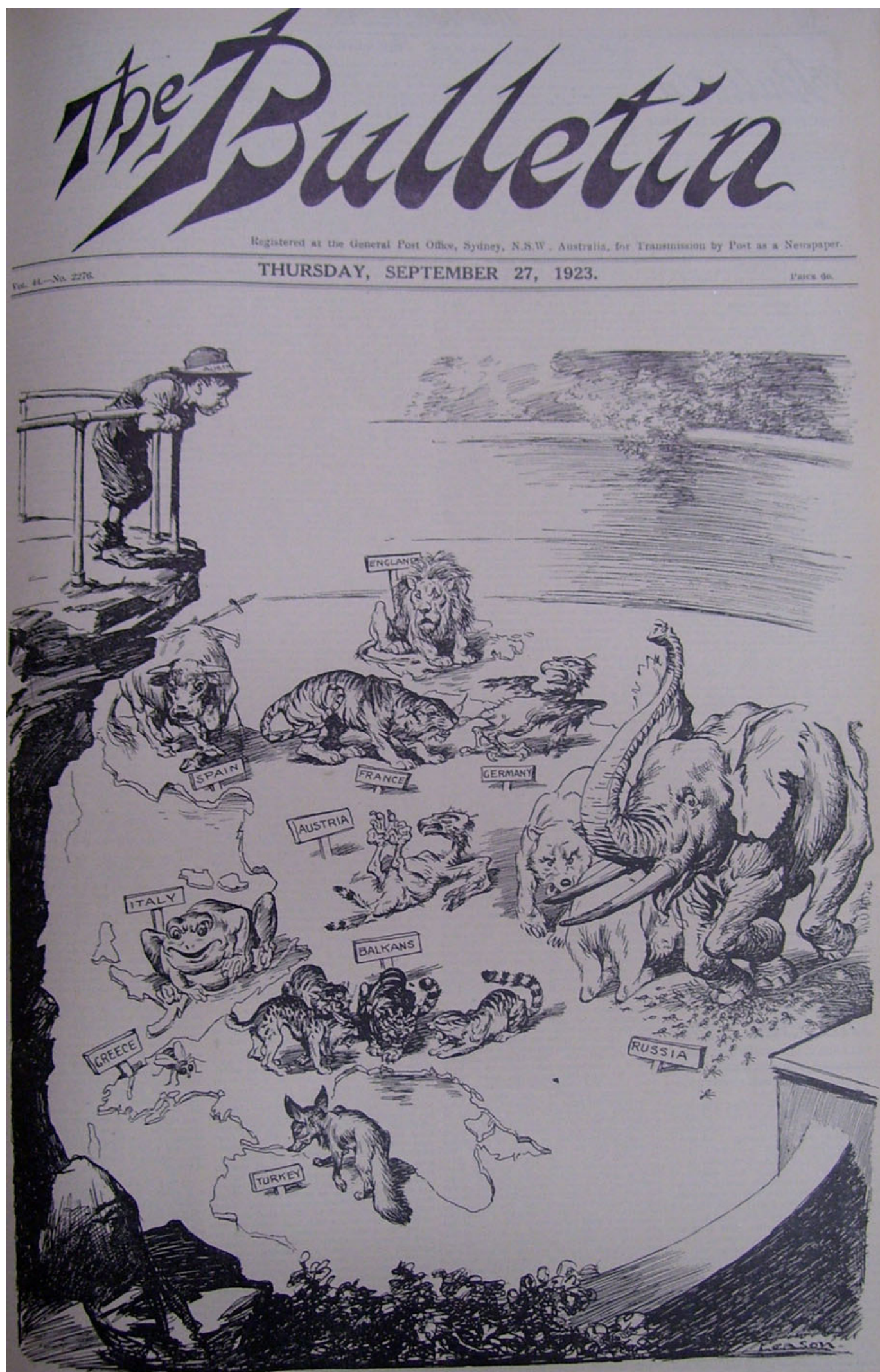

THT EUROPEAN MENAGERIE, 
From the beginning, Australian immigration restrictions were subject to British criticism as is evident in a 1921 newspaper article headed "White Australia as a Business Proposition":

Before the war, Downing-street was bitterly hostile to the employment of white men in any climate that could be called tropical. [...] In face of the 14,000 Europeans now engaged in sugarproduction up north, the 1907 dogma looks like ranking with the famous "infantry preferred" exordium of the S. African War or with the 1914 doctrine that Australian troops would be useless on the Flanders front.

At this point, 'European' is used as a term to emphasize a collectively shared cultural and racial background, directly related to the afore-mentioned 'white men'. The discourse of racial superiority pervades the entire article. The author supports a white employment monopoly in the Tropics. His focus is therefore upon the representation of the 'white body', evoking ideas of physical strength, endurance and morality despite a hostile climate. Adding the term 'European' serves as a label promoting solidarity. This is conspicuous in so far as a lot of Southern European immigrants were employed in the sugar industry in the tropics. Often, they were regarded as having the 'wrong colour' and as unwilling to assimilate into Australian society. A quota system was introduced (in 1924) that discriminated against Southern Europeans, favouring their Northern counterparts. In this example however, the inner-European differences are glossed over.

Creating a healthy white working population in the tropical parts of Queensland and the Northern Territory had been one of the main political and economic concerns at the time of Federation. An evergrowing fear of being taken over by land-hungry Asian nations responded to the growing power of Asia in world affairs. The press played a crucial role, stirring up resentment through circulating common stereotypes. To give an example: In the article "Five Years to Go: Startling Prophecy about the Northern Territory" (1925) which appeared in Smith's Weekly, the Japanese were depicted as sly and calculating, eager to take over 'unused land': 
But the Japanese continue to watch the Territory quietly. A high official states that their plans are known. They intend to make an issue in four or five years' time of Australia's neglect of the opportunity to develop the Territory and will claim the right of unrestricted admission.

The invasion narrative served as a disciplining tool to urge all Australians to meet their nation-building duties (Walker 2003:40). A denser settlement of the area was seen as an adequate measure to ensure that Australia could retain its territorial integrity.

In her study Imperial Hygiene (2004), Alison Bashford has stressed the deep connection between governmental rule and public health. At the beginning of the $20^{\text {th }}$ century, cleanliness, like military force, was seen as a way of taking control of a territory by medical means. Lines of hygiene were regarded as boundaries of rule and national influence. This explains the strong political commitment of the Australian government to claim control of these 'lines': to establish a national border bound by sea, to create a particular kind of society through immigration restrictions and by segregating Indigenous Australians, and to enforce sanitary measures to guarantee the productiveness of the 'white' population (Bashford 2004:1). In summary, tropical medicine played a crucial role in providing scientific knowledge on the viability of the 'project' of 'White Australia' despite hostile climate and tropical diseases.

1920 marked a turning point. A new generation of doctors and scientists, in particular the study group of the Australian Institute of Tropical Medicine, were successful in revising older medical concepts. Through extensive field study, climate theories were discredited and medical evidence provided that 'European Australians' would face no physical or mental damage when permanently settling the Tropics. The press reported about new medical findings in a positive light, since the medical remapping of tropical Australia underpinned the ideas of the White Australia Policy.

In January 1922 The Bulletin featured the article "Half-castes as a Substitute for Railways". The suggestion of Premier Barwell of South Australia to introduce coloured labour to develop the tropical 
regions, mainly the Northern Territory, had met vehement opposition. Based upon population data, the journalist, a firm supporter of the White Australia Policy, rather argued for the exclusion of non-whites and illiterate whites:

The census of 1911 showed that 572 out of every 1,000 inhabitants were not of European descent [...] (This of course does not include our aboriginal brother.) In addition the so-called Europeans of the Territory were under an unusual amount of suspicion, for the Turk and the Maltese and the whitish British subject [...] are to a great extent honorary Europeans. Out of a population of 3810 located on census day, 1422 read and wrote English; 918 read and wrote some other foreign language, and the rest left the painful subject alone. [...] What the place wants is a new deal and a turn of European civilisation.

Evidently, Europeans were regarded as the most desired inhabitants of the Northern Territory. The exclusivity of the term is enhanced by the specific appellation of the 'Maltese' and the 'Turk'. This is in contrast with other press articles of the time, arguing the position of Turkey and its inhabitants rather as part of the Orient. Similar to other immigrants from Southern Europe, Maltese were often regarded as 'semi-white', but also as reliable workers. Despite shared imperial ties, Maltese immigration to Australia had been prohibited after the Great War. However, Australia was unable to withstand the pressure of the British imperial authorities and immigration resumed. The development of Australia depended on (skilled) labour. Thus, hard-working, healthy (and literate) people were welcomed, as is demonstrated in this quote that labelled both immigrant groups as 'honorary Europeans'. Additionally, it is significant that the term 'British subject' was preceded by the adjective 'white'. The implication of this detailed explanation is that to be 'British' did not equal 'of white colour'. In the light of the historical context, all members of the Commonwealth were considered 'British subjects', for instance Indians, who were seen as a threat to mono-cultural Australia.

Returning to the aforementioned article in The Bulletin, the sentence in brackets almost goes unnoticed. The Indigenous peoples of Australia are herein described as "aboriginal brother", excluded and generalised as one extra group neither belonging to the ('white') 
Australians nor the immigrants. Although the use of the term 'brother' proposes a friendly relation, what is uppermost in the journalist's mind is that they pose no threat. Their invisibility in the statistics signifies that they are neither regarded a significant part in the future of Australia nor are they given the opportunity to become one. Unfortunately, this is not an isolated attitude. Derogatory stereotyping of Indigenous peoples was common in most of the Australian newspapers of the time. Often, they were depicted as dark-skinned, thick-lipped men and women, referred to as 'Jacky' or 'Mary', barefoot and dressed in rags. Alcoholism was regarded as one of the major problems among the Indigenous population and presented as a cause for laziness and lack of education, as pictured in the caricature "Dry Gin" (1922) by A.S. Petersen in Smith's Weekly. In summary, these references reflect that in the process of developing self-images and forming collective (cultural) identities as ('white') Australians, the Indigenous peoples of Australia were regarded as one significant Other.

Despite criticizing the governmental incompetence in developing the North especially in regard to a better railway system, the press was in line with the opinion of the younger generation of medical scientists supporting the idea of permanent settlement. However, there was general agreement that this would require better living conditions, such as adequate housing, clothing and health promotion. In "Barbarous Housing in the Tropics" (1926), an anonymous journalist referred to research undertaken by Dr. Cilento of the Australian Institute of Tropical Medicine: houses were too small, lacked lining and floors; running water was not always available; water tanks lacked screening from mosquitoes. The Labor government of the day were blamed for this health risk.

Thus, 'white' citizens lacked the preconditions to follow the obligations of medical doctors. As journalist 'Brinjal' points out in "Tropical Australia and the Medical Congress" (1920), "ordinary rules of modern health-protection (therefore needed to be) observed"" and their strict observance was to be supervised: 
If Australia will not wake up and make a real effort to develop her tropics, she will lose them and with them her nationality. [...] Tropical Australia means hard work and real work [...] say an additional ten thousand families [...] These should be Australian families for choice, or failing sufficient of these, Anglo-Saxon stock. Darwin affords a conclusive demonstration of the undesirability of importing the more savage European tribes to a white man's country.

Here, the author is very specific about the racial background of the desired immigrants. Elaborating on the issue of differentiation among Europeans, I will compare two visual depictions in the printed press. The first is the cartoon 'Nursery Rhymes for Modern Times' by Tom Glover, printed in January 1925 in The Bulletin: At a landing jetty, Australia (represented as either young lad or older man - the facial features are not precise) miserably awaits the arrival of a ship full of Southern European immigrants. Repulsion is expressed in the irony of the adapted nursery rhyme underneath as well as the intemperate language, referring to 'foreigners', 'foreign influx' and 'alarming proportions'. The facial features of the perceived aliens enhance the negative reception; their gazes are grim and determined. Interestingly, a comparable cartoon by Finey was published in the same month in Smith's Weekly. Southern European immigrants, specifically Yugoslavs, were portrayed in the same degrading way in "Another Dirt Plague". The cartoon has turned them into rats that leave the anchored ship in an Australian port balancing along a rope that is marked with a sign "Better immigration laws". The aim of both images was to foster a negative attitude to immigration from Southern Europe among the readership. While supporters of White Australia stressed racial differences and the belief in the inferiority of non-whites, the negative attitude to Southern European immigrants was officially defended by cultural differences.

As the environmental obstacles of settling tropical Australia were removed by new scientific findings, the focus shifted towards questions of public health. Unsanitary ways of living needed to be eradicated to decrease the prevailing dangers of disease and thus to remove the last obstacles for White Australia. While formerly being a part of an environmental discourse, proving that the 'coloured' man 


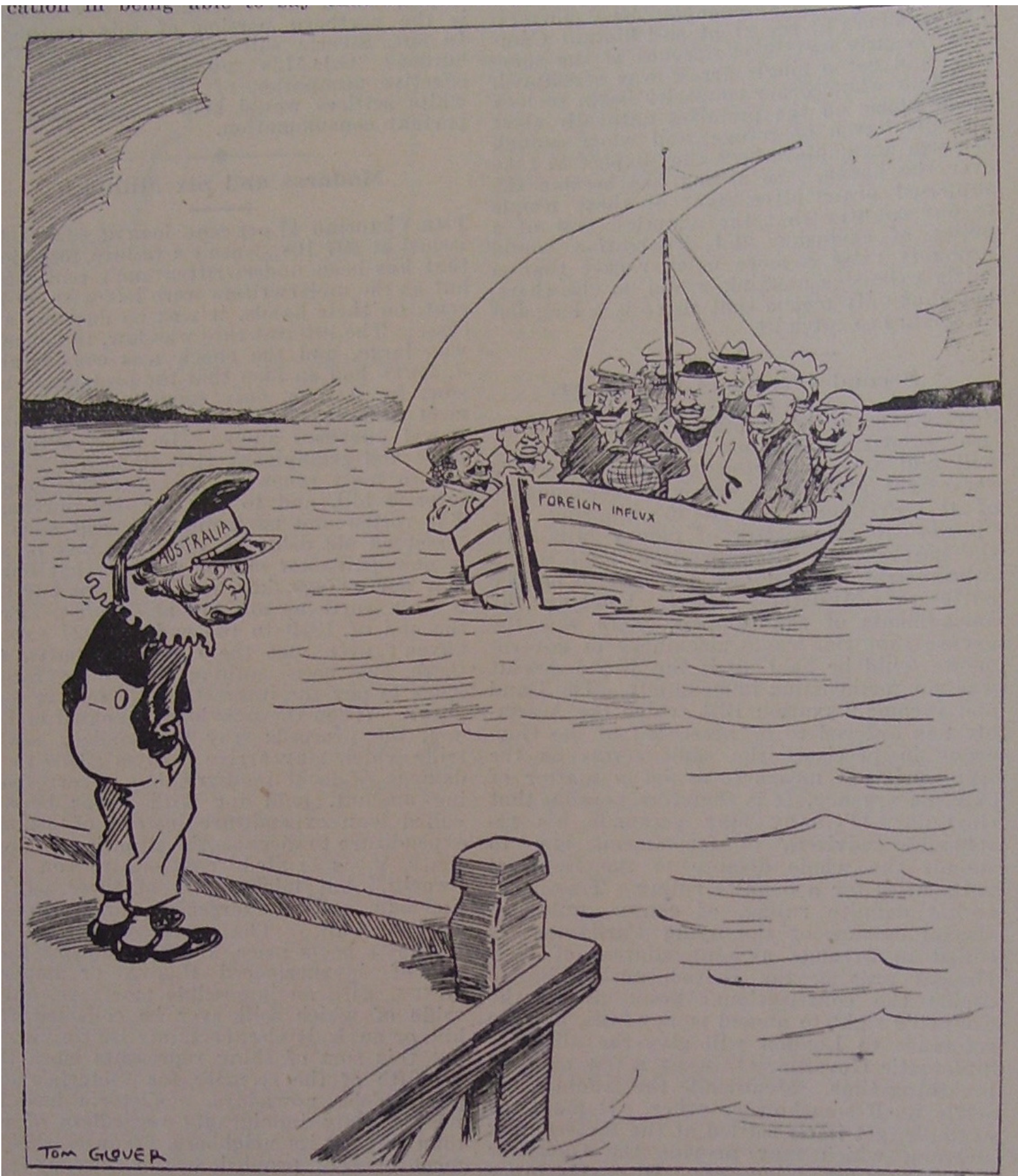

NURSERY RHYMES EOR MODERN TIUES.

"The influx of foreigners to Australia is reaching alarming proportions. During the quarter ended September 30, 1148 . Italians, 561 Greeks, and 417 Jugo-Slavs, to choose only three nationalities, entered the Commonwealth."

\section{"I saw a ship a-sailing, \\ A-sailing o'er the sea: \\ And, oh, it's deeply laden \\ With PRETTY things for me!"}

Tom Glover (1925), Nursery Rhymes for Modern Times, in: The Bulletin, 8 January 1925 , vol. 46, no. 2343, p. 12.

had no physiological advantage over the 'white' man in settling the area, medicine now became a significant element in the discourse of citizenship. 
In summary, the analysis of notions of the European within the press debate on Tropical Australia illustrates that representations of the European were utilised to mark out a distinct cultural background. Naturally, the reference 'European' held a positive connotation, in the sense of being civilised, educated, moral and of 'white skin colour', which were the preferred characteristics for ('white') Australian citizenship. Europeans were regarded as the most desired immigrants and hence also as inhabitants for the tropical areas. Often, the ascription would appear beside other categorisations such as 'white' and 'British' as well as in demarcation to 'native' and 'coloured'. In short, media representations of the European also indicated a shared racial background.

This is even more apparent with the demarcation line running between Northern and Southern Europeans. The latter were not sufficiently 'white'. Later, this differentiation would be replaced by a demarcation between Eastern and Western Europeans in regard to political changes in Europe.

\section{Conclusion}

As is evident in the Australian case study, identity and alterity are intertwined; the Self is dependent on Others. Negotiations about who was considered European for what reasons also took place outside Europe. To follow these processes of definition and constant re-invention of representations, for example in the printed press, reveals mutual, trans-national interrelations between different players. Further, this research provides infor mation on context and purposes in which these notions have been used and how they have been altered in regard to changes in political issues or shifts in belief systems. In short, the construction of the European person via images in the Australian media is a complex process, inevitably connected with historical narratives of the formation and implementation of Australian cultural (and national) identities. 


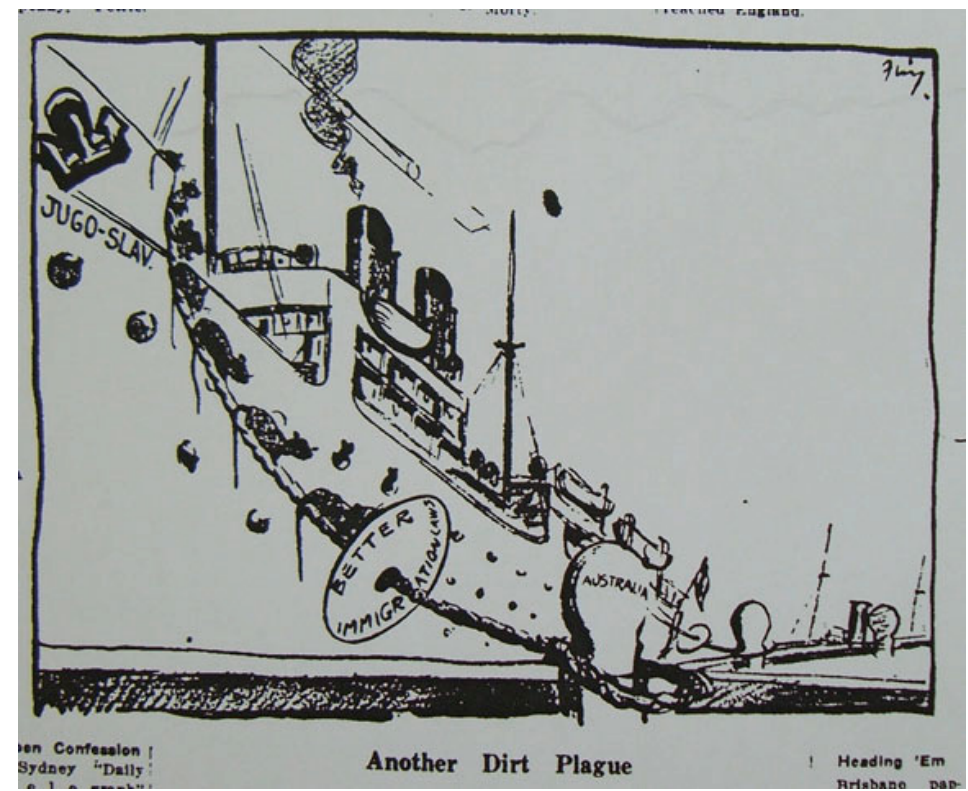

Finey (1925), Another Dirt Plague, in: Smith's Weekly, 31 January 1925, no. 50, p. 14.

The world is constantly holding up an inescapable mirror for us, reflecting images of who we think we are, but hiding what others think of us. Questions of identity are difficult to answer, for the past and the present. I recall the following episode during my first research trip to Australia in 2007, which might illustrate this difficulty: On an autumn afternoon in Canberra, I was invited on a stroll through the Botanical Garden. While driving there with an Australian lady in her fifties whose parents had migrated from the Netherlands in the 1950s before she and her siblings had been born, she raised her concerns about the travel plans of her nephew. Together with his friends, he intended to take the risky and highly physically demanding hike along the Kokoda Trail in Papua - New Guinea. "What was she worried about" I asked. She explained she had been on the island herself to do missionary work, and she knew about the dangers of malaria and other tropical diseases. In an exasperated voice she concluded: "We Europeans are just not made to cope well in these tropical areas!"

\section{Bibliography}

Baberowski, Jörg/ Kaelble, Hartmut/ Schriewer, Jürgen (2008), Selbstbilder und Fremdbilder: Repräsentation sozialer Ordnungen im Wandel (Frankfurt am Main: Campus).

Bashford, Alison (2004), Imperial Hygiene: A Critical History of Colonialism, Nationalism, and Public Health (New York: Palgrave). 
Bluche, Lorraine/ Patel, Kiran/ Lipphardt, Veronika (2009), Der Europäer ein Konstrukt. Wissensbestände, Diskurse, Praktiken (Göttingen: Wallstein Verlag).

Rudd, Kevin (2008), "Speech: A Change of Climate - A New Approach to Australia-Europe Relations," http://www.pm.gov.au/media/ Speech/2008/speech_0162.cfm, 5 May 2009.

Schmale, Wolfgang (2001), Die Konstruktion des Homo Europaeus, Comparative European History Review, vol. 1, pp. 165-184.

Spencer, Steve (2006), Race and Ethnicity: Culture, Identity, and Representation (Abingdon and New York: Routledge).

Tavan, Gwenda (2005), The Long, Slow Death of White Australia (Melbourne: Scribe).

Walker, David (2003), 'Race Building and the Disciplining of White Australia', in David Walker, Janice Gothard, and Laksiri Jayasuriya (eds.), Legacies of White Australia: Race, Culture and Nation (Crawley, WA: University of Western Australia Press), 33-50.

\section{Primary sources:}

'Barbarous Housing in the Tropics', The Bulletin, 15 April 1926, vol.47, no. 2409 , p. 11.

'Five Years to Go: Startling Prophecy about the Northern Territory', Smith's Weekly, 7 February 1925, vol. VI, no. 51, p. 11.

'Half-Castes as a Substitute for Railways', The Bulletin, 19 January 1922, vol. 43, no. 2188 , p. 7.

'White Australia as a Business Proposition', The Bulletin, 10 February 1921, vol. 42, no. 2139 , p. 7.

Bedford, Randolph (1920), 'Immigration', The Bulletin, 11 March 1920 , vol. 41 , no. 2091 , p. 7.

'Brinjal' (1920), 'Tropical Australia and the Medical Congress', The Bulletin, 16 September 1920, vol. 41, no. 2118, p. 7.

Finey (1925), 'Another Dirt Plague', Smith's Weekly, 31 January 1925, vol. $\mathrm{V}$, no. $50, \mathrm{p} .14$

Glover, Tom (1925), 'Nursery Rhymes for Modern Times', The Bulletin, 8 January 1925, vol. 46, no. 2343, p. 12.

Leason (1923), 'The European Menagerie', The Bulletin, 27 September 1923, vol. 44, no. 2276, cover page.

Petersen, A.S. (1922), 'Dry Gin', Smith's Weekly, 16 December 1922, vol. III, no. 43, p. 13. 


\title{
Oliver Haag
}

The Power of Form: Indigenous Australian Autobiography, the Rewriting of History, and the Fiction/Non-Fiction Divide

\begin{abstract}
A ccording to a statistical report, the autobiography stands among the most frequent literary genres of published Indigenous Australian literature (Cooper et al.: 11). Indigenous autobiographies have indeed increased in the Australian market since the Bicentenary of British settlement in 1988, with well over 177 book publications produced (Haag). Different theories have been canvassed about the possible reasons underlying the proliferation of published Indigenous autobiographies and literature in general, including changes in funding policies, the nexus between publications and broader inter-national events, the vested economic interest of publishing houses, and the success of Sally Morgan's bestseller My Place (1987), which has spawned subsequent publications in the very genre (e.g., Brewster: 7; Shoemaker: 75; Muecke; Haag: 8-9).
\end{abstract}

Quite another reason, I contend, lies in the genre of the autobiography itself. ${ }^{1}$ The autobiography is, after all, an ideal form through which to convey history-a motive that characterises most Indigenous autobiographies. The common assignation of autobiography to non-fictional forms further corroborates the conveyance of history. Thus, I put forward the theory that published Indigenous autobiographies flourished at particular points in time when the needs for publicising historical experiences coincided with demands for seemingly authentic Indigenous histories. They have also flourished because Indigenous autobiographies are published in a non-fictional genre that allows the establishment of an immediate alliance between personal experiences and (truthful/authentic) history.

\footnotetext{
${ }^{1}$ Scholarly writing on autobiographical theory is distinguished by a great complexity. Key texts are Olney; Smith and Watson; Lejeune.
} 
56ISeite Oliver $\mathrm{Hag}$

The present article examines the fiction/non-fiction divide from the perspective of (specialist) readers of Indigenous autobiographies. Based on a range of interviews ${ }^{2}$ conducted with Indigenous and nonIndigenous researchers-authors included-it poses the question of whether the differentiation between fictional and non-fictional genres plays a role in designating Indigenous autobiographies as historical documents. Does the differentiation influence the ways in which the autobiographies are received? Does it affect the perceived truth of the work? This question has two underlying considerations. First, the difference between fictional and non-fictional classifications allows an examination of the relevance of the truth effects of genres, and, thereby, also allows one to ask whether the genre classification was decisive in determining history and truth, respectively. The second consideration is to identify possible underlying meanings, both in interweaving truth with fiction and also in adopting fictional genres to counteract historical narratives.

\section{History and Truth in Indigenous Autobiography}

History forms an important theme in Indigenous autobiography. In scholarly analyses, Indigenous autobiographies are often classified as Indigenous modes of history (e.g., Attwood: 123; McGrath: 373). Moreover, many authors themselves emphasise the historical value their stories bear. In Sally Morgan's My Place (1987), Arthur Corunna says: "It's history, that's what it is. We're talkin' history" (163). In a similar fashion, Alice Nannup concludes, "I had to tell those things because they are the truth and part of doing this is the hope that all people, young, old, black, white, will read this book and see how life was for people in my time" (217-218).

The genre of the autobiography is crucial in this respect because it is germane to history. Loosely defined, both genres are concerned with incidents that happened in the past. Conversely, Indigenous modes of history are close to what in a loose sense can be termed autobiography. Lyndall Ryan captures some characteristics of (published) Indigenous Australian history: the motivation to testify

\footnotetext{
${ }^{2}$ I conducted 22 qualitative in-depth interviews with researchers in the areas of Indigenous Studies, History, and Literary Studies; all respondents are specialised in Indigenous literature, autobiography, and/or history. This also includes authors of autobiographies and fiction.
} 
to Indigenous survival, the distinctive forms of Indigenous style and humour, the absence of bitterness, the centrality of the author, and the idea that the historian was part of the history (56-57). In short, the autobiographical genre is a constitutive part of what has come to be called Indigenous history. This form of history is based on the memory of personal experiences, sometimes reaching back over many generations and thus relating to wider historical contexts that involve the family and community. As Isabel McBryde remarks, "[t]o Aboriginal people, a history that is grounded in personal and family histories or accounts of familiar territory (country) has primacy" (12). Put another way, Indigenous history is derived from both an autobiographical and a local background, with personal experiences as the basis of historical accounts.

Furthermore, many authors stress not merely the historical value but also the veracity of their stories: "I speak the truth and I speak of what I know" (McKellar 167). Similarly, Della Walker insists that "[t]his story, it's true. It's not made up what I'm telling you in this book" (14). Quite separate from such explicit remarks, some autobiographies also contain a multitude of cross-references ranging from file extracts to police records, and citation of secondary literature (e.g., Huggins and Huggins 34-35, 49-50, 53-54; Hegarty 111).

One of the most telling examples in this respect is a booklet by Marjorie Woodrow entitled One of the Lost Generation (1990). This self-published and seldom-cited autobiography contains 60 printed pages, $65 \%$ of them consisting of mere file extracts and historic letters. ${ }^{3}$ Such overwhelming trust in archival verity indicates the high value attached to truth. After all, in light of the History Wars, in which the violent moments in inter-racial Australian history have been severely downplayed, truth has become a prevailing issue. When asked about the reasons behind inserting file extracts in her mother's biography, Jackie Huggins in her interview confirms the relevance of truth:

\footnotetext{
${ }^{3}$ Pages written by the author $\Sigma=21$; (pp.5-6, 11-26, 57-59); the rest $(\Sigma=39)$ consists of files.
} 
It was an artefact for presenting the truth or an evidence of historical reference. [. . .] And it's good when you have those things because they're there in black and white. How can you change a signature or a date from 1908? (Personal interview, 18 Aug. 2004)

Truth is an essential component within the context of Indigenous autobiography. Much of this importance relates to the truth of the genre, more precisely, the 'truth effect' that emanate from a genre. Though truth is not part of the literary definitions of autobiographyit is usually defined as a text in which the names of the author, the narrator, and the protagonist match (Lejeune 26)-autobiography is nevertheless married to truth, especially when reading strategies are taken into account. As Margaret McDonell states, "readers' perceptions of truthfulness and authenticity are integral to the acceptance of autobiographic writing." (60).

These commentators recognize that readers have considerable expectations regarding the veracity of autobiographical accounts. Simmering debates over hoaxes or presumable falsehoods are a reliable indication of this hypothesis. For example, such a debate erupted when Leon Carmen, a white taxi-driver, was exposed as having published the autobiography of 'Wanda Koolmatrie, a Pitjantjantara woman' who, as must be added, had never existed.

Furthermore, from the authors' standpoint, the aura of truth in nonfictional genres serves to underpin veracity. Put simply, the history (re)writing author gains credibility by choosing a non-fictional over a fictional genre. Although history conveyed through fictional genres is not necessarily false (White 1987), readers can easily dissociate themselves from accounts they believe unreal. Some scholars have indeed advanced the argument that Indigenous authors favoured the autobiography because of the truth assumption that enabled the conveyance of personal experiences and witnessing (e.g., Watson 125-126, 193-194; Westphalen 96).

\section{The Fiction/Non-Fiction Divide}

History and truth are seen as being important to Indigenous authors. This importance might enhance the relevance of non-fictional genres because non-fiction is broadly associated with stories that rely on 
verifiable facts and thus, historical truthfulness. More precisely, one is led to assume that if Indigenous authors intended to write history, they would choose a non-fictional genre. As already outlined above, some scholars have indeed proposed such theories, assuming that Indigenous authors chose to write in the autobiographical genre precisely because of the perceived truth of the genre. Yet, though this presumption may sound logical, it is not always true empirically, particularly with younger and emerging authors. As Melissa Lucashenko says:

I call my books novels. Certainly, they are novels with a strong historical flavour. [. . . I I would agree that what I do in my books is rewriting history-if not rewriting, then at least complementing or establishing history and providing an alternative voice or alternative viewpoint. (Personal interview, 17 Aug. 2004)

Another Indigenous author I consulted prefers to write in the genre of historical fiction in order to address a younger readership:

My novel is in the genre of historical fiction; the characters are created, but also I had to sign a contract with the publisher saying that all the facts, all the dates and policy and everything was historically accurate. That it has all been researched by whitefellas. The reason for doing it in that format-the historical novel as a journal-was so that young people, who aren't going to read an academic text, can actually learn about the significant moment in Australian history. (Anita Heiss, Personal interview, 12 Aug. 2004)

In her published dissertation Dhuuluu-Yala (2003), Heiss goes even further, arguing that the rewriting of Australian history was inherent to all genres of Indigenous literature (36), thus somehow suggesting that genre plays no role in reading Indigenous literature with regard to its historical contents.

What is more, this ambiguous picture of genre classification of Indigenous autobiographies also applies to scholarship in which Indigenous autobiographies are-at least in some quarterscategorised as fiction and/or novels. Carole Ferrier has written the most technical theoretic text on the reasons for calling Indigenous autobiographies 'novels'. The author's aim is to include Indigenous autobiographies in literature courses, in order to analyse literary 
60ISeite Oliver Hag

aspects such as language and style (Ferrier 201-202). However, Ferrier does not relate her genre assignation to historical truthIndigenous novels were, as her text suggests, no less truthful than autobiographical/non-fictional texts.

Other scholars, too, employ the term 'novel' (without defining it) for particular Indigenous autobiographies. For instance, Sonja Kurtzer, without making explicit the reasons for her genre choice, terms Glenyse Ward's autobiography Wandering Girl (1987) a 'novel' (183), just as Stephen Muecke considers My Place (1987) a novel (1988). Yet given that Indigenous autobiographies are suffused with history, how does this suffusion then square with a fictional genre like the novel? After all, the novel has, at least to historians, a weak status as a format for conveying history. This does not mean that one should consider autobiography and history as truthful per se. Autobiography and history are in a sense fictional as they are narratives of the past. However, non-fiction is nonetheless perceived as historically more accurate not just because it is verifiable. This belief may also apply to common readers, for reminiscences written entirely in a fictional genre are usually not recognised as truthful and historical, let alone eligible for the rewriting of history. Significantly, the frequently heated debates arising over presumable hoaxes testify to the nexus between non-fiction and veracity (Egan 2004).

Considering that Indigenous autobiographies are also described as novels and thus as fictional, and that Indigenous literature is always an attempt to re-write (white) history, the question becomes whether the distinction between fictional and non-fictional genres is important in reading Indigenous autobiographies as historical documents. Does it, in such context, make a difference if the Indigenous autobiography is classified as a fictional genre? I always confronted my interviewees with one particular question: 'Why or why not is it important to differentiate between fictional and nonfictional genres in Indigenous autobiographical writing?' I hasten to add at this point that I did not make 'truth' or 'history' explicit in my question and never mentioned either word in conjunction with it. 
The reason for asking this particular question is to verify the relevance of the truth of the genre when reading Indigenous autobiographies as historical texts. After all, genre is not merely a literary category defined by scholars for scholars, but also a form of interaction between reader and author, thus "a specific type of artistic or cultural composition, identified by codes which the audience recognize" (Anderson 136). While this study has its focus on a scholarly audience-an empirical study of common readers would probably yield different results-it nonetheless gives a graphic picture of the importance of non-fiction/fiction categories in reading Indigenous autobiographies as historical documents. Thus, here I am not merely interested in the motivations of authors to employ fictional or non-fictional genres when communicating history, but also in readers' perceptions of Indigenous autobiographies as historical texts.

The interviews indeed show significant differences between authors and readers. While some authors think it important to write in nonfictional genres when conveying their historical experiences, the bulk of them do not deem the genre classification important in this respect. For example, Ruby Langford Ginibi, author of several autobiographies, perceives non-fictional genres as truthful per se. She was very emphatic about this issue when I asked her whether it was important to differentiate between fictional and non-fictional forms:

No, it's not a novel; it's the truth. Because it is the truth. And I mean everybody that I wrote about in my books has walked back in my life, those that are still alive. But it is truth and it is history. It is a rewriting of history to get the acknowledgement for our people. (Personal interview, 18 Sep. 2004)

To this author, the genre choice was absolutely crucial to imparting an Indigenous counter-history. Put another way, the author opted for the autobiographical genre for it is a) non-fictional and thus b) provides the possibility of telling a truthful history. Jackie Huggins, in turn, answered my question with reference to her mother's initial efforts to withhold certain phases of her life; Huggins is co-author of her mother's dialogically narrated biography Auntie Rita (1994)-to 
62ISeite Oliver Hag

her, the differentiations between fiction and non-fiction are imperative:

There is an element of fiction and non-fiction that I know is in the book [. . .]. I must say that, and I admit this, that historically there were just some parts where I've questioned, 'did this actually happen?' The editor picked up that there was a seven-year gap in the story line. And she said, 'what did your Mother do; where did she go?' And Mum had never ever told me that story [. . . ; it had been such a shameful thing. (Personal interview, 18 Aug. 2004)

Thus, the truth of the genre has, in the latter two instances, indeed a bearing on the decision to write an autobiography or biography. These examples consequently lend support to the arguments deployed in scholarship that Indigenous authors prefer the autobiography because of the truth of the genre. However, as the intrusion of the shame factor already suggests, this cannot be generalised. The aversion to confessing shameful and painful incidents, particularly on the part of elderly Indigenous persons, has been documented in scholarly literature. Different theories have been proposed for such reticence. It has been explained as a deliberate resistance to information and representation politics (Gelder 362). Other reasons include the reluctance to speak about events perceived as shameful, and the circumstance of there being restricted cultural information not destined for the public gaze (Cowlishaw 185-189). The latter means that culturally sensitive issues, such as genderbased work or sexuality, should not be shared between the generations and sexes, both within and outside the family. The difficulty in revealing the truth bears relevance for the genre itself. Alexis Wright turns the assumed correlation between non-fiction and truth on its head, saying:

Fiction is a better way of telling the truth. [. . .] There are a lot of people of our mothers' generation, the older people of the communities, who have gone through terrible times. [. . .] How can you find a way to disclose these experiences-which means to expose these people-in a non-fiction form? (Ravenscroft 75-76)

Thus, to some authors, non-fictional genres are a difficulty, rather than a trigger, to imparting history. Trauma and shame are grave 
reasons which render non-fictional genres too 'hurtful' and/or immediate for telling personally experienced history.

Other Indigenous writers that were also interviewed consider the need to differentiate between fiction and non-fiction of low importance. Melissa Lucashenko, a novelist, remarks:

Is it important to distinguish? For me, no. Not really. I mean in my writing I wouldn't invent a scenario that either hadn't happened or that I didn't think could have easily happened. I think that's pretty true of all Aboriginal women writers that I know. We are not setting out to fabricate some kind of history or some kind of contemporary society. We write from what we know. (Personal interview, 17 Aug. 2004)

Though not considering distinctions between fiction and non-fiction essential, the respondent nonetheless attaches great significance to truth. This is similar to Anita Heiss, author of fiction, who regards the differentiation between fiction and non-fiction as yet another categorisation serving the purpose of academy, publishers, and booksellers. By way of contrast, Indigenous authors had to fulfil the urgent task of reclaiming history:

Whether it's theatre, or poetry, or autobiography, or fiction, all our books have common themes of survival, oppression, the ongoing cultural genocide of one government after the next. You know, it tends to maintain or reclaim identity and language. So it doesn't even matter what genre it's in, most our writers are doing the same things in different formats. (Personal interview, 12 Aug. 2004)

The differentiation between particular genres does not seem to matter to most Indigenous authors. How then do their opinions relate to readers' perceptions?

The interviews with readers yield the following results. Most respondents demand a differentiation between fictional and nonfictional genres. This is glaringly evident in those cases where Indigenous autobiographies are read for their historical value. And significantly, most respondents read Indigenous autobiographies as bearing historical information. Melbourne-based historian Bain Attwood, for one, strictly distinguishes between history and fiction, 
as well as between autobiography and fiction. He refers to a debate as to whether Sally Morgan had invented that Howden DrakeBrockman had committed incest with her grandmother. Assuming that the incest might be fabricated, Attwood argues to consider $M y$ Place no longer an autobiography but a novel:

[W]e should remind ourselves that in My Place there is a claim there about incest [. . .]. So I would read Sally Morgan's book as a novel these days. I wouldn't read it as autobiography. And I suspect the incest claim is part of its characteristics as a novel. (Personal interview, 02 Aug. 2004)

The autobiography here is associated with a factually grounded, that is, true story, and, contrariwise, fiction with a story that is incorrect. This reader clearly expects an (Indigenous) autobiography to be factually truthful. Linda Westphalen, author of a doctoral thesis on Indigenous women's autobiographies, is also reluctant to perceive Indigenous autobiographies as fictional; more so, she conceives them as histories in their own right:

I count Indigenous life histories as being knowledge production about the past. I don't want to call them anything that associates them with fiction, because that then undermines the story. That makes it seem like they are not telling us the truth when, in fact, what they are doing is, for me, opening up a whole area of Australian history that I know very little about, apart from what they tell me. (Personal interview, 09 Aug. 2004)

Tim Rowse, a scholar specialising in Australian and US Indigenous autobiographies, also distinguishes between fictional and nonfictional forms. He considers the differentiations between nonfictional and fictional genres imperative, not least of all because, in the public gaze, truth claims have to stand up to factual verification:

I think it's very important to make this distinction between fiction and non-fiction. That is, in the public sphere, truth claims are important and there are recognized ways of testing truth claims. [...] I think there has to be some factual basis to an autobiography. (Personal interview, 02 Sep. 2004) 
In quite a similar way, historian Peter Read does not consider fictional writings as historical, since fictional accounts are less accurate and reliable than facts:

Archie Weller is a wonderful writer but you can't exactly use that as evidence of history in Western Australia. Of course you can't; you can say, Archie Weller describes it as that and there is other confirming evidence that the police acted in that sort of way. But that is not to say it's nearly so powerful for us historians as somebody who is saying, 'this is what actually happened to me and there is Mister Neville, and this was the year and this was what happened.' (Personal interview, 13 Aug. 2004)

Lastly, Stephen Muecke differentiates between fiction and history, with the latter being distinguished by real facts:

I am not going to use the word history if these works are fairly fictional. Sometimes it's clear from the techniques of the writing that it's fictional and even autobiographies and histories also use fictional techniques and are selective in what they write about [. . .] Histories are closely linked to a factual basis and they include more dates, they include specifics about time and place, they include the real names of the protagonists. (Personal interview, 12 Sep. 2004)

As these answers show, there is a strong demand to differentiate between fiction and non-fiction and to assign genre an important role when reading Indigenous autobiography as historical texts. Significantly, most respondents fall into this category. Yet much depends on what expectations readers bring to a text-if Indigenous histories are read as historical texts, which becomes evident in the interview results, the fiction/non-fiction genre divide does occupy a crucial footing. Thus, even while some authors may write in fictional forms and still wish to convey history (or even deliberately adopt fictional forms to convey history), this alliance does not seem to be evident with readers.

Yet it seems worth noting that truth compels great attention, even from those (few) respondents who do not deem the fiction/nonfiction genre divide important in reading Indigenous autobiographies as histories. Truth is thus held in great esteem, even in the case of fictional formats. However, there are two 'groups' of respondents who approach truth in different ways: one who does not relate the 
question of truth to the attribution of genre, with some interviewees regarding fiction as just another-perhaps more artistic and flexibleway to tell the truth about Australia's past. The other (and numerically greater) group attributes the question of truth (also) to genre.

Another even more remarkable feature of the responses is that two different themes have been discussed. First, though they were never asked explicitly about truth, but rather for the necessity to differentiate between fictional and non-fictional genres, the respondents identified truth as a central theme of their own accord. This phenomenon lends empirically-grounded support to the supposition that the truth of the genre is decisive in reading Indigenous literature as historical texts.

Second, the discourse on truth falls into two different yet sometimes conflated strands. One is the truth of the story, which includes the accuracy of the facts and contents; the other is the truth of the genre. Though genre alone is not a reliable indicator by which to assess historical truth, there is an indication that the classification carries considerable weight with readers. The perceived truth of the genre has a considerable bearing on the reading of Indigenous autobiographies as historical documents. The correlation between non-fictional genre choice and Indigenous history writing suggested in scholarship on Indigenous Australian autobiography must thus be slightly revised: this correlation applies to readers rather than to Indigenous authors.

This different perception of genre between authors and readers has important consequences. As this study has shown, genre is the first and crucial form of interaction between the author and the reader. The intended message-that is, to convey history-runs the risk of being ignored or at least taken less seriously if Indigenous autobiographies are interpreted as fictional.

What is more, genre is not merely crucial in reading Indigenous autobiographies as historical texts. I contend that it also plays a fundamental part in the proliferation of Indigenous autobiographies, 
for the autobiographical genre is appealing on grounds of its closeness to truth and history. This has to be understood in a broader context of what W.E.H. Stanner in the late 1960s famously called the 'Great Australian Silence', that is, the neglect of Indigenous history by Australian historians. Since the 1970s/80s, the increasing erosion of this silencing has resulted in an additional demand for Indigenous histories. The autobiography has been an ideal medium through which to narrate such histories, for it is close to the concepts of Indigenous history-telling, and, still more important, it suited audience expectations to read personal histories in a genre that promises truth.

This study has empirically proven the very nexus between genre and specialist readers' expectations. This nexus may only apply to scholarly readers in Australia. A further survey about common readers needs to be conducted in order to draw broader conclusions. Such a survey may probably yield similar results. As empirical studies of readers' behaviours have shown, the differentiation between fiction and non-fiction seems to be important to most readers (e.g. Mann 149-50). There is further evidence for this assumption: in Australia, historical truth in relation to inter-racial history has become an important and broadly contested issue. The debates on topics such as land rights, genocide or the History Wars are indicators for the stance of truth in Indigenous history in the broader non-academic domain. The discursive importance of truth may likely influence the reading of Indigenous autobiographies.

Furthermore, this nexus between genre and readers' expectations is reflected in the dustcover marketing of Indigenous autobiographies-most books are clearly advertised as truthful histories, some even explicitly. Publishers, in other words, sensed readers' demands for historical accounts, and thus concentrated on a genre that best suited these demands-the autobiography. However, such a nexus is, at the same time, place and time-specific: for instance, to overseas readers the issue of genre and truth are of different importance compared to settler Australians. Significantly, Sally Morgan's German edition of My Place (1987), Ich hörte den Vogel rufen (1991) bears the genre-specific subtitle 'novel', apparently 
because the dialogic structure of the book is unconventional for an autobiography. Thus, the German translation is not advertised in relation to historical truth.

In conclusion, the responses suggest that the question of genre is important in reading Indigenous autobiography. As has become apparent, many (scholarly) readers attach importance to the truth of the genre. The status of truth in the form of writing, that is, genre, has significant bearing on the text: genre does matter.

\section{References}

Anderson, Linda, 2001. Autobiography. London: Routledge.

Attwood, Bain, 1990. "Aborigines and Academic Historians: Some

Recent Encounters", Australian Historical Studies 24:94, 123-135.

Brewster, Anne, 1996. Reading Aboriginal Women's Autobiography.

South Melbourne: Sydney UP.

Cooper, Judi et al., 2000. To Tell My Story. A Study of Practising

Professional Indigenous Writers of Australia. Research Report.

Sydney: Australia Council for the Arts.

Cowlishaw, Gillian, 2006. "On "Getting it Wrong": Collateral Damage

in the History Wars". Australian Historical Studies 127, 181- 202.

Egan, Susanna, 2004. "The Company She Keeps: Demidenko and the

Problems of Imposture in Autobiography." Australian Literary

Studies 21:4, 14-27.

Ferrier, Carole, 1992. "Aboriginal Women's Narratives". In: Ferrier,

Carole, ed., Gender, Politics and Fiction. Twentieth Century

Australian Women's Novels. St Lucia: U of Queensland P, 200-218.

Gelder, Ken, 1991. "Aboriginal Narrative and Property". Meanjin 50, 353-365.

Haag, Oliver, 2008. "From the Margins to the Mainstream: Towards a

History of Published Indigenous Australian Autobiographies and

Biographies". In: Read, Peter et al. eds, Indigenous Biography and

Autobiography. Canberra: ANU-E P, 5-28.

Hegarty, Ruth, 1999. Is That You Ruthie? St Lucia: U of Queensland P

Huggins, Rita, and Huggins, Jackie, 1994. Auntie Rita. Canberra:

Aboriginal Studies $P$.

Kurtzer, Sonja, 2003. "Wandering Girl: Who Defines 'Authenticity' in

Aboriginal Literature?" In: Grossman, Michele, ed., Blacklines:

Contemporary Critical Writing by Indigenous Australians. Carlton:

Melbourne UP, 181-188.

Lejeune, Philippe, 1996. Le pacte autobiographique. Paris: Seuil.

McBryde, Isabel, 1996. "Perspectives of the Past: an Introduction."

In: Chapman, Valerie and Read, Peter, eds. Terrible Hard

Biscuits. A Reader in Aboriginal History. St Leonards: Allen \& Unwin, 1-15.

McDonell, Margaret, 2005. "Locating the Text: Genre and Indigenous Australian Women's Life Writing." Life Writing 2:2, 55-74. 
McKellar, Hazel, 2000. Woman from No Where. Hazel McKellar's Story. Broome: Magabala.

McGrath, Ann, 1995. "Contested Ground: What is 'Aboriginal History'?" In: McGrath, Ann, ed., Contested Ground. Australian Aborigines under the British Crown. Sydney: Allen \& Unwin, 359-399.

Mann, Peter, 1982. From Author to Reader. A Social Study of Books. London: Routledge.

Morgan, Sally, 1991. Ich hörte den Vogel rufen. Roman. Berlin: Orlanda Frauenverlag.

-. 2003. My Place. London: Virago.

Muecke, Stephen, 1988. "Aboriginal Literature and the Repressive Hypothesis." Southerly 48:4, 405-418.

Nannup, Alice et al., 1992. When the Pelican Laughed. Fremantle: Fremantle Arts Centre P.

Olney, James, ed., 1980. Autobiography. Essays Theoretical and Critical. Princeton: Princeton UP.

Ravenscroft, Alison, 1998. "Politics of Exposure. An Interview with Alexis Wright". Meridian 17:1, 75-80.

Shoemaker, Adam, 1995. "Does Paper Stay Put? The Politics of Indigenous Literature in Canada and Australia". In: van Toorn,

Penny and English, David, eds, Speaking Positions. Aboriginality, Gender and Ethnicity in Australian Cultural Studies. Melbourne: Department of Humanities, 73-89.

Smith, Sidonie, and Watson, Julia, 2001. Reading Autobiography. A Guide for Interpreting Life Narratives. Minneapolis: U of Minnesota P.

Walker, Della, and Coutts, Tina, 1989. Me and You. The Life Story of Della Walker. Canberra: Aboriginal Studies P.

Watson, Christine, 2001. "'My Own Eyes Witness': Australian Aboriginal Women's Autobiographical Narratives." PhD thesis, University of Queensland.

Westphalen, Linda, 2002. "Deadly Lives. Palimpsests in Aboriginal Women's Life-Histories'". PhD thesis, Flinders University.

White, Hayden, 1987. The Content of the Form. Narrative Discourse and Historical Representation. Baltimore: Johns Hopkins UP.

Woodrow, Marjorie, 1990. One of the Lost Generation. Narromine: Marjorie Woodrow. 
Martin Grosch:

Automobilabhängigkeit und verkehrsbedingte $\mathrm{CO}_{2}$-Emissionen in Sydney: Ursachen und Lösungsansätze

\section{Einleitung: Die Automobilabhängigkeit in Sydney - eine Folge des zweihundertjährigen flächenhaften Siedlungswachstums}

ie Stadtentwicklung in den australischen Metropolen ist von der Ankunft der weißen Siedler bis heute von einem starken Flächenverbrauch und einer niedrigen Bebauungsdichte gekennzeichnet. Fortschritte in der Fahrzeug- und Verkehrstechnologie begünstigten immer wieder den „Urban Sprawl".

Der Bau der Straßenbahn in Sydney im Jahr 1879 leitete zunächst eine sternförmige Ausbreitung der Vororte entlang der neuen Bahnlinien ein. Der "Siegeszug des Automobils" führte dann ab den 1960er Jahren zu einem Bedeutungsverlust des Öffentlichen Personennahverkehrs (ÖPNV) und letztlich zu einer kompletten Stilllegung des Straßenbahnverkehrs im Jahr 1961. Sydney entwickelte sich zu einer flächenhaften "Automobile City" (Forster, 2004: 18). Das Bevölkerungswachstum trug zur Entstehung vieler neuer Stadtteile bei, die aufgrund der flächenhaften Entwicklung und der daraus entstehenden großen Distanzen nicht mehr an das öffentliche Verkehrsnetz angegliedert waren.

Heute steht Sydney vor der Herausforderung, den ökologischen Problemen entgegenwirken zu müssen, welche aus der ausgeprägten Automobilabhängigkeit entstanden sind. Vor allem in Zusammenhang mit dem Klimawandel sind politische und planerische Akteure in Sydney gefordert, die urbane Mobilität umweltverträglicher zu gestalten. In diesem Beitrag sollen mit Hilfe von qualitativen und quantitativen Methoden Strategien und Lösungsansätze erarbeitet werden, welche zu einer Abschwächung der automobilbedingten Umweltbelastung beitragen können. 


\section{Die „compact city" als Lösungsansatz? Die Bedeutung von innerstädtischen Nachverdichtungsmaßnahmen in Sydney}

Das NSW Department of Planning schätzt das Bevölkerungswachstum in Sydney innerhalb der nächsten 25 Jahre auf 1,1 Millionen Menschen (NSW Department of Planning 2005:3). Dieser starke Bevölkerungsanstieg ermöglicht der Stadtplanung, die Grundlage für eine ökologisch nachhaltige Siedlungsstruktur zu legen. Für die Schaffung neuer Wohngebiete bieten sich bauliche Nachverdichtungsmaßnahmen an. Dieser Ansatz, der in Australien als "Urban Consolidation" bekannt ist, wurde bereits während der letzten 25 Jahre hauptsächlich in den Innenstädten der australischen Metropolen verfolgt, um die Bevölkerungsdichte zu erhöhen. In der Raumplanung verspricht man sich hiervon eine Abschwächung der Automobilabhängigkeit. Als bekannteste und umfassendste wissenschaftliche Untersuchung zu den Ursachen der Automobilabhängigkeit in Städten sei auf die Arbeit von Peter Newman und Jeff Kenworthy verwiesen (1999). Die beiden an der Murdoch University in Perth lehrenden Stadtforscher sammelten und erhoben weltweit in 46 Städten Daten zur PKW-Nutzung und zu Bebauungs-, Bevölkerungs- und Arbeitsplatzdichte, setzten diese in Beziehung und bestätigten damit ihre These einer steigenden Automobilabhängigkeit bei sinkender Bevölkerungsdichte (Newman, P. und J. Kenworthy 1999:94).

Am Beispiel von Sydney entwerfen sie den Vorschlag, Verdichtungsmaßnahmen nicht nur im Kerngebiet, sondern auch im Umkreis von suburbanen Stadtzentren wie Chatswood oder Parramatta zu forcieren. Diese "Town Centres" sollen untereinander mit öffentlichen Verkehrsmitteln erreichbar sein und in einem Radius von 10 bis $15 \mathrm{~km}$ als Einzugsgebiet für weitere, ebenfalls an den ÖPNV angebundene "Local Centres" dienen. Für Sydney ist also eine mehrkernige Stadtstruktur angedacht, in dessen Zentren ein Minimum von 35 Bewohnern bzw. Arbeitsplätzen pro Hektar notwendig ist, um einen effizienten und rentablen ÖPNV aufbauen zu können (Newman, P. und J. Kenworthy 2006:47).

Einen vergleichbaren Ansatz verfolgt das NSW Department of Planning, das im Rahmen seiner "City of Cities"-Strategie versucht, 
das Bevölkerungswachstum im Umkreis von regionalen Zentren innerhalb des Stadtgebiets zu konzentrieren. Parramatta soll in diesem Zusammenhang weiter als "Second CBD" gefördert werden. Darüber hinaus ist der Ausbau von Liverpool und Penrith als Zentren der ökonomischen Aktivität mit einer hohen Ausstattung an Arbeitsplätzen und Freizeitmöglichkeiten angedacht. Als Basis des Planungskonzeptes dient die Vorgabe, allen Bürgern der Stadt Pendelzeiten von weniger als einer Stunde pro Tag zu ermöglichen. Vor allem die bisher benachteiligten westlichen Vororte sollen eine bessere ÖPNV Anbindung erhalten. Um die strukturellen Disparitäten zwischen den westlichen und den wassernahen, attraktiveren östlichen Stadtteilen auszugleichen, soll im Westen innerhalb der kommenden 20 Jahre die Hälfte aller neuen Wohnungen und Arbeitsplätze entstehen. Hierbei liegt der Fokus auf der Förderung zweier geplanter Wachstumszentren im Süd- und Nordwesten der Stadt. Diese "Growth Centres" sind unter anderem als Knotenpunkte innerhalb des neuen "North West - CBD - Southwest Rail Link" vorgesehen (vgl. Abschnitt 0) (NSW Department of Planning 2005:23).

\section{Bisherige „Urban Consolidation"-Maßnahmen in Sydney}

Die Auswirkungen des enormen Flächenverbrauchs bei der baulichen Erschließung Sydneys wurden bereits während der 1980er Jahre deutlich. Die permanente Erweiterung der Siedlungsgebiete erforderte hohe Ausgaben zur Bereitstellung der Infrastruktur. Durch die niedrige Bebauungsdichte in den Vororten entstanden große Distanzen zu Arbeitsplätzen und Einkaufszentren, die aufgrund von fehlenden öffentlichen Verkehrsmitteln mit dem privaten PKW zurückgelegt werden mussten. Die Benzinpreisanstiege aus den beiden Ölkrisen der 1970er Jahre, das anhaltende Bevölkerungswachstum und die zunehmende Verschuldung des Bundesstaates New South Wales in den 1980er Jahren zwangen die Stadtplanung schließlich zu einer Erhöhung der Bebauungsdichte auf dem bestehenden Siedlungsgebiet. Die Idee der "dual occupancy", einer nachträglichen Aufteilung der Grundstücke, wurde aufgeworfen, scheiterte aber am starken Widerstand der Gemeinden (Searle 2007:2). Schließlich wurde versucht, innerstädtische 
Baulücken zu schließen und den Anteil der freistehenden Einfamilienhäuser zu verringern. Tabelle 1 illustriert die Entwicklung der freistehenden und nicht freistehenden Häuser im Bereich der "Sydney Statistical Division" von 1981 bis 2006.

\begin{tabular}{|l|c|c|c|c|c|c|c|}
\hline & $\begin{array}{c}\text { freistehende } \\
\text { Häuser }\end{array}$ & $\begin{array}{c}\text { Anstieg } \\
\text { (in \%) }\end{array}$ & $\begin{array}{c}\text { Anteil der } \\
\text { freistehenden } \\
\text { Häuser (in \%) }\end{array}$ & $\begin{array}{c}\text { nicht frei- } \\
\text { stehende } \\
\text { Häuser }\end{array}$ & $\begin{array}{c}\text { Anstieg } \\
\text { (in \%) }\end{array}$ & $\begin{array}{c}\text { Anteil der nicht } \\
\text { freistehenden } \\
\text { Häuser (in \%) }\end{array}$ & Gesamt \\
\hline $\mathbf{1 9 8 1}$ & 765449 & - & 69,0 & 344717 & - & 31,1 & 1110235,0 \\
$\mathbf{1 9 8 6}$ & 822839 & 7,5 & 69,2 & 366846 & 6,4 & 30,8 & 1189761,7 \\
$\mathbf{1 9 9 1}$ & 874040 & 6,2 & 68,0 & 410861 & 12,0 & 32,0 & 1284975,2 \\
$\mathbf{1 9 9 6}$ & 904931 & 3,5 & 66,4 & 458323 & 11,6 & 33,6 & 1363323,9 \\
$\mathbf{2 0 0 1}$ & 907195 & 0,3 & 64,2 & 505838 & 10,4 & 35,8 & 1413097,5 \\
$\mathbf{2 0 0 6}$ & 939074 & 3,5 & 62,2 & 570841 & 12,9 & 37,8 & 1509980,7 \\
\hline
\end{tabular}

Tabelle 1: Entwicklung der Wohnungstypen in der Sydney Statistical Division von 1981-2006 (Quelle: ABS census counts verschiedener Jahrgänge; eigene Berechnungen)

Während Verdichtungsmaßnahmen zu Beginn der "Urban Consolidation" sowohl innerhalb von bereits bebauten Gebieten, als auch am Siedlungsrand durchgeführt wurden, konzentrierten sich die Verdichtungsprojekte Anfang der 1990er Jahre hauptsächlich in industriellen Brachgebieten im Stadtkern wie z.B. in Pyrmont-Ultimo.

Die Strategieentwürfe "Cities for the $21^{\text {st }}$ century" und "Shaping our Cities" von 1995 und 1999 sahen unter dem Leitbild der "Compact City" eine Erhöhung der Siedlungsdichte von durchschnittlich 12 auf 15 Wohneinheiten pro Hektar vor (Schüttemeyer 2005:48). In Pyrmont-Ultimo konnte die Einwohnerzahl durch den Bau von Mehrfamilienwohnungen und mehrgeschossigen Appartements zwischen 1986 und 2000 von 5000 auf ca. 19500 Personen angehoben werden. Aus ökologischer Perspektive kann das "Urban Consolidation"-Projekt in Pyrmont-Ultimo durchaus als Erfolg bewertet werden. Die günstige, city-nahe Lage in Verbindung mit einer guten Anbindung an den ÖPNV und wenigen Parkmöglichkeiten führte zu einer deutlichen Reduzierung des Automobilbedarfs (Braun, Grotz und Schüttemeyer 2005:64).

\section{Kritik an der „Urban Consolidation"}

Gegner der kompakten Stadt erkennen die ökologischen Vorteile einer hohen Siedlungsdichte zwar weitestgehend an, kritisieren aber die sozialen Auswirkungen. Am Beispiel von Pyrmont-Ultimo erweist 
74ISeite Martin Grosch

sich der Anstieg der Immobilienpreise als problematisch, da durch die Verdrängung einkommensschwächerer Familien sozial-räumliche Segmentierungsprozesse entstünden (Waitt 2004:15; Hall 2003:103). Troy (1996:165) erachtet die Ergebnisse von Newman und Kenworthy als zu stark vereinfacht. Die Nutzung des Automobils habe im Zuge von "Gentrification"-Prozessen im Kerngebiet und in den inneren Vororten eher zugenommen, während in den von Einfamilienhäusern dominierten Äußeren Vororten die Wege zum Arbeitsplatz konstant geblieben seien. Kompaktere Stadtstrukturen führten also nicht zur Abnahme der Automobilabhängigkeit, die zunehmende Flächenversiegelung brächte vielmehr einen wachsenden Oberflächenabfluss und somit negative ökologische Konsequenzen mit sich. Einen empirischen Beweis für seine Thesen kann Troy allerdings nicht liefern. Des Weiteren beanstandet Troy (2008:164) die sozialen Auswirkungen innerhalb verdichteter Stadtgebiete. Er weist auf die Entbehrungen für Familien hin, die weder eine große Wohnfläche noch einen Garten zur Verfügung haben. Um Naherholungsmöglichkeiten nutzen zu können, würden die Familien in den verdichteten Wohngebieten vermehrt den privaten PKW gebrauchen. In den Äußeren Vororten könnten sie ihre Freizeit vermehrt im eigenen Garten verbringen.

\section{Auswirkungen der "Urban Consolidation" auf die Bevölkerungsentwicklung in Sydney}

Für die quantitative Analyse wurden die einzelnen "Statistical Local Areas" Sydneys unter dem Kriterium der Entfernung zum Stadtkern in fünf konzentrischen Siedlungsringen (Kerngebiet, innere Vororte, mittlere Vororte, äußere Vororte, Siedlungsrand) zusammengefasst. Ein Vergleich der Entwicklung der Bevölkerungszahlen von 1991 bis 2006 in den genannten Siedlungszonen lässt die Auswirkungen der innenstadtnahen Verdichtungsmaßnahmen erkennen. Im Kerngebiet stieg die Bevölkerung in genanntem Zeitraum um $35 \%$ an (vgl. Abb. 1). Aber auch die Äußeren Vororte und der Siedlungsrand verzeichneten ein hohes prozentuales Wachstum (22 \% bzw. 20\%). 


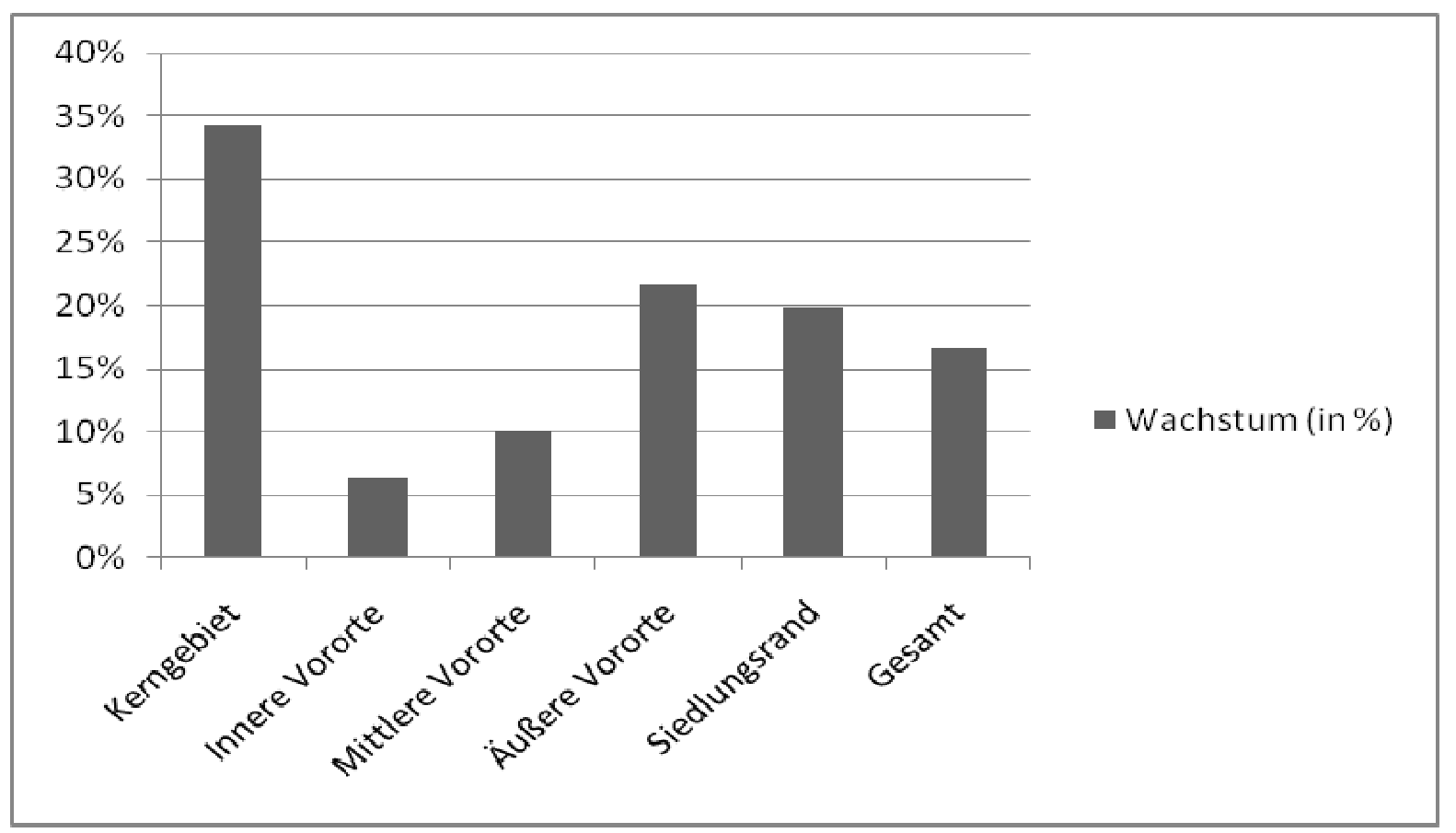

Abbildung 1: Bevölkerungswachstum im Verdichtungsraum Sydney von 1991 bis 2006 -in \%- (Quelle: $A B S$, census counts and estimated resident population der Jahrgänge 1991 und 2006; eigene Berechnungen.)

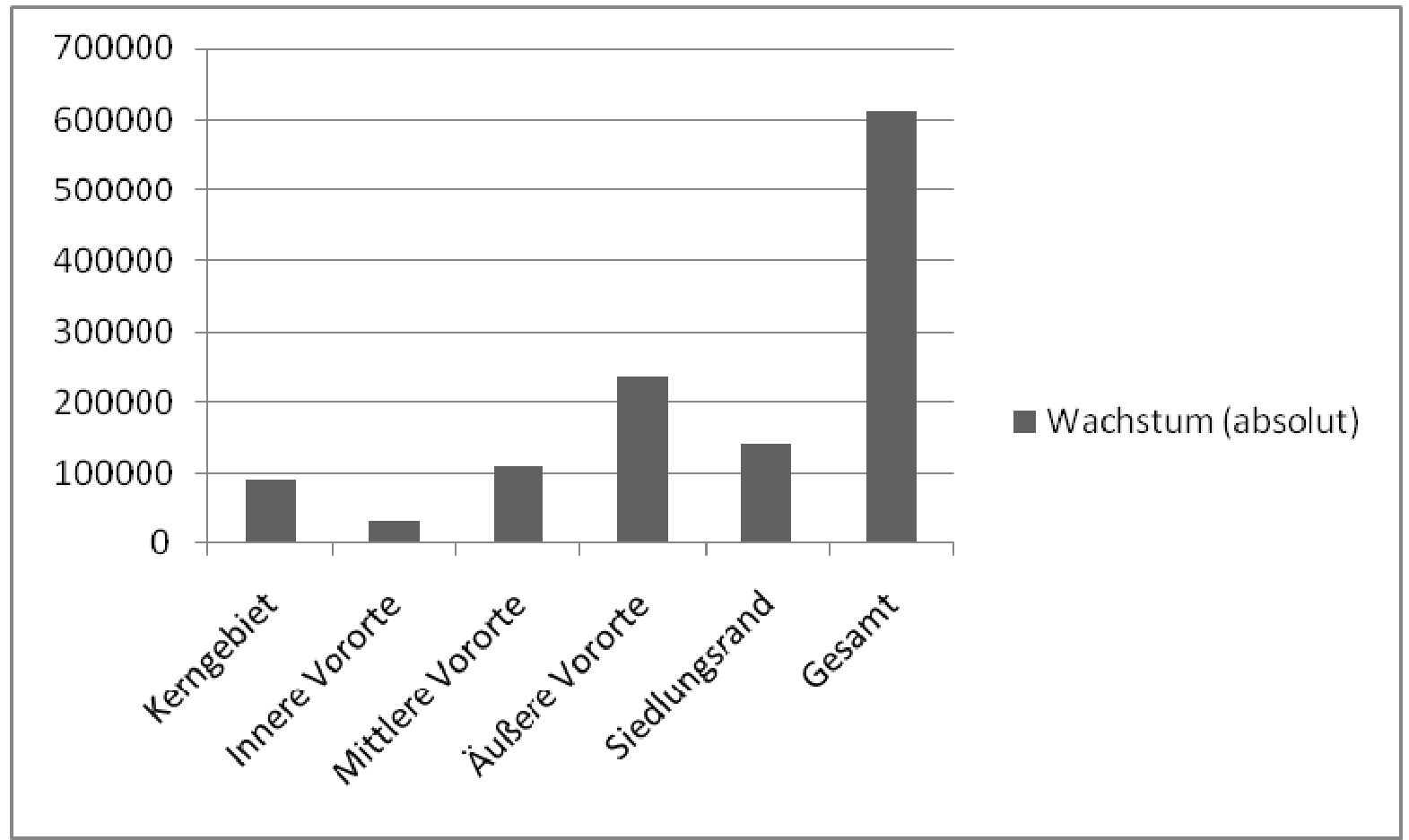

Abbildung 2: absolutes Bevölkerungswachstum im Verdichtungsraum Sydney von 1991 bis 2006 (Quelle: ABS, census counts and estimated resident population der Jahrgänge 1991 und 2006; eigene Berechnungen)

Ein Blick auf die Veränderung der absoluten Bevölkerungszahlen lässt den stärksten Anstieg für die Äußeren Vororte und den Siedlungsrand feststellen (vgl. Abbildung 2). 
Das Vorhaben, die Bevölkerungsdichte im Kerngebiet zu erhöhen, kann also als erfolgreich bewertet werden. Das hohe absolute Bevölkerungswachstum in den äußeren Vororten und am Siedlungsrand weist aber auch auf die Grenzen der "Urban Consolidation" hin: Allein mit Hilfe von innerstädtischen Verdichtungsmaßnahmen wird ein "Doughnut Effect" am Stadtrand nicht abzuwenden sein. Insbesondere das begrenzte Flächenpotenzial im Stadtkern erfordert alternative Konzepte. Der Vorschlag von Newman und Kenworthy (2006:47 f.), in Sydney ein mehrkerniges Stadtmodell zu fördern, scheint hier als geeignet. Aufgrund von Kapazitätsgrenzen in den Innenstädten erachten sie die Etablierung einer polyzentrischen Struktur als unumgänglich. Verdichtete Zentren mit hoher Bevölkerungs- und Arbeitsplatzdichte würden die zurückzulegenden Distanzen für die Bewohner verkürzen und die Verwirklichung eines flächendeckenden und rentablen öffentlichen Verkehrsnetzes ermöglichen. Auf Basis solcher Strukturen könnten dann funktional durchmischte Zentren geschaffen werden, in denen ein ausgewogenes Verhältnis von Wohn-, Arbeits-, Freizeit- und Einkaufsmöglichkeiten vorherrscht. Sofern sich die Arbeitsplätze in fußläufiger Entfernung zu den Wohngebieten befinden, würde sich der Bedarf an der Nutzung motorisierter Verkehrsmittel weiter verringern.

\section{Die Defizite des ÖPNV in Sydney}

\section{"Public transport in crisis"}

Es ist nicht nur die flächenhafte Siedlungsstruktur Sydneys, welche die starke Automobilabhängigkeit bedingt. Verkehrsplanerische Unzulänglichkeiten der vergangenen Jahrzehnte, sowie eine ausgeprägte Ignoranz gegenüber der Endlichkeit der fossilen Energieträger verhinderten nachhaltige Planungskonzepte. Bisherige verkehrsplanerische Maßnahmen standen in erster Linie im Zeichen von Schnelligkeit, Bequemlichkeit und kurzfristiger ökonomischer Rentabilität. Die ökologische Komponente wurde weitestgehend vernachlässigt (Atherton, Riedy \& White 2006:9). Die wachsende öffentliche Wahrnehmung des Klimawandels und die steigenden Ölpreise führten letztlich auch in Sydney zu einer verstärkten Wahrnehmung der Umweltproblematik. Die neue "Transport Strategy" des NSW Department of Planning, die den planerischen 
Schwerpunkt auf eine umweltverträgliche Entwicklung im Stadtverkehr setzt, ist Ausdruck für dieses Umdenken. Nichtsdestotrotz weist das aktuelle Sydneyer Verkehrssystem Defizite auf, was sich durch vielerorts fehlende Zugangsmöglichkeiten zum ÖPNV und zu geringe Investitionen in das Schienennetz widerspiegelt. Darüber hinaus stehen reduzierte Frequenzen im Schienen- und Busverkehr, uneinheitliche TicketSysteme und im Vergleich zur Nutzung des PKW teure Preise im ÖPNV sinnbildlich für das schlechte Image des öffentlichen Verkehrs.

Mit Hilfe eines integrierten, bargeldlosen Ticket-Systems für Sydneys Busse, Züge und Fähren sollte im Jahr 2008 eine signifikante Verbesserung des veralteten Systems herbeigeführt werden. Das 95 Mio. AUD teure Kooperationsprojekt mit der Firma ERG aus Perth sah die Entwicklung einer "Smart Transport Card" vor. Am 24. Januar 2008 berichtete der Sydney Morning Herald jedoch vom Scheitern des Vorhabens. Aufgrund von permanenten Verzögerungen von Seiten der Firma ERG wurde die Zusammenarbeit von der Stadtverwaltung gekündigt. Die Realisierung des integrierten Ticketsystems sei in Folge dessen innerhalb der kommenden zehn Jahre nicht mehr zu erwarten (Sydney Morning Herald vom 24. Januar 2008:6).

Ein weiteres Problem stellt die Überlastung der öffentlichen Verkehrsmittel dar. Durch die geplante Ansiedlung von 650000 neuen Bewohnern werden die Kapazitätsgrenzen des ÖPNV weit überschritten (Searle 2006:560). Viele Pendler bevorzugten in dieser Situation aus Bequemlichkeits- und Schnelligkeitsgründen den privaten PKW für die Fahrt zum Arbeitsplatz. Wie Glazebrook (2006:21) feststellt, übersteigt der Pro-KopfPrimärenergieverbrauch von Autos in Sydney den von Bussen und Zügen jedoch um das Dreifache. Im Jahr 1999 betrug der Jahreswert an automobilbedingten Pro-Kopf- $\mathrm{CO}_{2}$-Emissionen in Sydney $2446 \mathrm{~kg}$. Aus der ÖPNV-Nutzung resultierten hingegen nur $142 \mathrm{~kg} \mathrm{CO} 2$ pro Kopf (Newman, Kenworthy \& Laube 1999:603). Eine Verbesserung der öffentlichen Verkehrs-infrastruktur würde somit ökologische Entlastungen bewirken. 


\section{Projekte zum Ausbau des öffentlichen Verkehrsnetzes in Sydney}

Die Metropolitan Strategy "City of Cities. A plan for Sydney's growth" sieht den Ausbau und die Vernetzung von einzelnen regionalen Zentren innerhalb des Stadtgebietes vor. Der Bau einer Schienenverbindung vom nordwestlichen Wachstumszentrum über den CBD zum südwestlichen Wachstumszentrum soll eine effiziente Vernetzung der großen Wohn- und Arbeitsplatzzentren garantieren. Ziel dieses "North West - CBD - South West Rail Link" ist eine ununterbrochene Verbindung zwischen Rouse Hill und Castle Hill im Nordwesten, den Arbeitsplatzzentren Macquarie, Chatswood, North Sydney und Sydney CBD mit Leppington und Campbelltown/ Macarthur im Südwesten. Informationen des Sydney Morning Herald zufolge ist das Vorhaben des "North West Rail Links", also der Teilstrecke vom CBD in den Nordwesten, aber noch keineswegs garantiert. Neue Überlegungen der Stadtplanung ziehen den Bau einer 12 Milliarden AUD teuren U-Bahnlinie vom Stadtzentrum über West Ryde bis in den Hills District in Erwägung. Im Falle einer Realisierung wäre der ursprünglich in der "Transport Strategy for Sydney" veröffentlichte Plan einer überirdischen Schienenverbindung ad acta gelegt. Das U-Bahn-Projekt würde mehrere Jahre an Planung in Anspruch nehmen, bis mit der eigentlichen Bautätigkeit begonnen werden könnte. Die Wartezeit vieler Bürger auf die Möglichkeit, ein öffentliches Verkehrsmittel nutzen zu können, würde sich damit weiter verlängern (Sydney Morning Herald vom 26. Februar 2008:4).

Für die Raum- und Verkehrsplanung ergäben sich in Zusammenhang mit dem beschriebenen Großprojekt in jedem Fall neue Handlungsspielräume. Verdichtungsmaßnahmen würden nunmehr nicht nur in den Stadtzentren sinnvoll, sondern auch entlang der Bahnlinien und insbesondere im Einzugs-bereich der neu entstehenden Bahnhöfe. Inwieweit dies an den verschiedenen Standorten realisierbar ist, müsste anhand von kleinräumlichen Untersuchungen überprüft werden.

\section{Räumliche Analyse der automobilbedingten Umwelt- belastung in Sydney}

Die aus der Mobilität resultierenden Treibhausemissionen tragen in den australischen Metropolen einen erheblichen Teil zur Belastung der Atmosphäre bei. In Sydney sind die verkehrsbedingten $\mathrm{CO}_{2}$ Emissionen zwischen 1990 und 2005 um 31 \% angestiegen. Der 
Anteil der privaten PKW an den im Jahr 2005 ausgestoßenen 559,1 Millionen Tonnen $\mathrm{CO}_{2}$ betrug $61,8 \%$ (Australian Greenhouse Office 2007:11 ff.). Bleiben adäquate raum- und verkehrsplanerische Maßnahmen aus, wird mit dem Bevölkerungswachstum eine steigende Umweltbelastung einhergehen. Sicherlich werden Fortschritte in der Fahrzeugtechnologie Einsparungen bewirken können, die Abnahme der Gesamtemissionen ist dadurch aber nicht zu erwarten. Sich allein auf die Annahmen von technologischen Verbesserungen zu beschränken wäre also sicher unzureichend. Vielmehr ist es notwendig, die Ansiedlung der neuen Bevölkerung in Sydney mit einer umweltverträglichen Mobilität zu vereinbaren. Ziel der im Folgenden beschriebenen Analyse ist es, die räumliche Verteilung der automobilbedingten Pro-Kopf- $\mathrm{CO}_{2}$-Emissionen innerhalb der einzelnen Stadtregionen Sydneys darzustellen. Indem die Emissionswerte mit weiteren ökonomischen, räumlichen und sozio-demographischen Daten in Beziehung gesetzt werden, wird herausgearbeitet, welche Indikatoren ausschlaggebend für eine starke bzw. schwache Automobilabhängigkeit sind. Zudem soll mit Hilfe der quantitativen Analyse die Frage beantwortet werden, in welchen Stadtgebieten aktuell ein günstiges Potenzial zur Ansiedlung der wachsenden Bevölkerung besteht.

Anhand zweier Grafiken und einer thematischen Karte werden zunächst die räumlichen Unterschiede der automobilbedingten $\mathrm{CO}_{2}$ Emissionen in Sydney visualisiert:

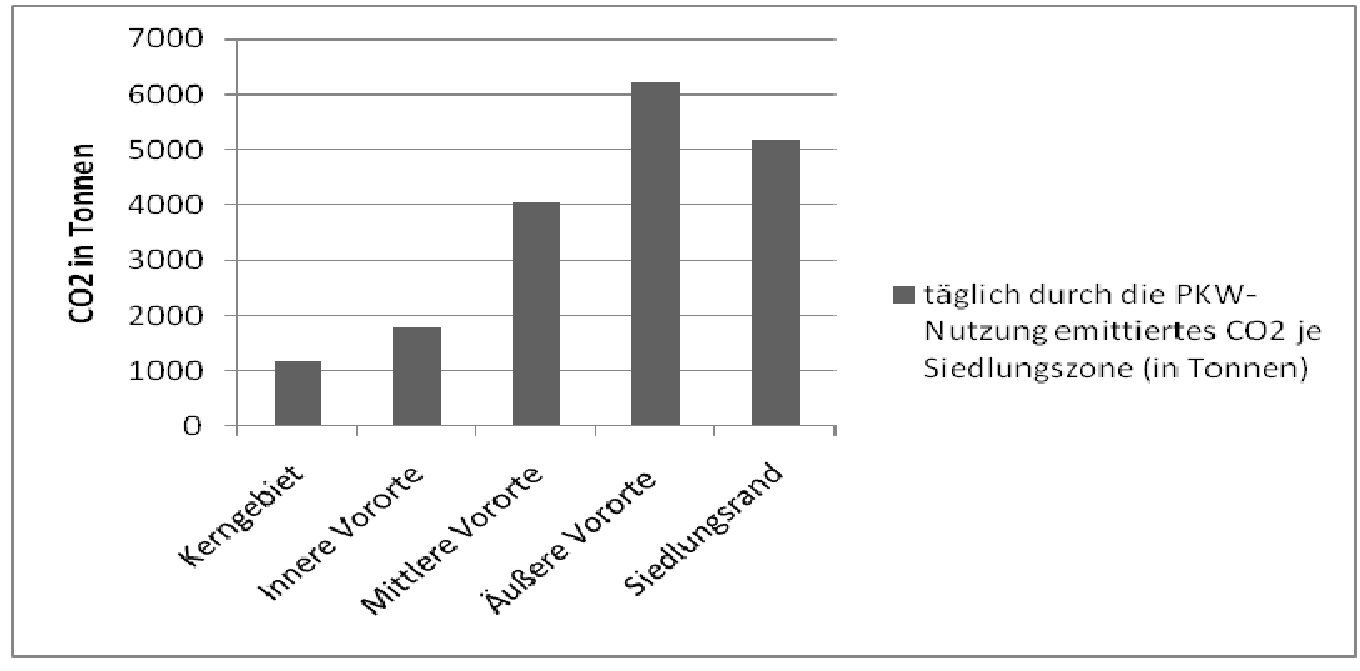

Abbildung 3: Darstellung der täglich aus der PKW-Nutzung entstehenden $\mathrm{CO}_{2}$-Emissionen in Sydney je Siedlungszone (Quelle: HTS (2004), ABS Census Quickstats je SLA (2006) und Angaben der Federal Chamber of Automotive Industries (2008) zu den durchschnittlichen $\mathrm{CO}_{2}$-Emissionen 
80ISeite Martin Grosch

Abb. 3 stellt die täglichen aus der Automobilnutzung entstehenden $\mathrm{CO}_{2}$-Emissionen je Siedlungszone dar. Die Werte steigen vom Kerngebiet zu den Äußeren Vororten und nehmen dann wieder leicht ab. Wie erwartet ist die Gesamtbelastung in den weiter vom Stadtkern entfernten Vororten am höchsten. Rechnet man die dargestellten absoluten Werte in Pro-Kopf-Werte um, ergibt sich folgendes Ergebnis:

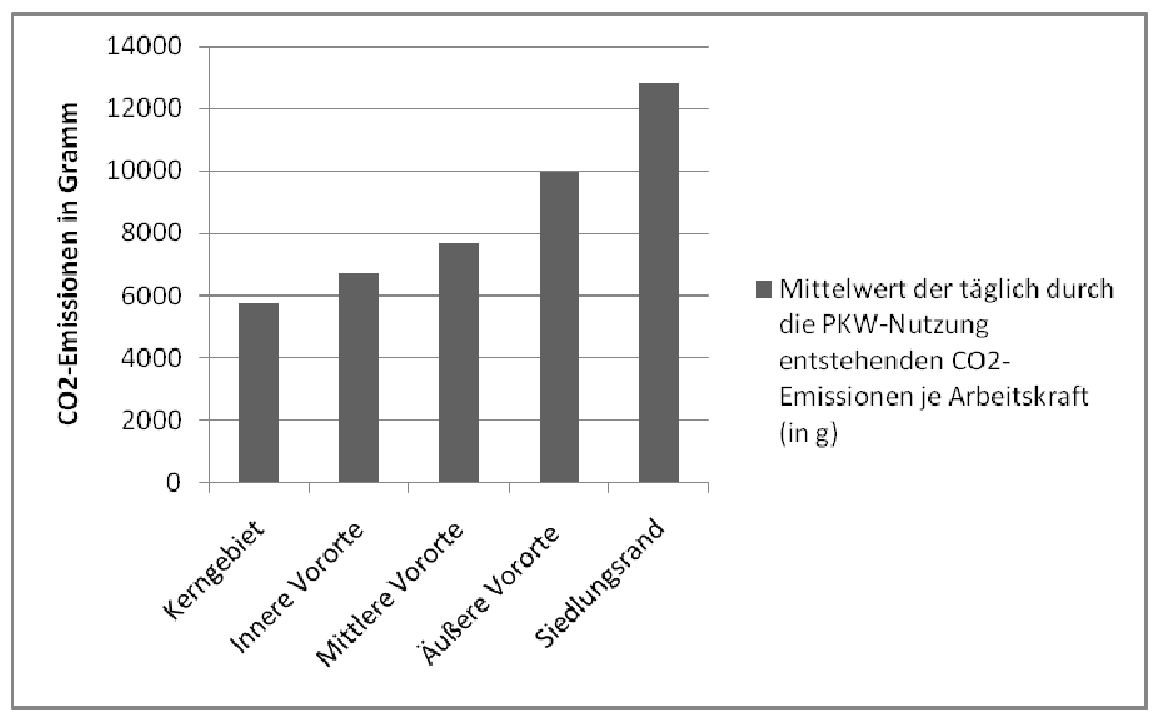

Abbildung 4: Mittelwert der täglich aus der PKW-Nutzung entstehenden $\mathrm{CO}_{2}$-Emissionen je Arbeitskraft (Quelle: HTS (2004), ABS Census Quickstats je SLA (2006) und Angaben der Federal Chamber of Automotive Industries (2008) zu den durchschnittlichen $\mathrm{CO}_{2}$-Emissionen der Autos mit einem Leergewicht von weniger als 3,5 Tonnen; eigene Berechnungen)

Abbildung 4 und Karte 1 bestätigen die Annahme der steigenden automobilbedingten Pro-Kopf- $\mathrm{CO}_{2}$-Emissionen mit wachsender Distanz vom Stadtkern. Es stellt sich nun die Frage nach den Gründen für das festgestellte Muster.

Unter Bezugnahme auf die Ergebnisse bisheriger Arbeiten soll im Folgenden zunächst thesenhaft eine Reihe möglicher Faktoren aufgelistet werden. Eine multilineare Regressionsanalyse wird im zweiten Schritt herausstellen, welche dieser Faktoren den größten Einfluss auf die täglich aus der PKW-Nutzung resultierenden ProKopf- $\mathrm{CO}_{2}$-Emissionen haben.

Zunächst wird ein Zusammenhang zwischen PKW-Verfügbarkeit und Mobilitätsverhalten angenommen. Durch die verhältnismäßig hohe Bebauungsdichte im Kerngebiet und in den inneren Vororten sind 
die Parkmöglichkeiten stärker eingeschränkt. Für die Bewohner wird die Anschaffung eines Zweitwagens dadurch unattraktiver. Unter Umständen spielen in diesem Zusammenhang auch die Einkommensverhältnisse eine Rolle.

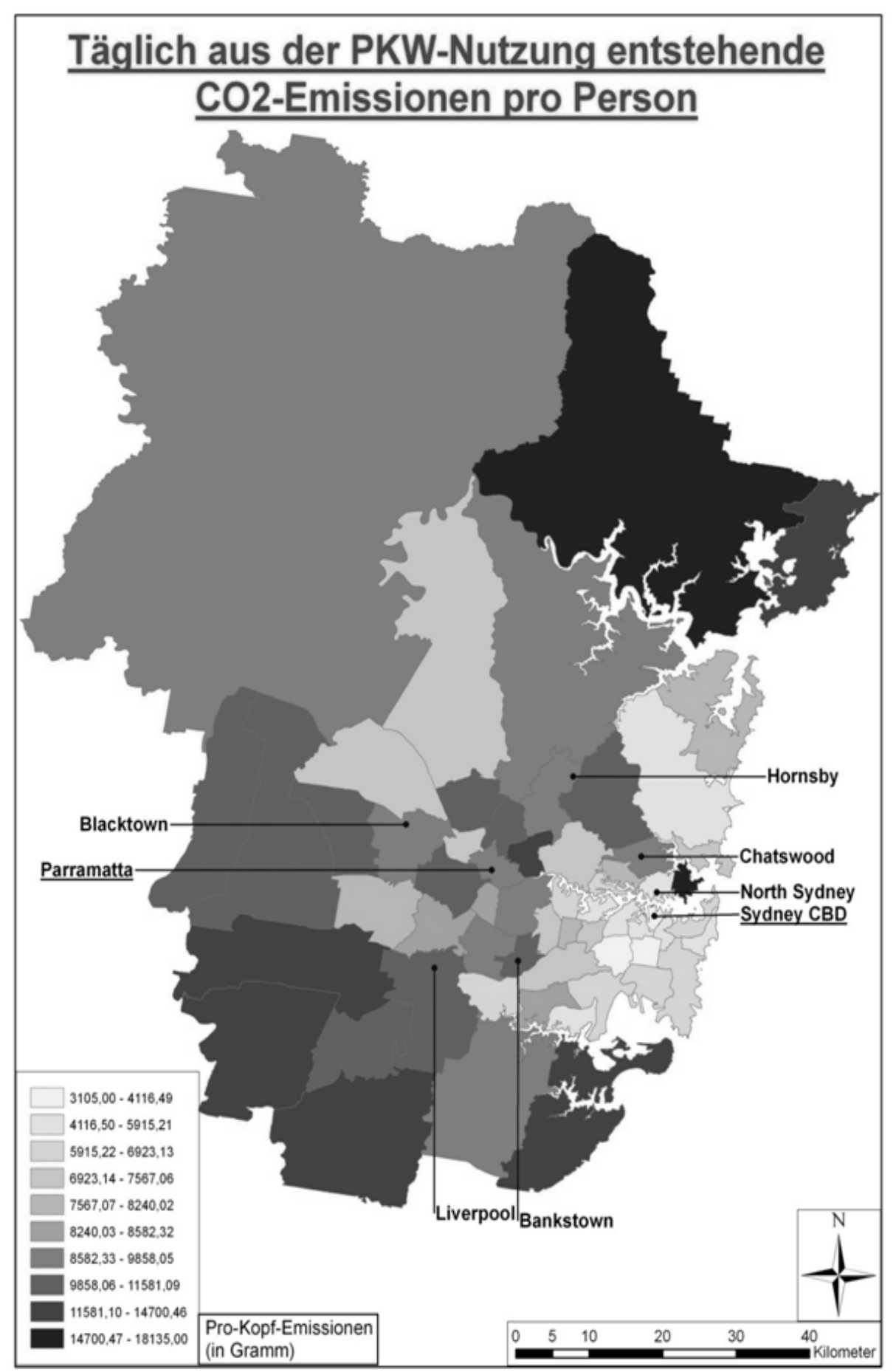

Karte 1: Täglich aus der PKW-Nutzung entstehende CO2-Emissionen in Sydney pro Person (Quelle: HTS (2004), ABS Census Quickstats je SLA (2006) und Angaben der Federal Chamber of Automotive Industries (2008) zu den durchschnittlichen C02Emissionen der Autos mit

Besserverdienende Haushalte können sich einfacher einen Zweitwagen leisten als einkommensschwächere, die folglich stärker 
auf die Nutzung öffentlicher Verkehrsmittel angewiesen sind. Es wird also vorab von einem Zusammenhang zwischen Einkommen, PKWVerfügbarkeit und Automobilnutzung ausgegangen.

Zweitens dürfte die Bebauungsdichte sowohl die Zahl als auch die Länge der täglichen Fahrten mit dem PKW beeinflussen. Hinzu kommt die Schwierigkeit, in Gebieten mit niedriger Bevölkerungsdichte ein rentables ÖPNV-System zu etablieren. Je weniger Menschen im Umkreis einer Haltestelle wohnen, umso geringer ist deren Frequentierung. Eine niedrige Bebauungsdichte erhöht also nicht nur die durchschnittlichen Distanzen zu Arbeitsplätzen und Erholungsgebieten, sondern auch zu den ÖPNV-Haltestellen.

Drittens werden in stark funktional durchmischten Gebieten verhältnismäßig niedrige automobilbedingte $\mathrm{CO}_{2}$-Emissionen $\mathrm{zu}$ erwarten sein. Reine Wohngebiete verfügen über ein niedriges Maß an Funktionsmischung. Die geringe Arbeitsplatzverfüg-barkeit in den monostrukturierten Wohnsiedlungen zwingt die erwerbstätigen Bewohner, relativ weite Strecken zu ihrem Arbeitsplatz zurückzulegen. Fehlt es an einer konkurrenzfähigen ÖPNVAnbindung, so sind sie auf die Nutzung des privaten PKW angewiesen. Auf der anderen Seite ergeben sich in funktional durchmischten Gebieten mit einem guten Angebot an Arbeitsplätzen kurze Wege für die Erwerbstätigen, die mit nicht-motorisierten Verkehrsmitteln oder zu Fuß zurückgelegt werden können. Die Abhängigkeit vom Automobil reduziert sich also, je höher sich die lokale Verfügbarkeit an Arbeitsplätzen darstellt. In Sydney befindet sich der Großteil der Arbeitsplätze im CBD. Die jeweilige Distanz von den Vororten zum CBD dürfte demnach ebenfalls ein Kriterium darstellen. Somit stehen zur Erarbeitung der Einflussfaktoren auf die räumliche Verteilung der automobilbedingten Pro-Kopf- $\mathrm{CO}_{2}-$ Emissionen folgende Variablen zur Verfügung: 
- Straßendistanz zum CBD $\left(\mathrm{x}_{1}\right)$

- Anteil der Fahrten mit dem PKW am Modal Split ( $\left.x_{2}\right)$

- Bebauungsdichte (in Wohneinheiten pro Hektar) $\left(x_{3}\right)$

- Zugang zum ÖPNV $\left(\mathrm{X}_{4}\right)$

- durchschnittliche PKW-Verfügbarkeit je Haushalt $\left(x_{5}\right)$

- durchschnittliches wöchentliches Haushaltseinkommen $\left(x_{6}\right)$

- Arbeitsplätze pro Erwerbstätigem je SLA $\left(x_{7}\right)$

\section{Statistische Analyse}

Um den Grad des Einflusses der einzelnen Variablen auf die automobilbedingten $\mathrm{CO}_{2}$-Emissionen berechnen $\mathrm{zu}$ können, bietet sich eine statistische Analyse in Form einer multilinearen Regressionsrechnung an. Während bei einer einfachen Korrelationsanalyse bzw. einer einfachen linearen Regressionsanalyse lediglich geprüft wird, ob der Zusammenhang zweier Variablen signifikant ist, prüft die multivariate Regressionsanalyse mehrere unabhängige Variablen auf einen signifikanten Zusammenhang mit einer abhängigen Variablen. In diesem Fall sind dies die aus der täglichen PKW-Nutzung resultierenden $\mathrm{CO}_{2}$ Emissionen je Arbeitskraft (y).

In Abschnitt 4 wurde bereits ein kausaler Zusammenhang zwischen den einzelnen unabhängigen Variablen und der abhängigen Variable vermutet. Diesen gilt es nun mit Hilfe der statistischen Analyse zu testen. Betrachtet man das Verhältnis der unabhängigen Variablen untereinander, so müssen auch hier kausale Zusammenhänge erwartet werden. Für die Regressionsrechnung bedeutet eine solche Interkorrelation von unabhängigen Variablen aber eine Verfälschung des Ergebnisses (Multikollinearität). Es ist also zunächst notwendig für die unabhängigen Variablen eine Kollinearitätsdiagnose durchzuführen. Für die verbleibenden Werte wird ein kritisches Signifikanzniveau $\left(W_{\text {krit }}>0,05\right)$ festgelegt. Überschreiten die Signifikanzniveaus einzelner, unabhängiger Variablen den kritischen Wert, besteht kein signifikanter Zusammenhang zwischen abhängiger und unabhängiger Variable. Nachdem die beschriebenen Ausschlussverfahren in mehreren Schritten durchgeführt und alle Störvariablen entfernt wurden, verbleiben drei unabhängige Variablen: 
84ISeite Martin Grosch

- Bebauungsdichte (in Wohneinheiten pro Hektar) $\left(x_{3}\right)$

- Zugang zum ÖPNV $\left(\mathrm{x}_{4}\right)$

- durchschnittliche PKW-Verfügbarkeit je Haushalt $\left(x_{5}\right)$

\begin{tabular}{|c|c|c|c|c|}
\hline \multicolumn{5}{|c|}{ Modellzusammenfassung } \\
\hline Modell & $\mathrm{R}$ & R-Quadrat & $\begin{array}{c}\text { Korrigiertes R- } \\
\text { Quadrat }\end{array}$ & $\begin{array}{c}\text { Standardfehler des } \\
\text { Schätzers }\end{array}$ \\
\hline 1 &, $847^{\mathrm{a}}$ &, 718 &, 697 & 1800,59144 \\
\hline $\begin{array}{l}\text { a. Einflussvariablen : (Konstante), Zugang zum ÖPNV, Bebauungsdichte, durchschnittliche } \\
\text { Anzahl an PKWs pro Haushalt }\end{array}$ \\
\hline
\end{tabular}

Tabelle 2: Zusammenfassung des Regressionsmodells

Es ergibt sich folgende Regressionsgleichung:

$$
y=3098,972+\left(-34,595 \cdot x_{3}\right)+91,356 \cdot x_{4}+3262,706 \cdot x_{5}
$$

Die Regressionsrechnung bestätigt zunächst die Annahmen von Newman \& Kenworthy (1999) und Schüttemeyer (2005). Bezüglich der Arbeitsplätze je Erwerbstätigem $\left(x_{7}\right)$ konnte hingegen kein Zusammenhang festgestellt werden. Die Zugangsmöglichkeiten zum ÖPNV sowie die PKW-Verfügbarkeit spielen hinsichtlich der räumlichen Verteilung der automobilbedingten Pro-Kopf- $\mathrm{CO}_{2}-$ Emissionen ebenfalls eine Rolle. Auch Corpuz, McCabe und Ryszawa (2003:3) kommen bei einer Untersuchung zur Mobilität in Sydney zu dieser Erkenntnis.

Es soll an dieser Stelle noch einmal darauf hingewiesen werden, dass mit Hilfe des Regressionsmodells zwar eine signifikante Korrelation der Variablen $\mathrm{x}_{3}, \mathrm{x}_{4}$ und $\mathrm{x}_{5}$ errechnet werden konnte, das abschließende Modell besteht aber den Multikollinearitäts-Test nicht. Eine Problematik, die sich auch bei weiteren Veränderungen des Modells nicht beheben lässt. Es liegt demnach kein eindimensionales Beziehungsgeflecht vor, bei dem die einzelnen unabhängigen Variablen ausschließlich Einfluss auf die Zielvariable nehmen. Vielmehr muss von einem zirkulären Zusammenhang ausgegangen werden.

Bei der Interpretation der mathematischen Resultate ist eine starke Korrelation der PKW-Verfügbarkeit je Haushalt mit den Pro-Kopf$\mathrm{CO}_{2}$-Emissionen festzustellen. Diesbezüglich sind Planung und Politik 
in Australien sowohl auf nationaler als auch auf föderaler Ebene gefragt, für Haushalte die Anschaffung von Zweit- oder Drittwagen unattraktiv zu gestalten. Es bietet sich an, die direkten und indirekten Kosten für den Kauf eines privaten PKW zu erhöhen. Die Einführung einer Öko-Steuer, die eine Verteuerung des im internationalen Vergleich günstigen australischen Benzins bewirken würde, könnte die Bürger zu einer verstärkten Nutzung öffentlicher oder nicht-motorisierter Verkehrsmittel bewegen. Sicher würde die steuerliche Mehrbelastung der Bürger auf erhebliche Widerstände von Seiten der Öffentlichkeit und der Wirtschaft stoßen.

Gegenargumente können vor allem aus sozialer Perspektive erhoben werden, da besonders Einkommensschwächere stärker belastet würden. Reinvestiert man aber die steuerlichen Mehreinnahmen in den Ausbau des öffentlichen Verkehrsnetzes und garantiert dadurch jedem Bürger die Erreichbarkeit der städtischen Zentren, so wäre die Maßnahme auch sozial vertretbar. Würde die Nutzung des privaten PKW verteuert, müsste also gleichzeitig jedem Bürger der Zugang zum öffentlichen Verkehrsnetz gewährleistet sein. Die ÖPNV-Nutzung müsste zudem aus finanziellen Aspekten und in punkto Schnelligkeit gegenüber der Nutzung des Automobils konkurrenzfähig gestaltet werden. In dieser Hinsicht bietet sich neben dem Ausbau des Schienennetzes auch die flächendeckende Einführung von Buslinien an, was den Bussen in Sydney gegenüber den PKW Schnelligkeitsvorteile verschaffen würde.

Die Regressionsrechnung bestätigt den erwarteten Zusammenhang von steigenden automobilbedingten $\mathrm{CO}_{2}$-Ausstößen mit sinkender Bebauungsdichte. Um die oben beschriebenen Verbesserungen des ÖPNV realisieren zu können, ist die Schaffung von städtebaulichen Rahmenbedingungen unumgänglich. Besonders in den bestehenden städtischen Zentren, aber auch in den neu geplanten Gebieten müssen daher kompakte Strukturen und eine ausgewogene Funktionsmischung die Grundlage für weitere Verbesserungsansätze bilden.

Die Maßnahmen und Strategien zur Reduzierung der automobilbedingten Umweltbelastung, die in Bezug auf die beschriebenen 
86 ISeite Martin Grosch

Ergebnisse ergriffen werden könnten, sollen abschließend noch einmal zusammengefasst und diskutiert werden.

\section{Strategien für eine umweltverträgliche Mobilität in Sydney}

Das für die kommenden Jahre erwartete Bevölkerungswachstum in Sydney bedeutet eine große Herausforderung, bietet aber auch eine große Chance für die Raumplanung, die Stadtstruktur und in diesem Zusammenhang die Mobilität ökologisch nachhaltig zu gestalten. Der Übergang von einer flächenhaften zu einer kompakten Stadt muss hierbei die Planungsgrundlage bilden. Die aktuelle "Metropolitan Strategy" des NSW Ministry of Planning setzt den planerischen Schwerpunkt auf die Förderung eines polyzentrischen Stadtmusters, bei dem die bestehenden Arbeitsplatzzentren und die beiden neuen Wachstumszentren im Nord- und Südwesten als Stadtkerne dienen. Dort soll insbesondere ein gutes Maß an funktionaler Durchmischung gewährleistet werden. Neben einer hohen Arbeitsplatzdichte sind weitere Wohn-, Freizeit und Einkaufszentren geplant. Vor allem die angedachten Verdichtungsmaßnahmen in den Zentren und in den Subzentren dürften, im Falle einer konsequenten Durchführung, eine Verkürzung der zu überbrückenden Distanzen und somit eine deutliche Verbesserung der aktuellen Strukturen bewirken.

Nichtsdestotrotz unterstreicht die statistische Untersuchung die Notwendigkeit von flächendeckenden Investitionen in die öffentliche Verkehrsinfrastruktur. Sowohl der Zustand in vielen peripheren, nahezu vollständig vom öffentlichen Verkehrsnetz isolierten Vororten, als auch die Kapazität des bestehenden ÖPNV müssen deutlich verbessert werden. Für die Ansiedlung der neuen Bevölkerung könnten neben den Wachstumszentren Verdichtungsmaßnahmen in denjenigen Stadtgebieten in Erwägung gezogen werden, die bereits aktuell über eine gute Anbindung an den ÖPNV verfügen. Einzelne Vororte des Kerngebiets, der inneren und mittleren Vororte bieten sich hier an. Sicher ist dort die Flächenverfügbarkeit durch die bereits relativ dichte Bebauung begrenzt, dennoch könnten Industriebrachen oder Altbauten lokalisiert und baulich erneuert werden. Geringe Kosten für die Erschließung der Infrastruktur stellen für solche Maßnahmen einen weiteren Vorteil dar. 
Die aus der "Urban Consolidation" zu erwartenden sozialen Segregationsprozesse sind nicht von der Hand zu weisen. Um die Verdrängung einkommensschwächerer Familien aus den attraktiven, zentrennahen Wohnvierteln zu verhindern, bieten sich soziale Wohnungsbauprojekte an, die auch im Rahmen der staatlichen "Affordable housing policy" geplant sind. Vor allem den Arbeitnehmern des öffentlichen Sektors ("Key Workers") soll damit ein arbeitsplatznahes Wohnen ermöglicht werden.

Zusammenfassend bietet sich also für die Planung von neuen verdichteten Siedlungen an, ein ausgewogenes Verhältnis von Wohn-, Arbeits-, Einkaufs- und Freizeitmöglichkeiten zu garantieren, ÖPNV-Haltestellen für alle Bewohner in fußläufiger Distanz zu lokalisieren und das Angebot an Parkplätzen möglichst gering zu halten. Sofern es gelingt, die genannten Strukturen in den Stadtzentren und deren Einzugsgebieten zu etablieren, kann von einer deutlichen Reduzierung der automobilbedingten Umweltbelastung ausgegangen werden.

Neben der Verwirklichung von günstigen räumlichen Strukturen, besteht auch ein politischer Spielraum, die Nutzung des Automobils einzuschränken. Zunächst könnte das Bewusstsein gegenüber dem Klimawandel und dessen negativen Auswirkungen mit Hilfe von öffentlichen Aufklärungs- bzw. Marketingkampagnen geschärft werden. Noch wichtiger erscheint aber eine politische Steuerung der Benzinpreise. Durch die Einführung einer landesweiten Benzin- oder Mineralölsteuer könnte der Preis des im internationalen Vergleich günstigen australischen Benzins an ein europäisches Niveau angeglichen werden. Sowohl aus ökologischer als auch aus sozialer Perspektive wäre dies wünschenswert.

Alles in Allem macht die abschließende Betrachtung des Sachverhaltes Eines deutlich: Die Möglichkeiten für die Schaffung einer umweltverträglichen Stadtstruktur sind in Sydney gegeben. Inwieweit diese in die Tat umgesetzt werden, hängt in erster Linie von der Bereitschaft der Politiker und Planer ab, aus Sydney eine "Green City" zu machen. Dies würde letztlich einen Beitrag zur Einhaltung der Kyoto-Ziele und möglichen Nachfolgeabkommen zum Klimaschutz leisten. 


\section{Literaturverzeichnis}

Australian Bureau of Statistics, 2006. Sydney ... A Social Atlas. Canberra.

Atherton, A., Riedy, C. und S. White, 2006. Moving on: the RTBU's public transport blueprint for Sydney. Institute for sustainable futures. University of Technology, Sydney.

Besser, L. und A. Smith, 2008. "City catches \$12b metro." In: Sydney Morning Herald vom 19. März 2008, S. 1 und 4.

Braun, B., Grotz, R. und A. Schüttemeyer, 2001. "Von der flächenhaften zur verdichteten Stadt: Ansätze der nachhaltigen Stadtentwicklung in Sydney." Petermanns Geographische Mitteilungen, 145 (5), 56-65.

Breheny, M. 2008. "Centrists, decentrists and compromisers: views on the future of urban form." In: Jenks, M., Burton, E. und K. Williams, Hrsg. ${ }^{2}$, The Compact City: a sustainable urban form? London: Spon Press, 1335.

Corpuz, G., McCabe, M. und K. Ryszawa, 2006. The Development of a Sydney VKT Regression Model. Gold Coast, $29^{\text {th }}$ Australasian Transport Research Forum.

Federal Chamber of Automotive Industries, 2008. National average carbon emissions. Canberra.

Forster, C., 20043. Australian cities. Continuity and change. Melbourne: Oxfor University Press

Glazebrook, G., 2006. Taking the con out of convenience: the true costs of transport modes in Sydney. Faculty of Design, Architecture and the Built Environment. University of Technology, Sydney.

Hall, T., 2003. "Car-ceral cities. Social Geographies of everyday urban mobility." In: Miles, M. und T. Hall, Hrsg., Urban futures. Critical commentaries on shaping the city, New York: Routledge, 92-105.

Newman, P. und J. Kenworthy, 1999. Sustainability and Cities. Overcoming Automobile Dependence. Washington D. C.: Island Press.

Newman, P. und J. Kenworthy, 2006. "Urban Design to reduce automobile dependence." In: Opolis (2 (1)), 35-52.

Newman, P., Kenworthy, J. und F. Laube, 1999. "The Global City and Sustainability-Perspectives from Australian Cities and a Survey of 37 Global Cities." In: Brotchie, J.,Newton, P. und J. Dickey, Hrsg., East West Perspectives on 21stCentury Urban Development, Aldershot, 327354

NSW Department of Planning, 2005. NSW Government's Metropolitan Strategy: City of Cities. A plan for Sydney's future. Sydney.

Searle, G., 2006. "Is the City of Cities Metropolitan Strategy the answer for Sydney?" In: Urban Policy and Research, 24 (4), 553-566.

Searle, G., 2007. "Sydney's urban consolidation experience: power, politics and community" In: Urban Research Program. Research Paper 12. Brisbane. 
Schüttemeyer, A. 2005. "Verdichtete Siedlungsstrukturen in Sydney. Lösungsansätze für eine nachhaltige Stadtentwicklung." In: Bonner Geographische Abhandlungen, Heft 113, Bonn, Ferger Verlag.

Smith A., 2008. "Sydney's $\$ 260 m$ cheap home plan." In: Sydney Morning Herald vom 29. April 2008, S. 6.

Smith A., 2008. " $\$ 95 \mathrm{~m}$ down the drain, and transport card is years off" In: Sydney Morning Herald vom 24. Januar 2008, S. 1 und 6.

Troy, P. N., 1996. The perils of urban consolidation. Leichhardt: The Federation Press.

Troy, P. N., 2008, "Urban consolidation and the family." In: Jenks, M., Burton, E. und K. Williams Hrsg. The Compact City. A sustainable urban form?, London: Spon Press, 45-52

Waitt, G., 2004. "Pyrmont-Ultimo: the Newest Chic Quarter of Sydney." In: Bell, D. und M. Jayne, Hrsg., City of Quarters. Urban Villages in the Contemporary City, Aldershot, 15-36. 
Robyn Rowland

The night you came

I've seen it before: Mannin coral strand

shining ivory cream in late day, amber wrack on the pitch-black rock whiskering around the bay;

Bens caked in snow their quartzite veins pumping water under a tarred and boiling sky; that curragh in Seal Bay, strangely painted bright wode-blue, listing under a gale before it's hauled up to dry shelter.

Air so translucent on a still day there was no need for breath suspended as we were in the very heart of it in the plenty of it in the exhausted contentment of it after tramping between spooks along the bog road, light a medium of clear mist, angels' breath sky to loch to land, as we sat.

Or summer's glaze at Grace's kitchen window so bright it burns away all thoughts of any other place; sea beyond, blue as a feather off the peacock on Pat's cold chimney top. For some reason unknowable to us all, it cries and gazes towards the sea from the half-stoned house below. We never know what that means: a peacock on the roof in the wild west of Ireland.

But the night you came, when I hoped but did not know why, or for what; the night you went, 
when I did not weep but fell quiet;

the moon was all gold

like never before,

big as old currency, doubloon fat, pirate rich.

A Midas moon, dripping with Minoan gold.

Maybe it had slipped

inside the sun's skin

dropped as it disrobed for sleep.

Maybe it was real as a necklace

from Crete's hoarded past.

Maybe it was only plate, fit to peel and flake,

enlarged reflection of a small candle flame

distorted through old pane glass; a bulging fake;

or a daisy-daft trick-of-the-eye.

But I never, never saw it like that.

\section{What we made}

Look at you, wood-dreaming,

palms smooth around the rosewood lamp you turned

deep in your cave beneath the house

full of the dust of years, red with the hearts of cedar

and as full of whorls and rings and whispering deep-grain tales.

Its shade will be Pegasus in leadlight.

Hooked on the story, you made a dozen

trying to get the horse alive and leaping

and he does, galloping off the mount,

every feathery wing-flutter a word,

a line to hold us above the rush of earth flying.

But we need few of those buoys.

We talk the language of lime tree, lawn and basil,

of boats past and fish to come,

of the untangled lines we hold now in our hands

when the past was so littered with knots and fraying cloth;

with the dead eye of the fish cold, you gasping for breath

against the hopeless arguments of youth.

Look at us, at 88 your life brim-full

and me in the middle of years, 
our own visions tossed around

in an autumn too warm for comfort,

sprawled on the deck for lunch, glass in hand

the sea spread before us, a delicate

glittery window into the blue of everything.

Old jokes, old memories are turned and papered smooth as time and just as quick, both coming, and going.

Everything has been this rich for nearly two decades,

Mum gone to ash and the polish on her flaws

working away all indented scars, all bruised hurt.

Last night the sea was silver lame

like Merle Oberon would slink in,

and clouds were pushing up in meringue crests above the scarp

or cream on top of sponges she made for endless fetes.

We still walk her track along the shine of rocks to Shelly cove

and I sit, as she did, to run my fingers through the grit,

raking over all the small things the sea rolls up

collecting the moment.

Look at us - really Dad - each likely to stumble now, each with our hand already cupping the elbow beside, faces glistening with the salt that wind and waves

might bury us with, or wear us away.

We part these days always anxious, in hope of meeting again soon and I journey back south to my sleep in that boat of a bed you made me,

timber gleaming in the dark night, its centre a dolphin plunging into indigo glass waves,

a blue topaz you cut, set like a third eye into the bed-head 'so I'll always be there to look out for you', you said.

Dr. Robyn Rowland AO has published 9 books, six of them poetry. Silence \& its tongues (Five Islands Press, 2006) was runner up for the 2007 ACT Minister's Judith Wright Poetry Prize. She has won the Catalpa Poetry Prize and overall Writers Prize from the AustralianIrish Heritage Association, and the Jean Stone Poetry Prize. An Honorary Fellow, School of Culture and Communication, University of Melbourne, Robyn was previously Professor of Social Inquiry at Deakin University, retiring in 1996 


\section{Peter Nicholson:}

\section{Final Proofs}

Shed skins chucked, Calling cards to entropyHave I known you well enough, Stroked your syntax carefully Nor bruised your music willingly? Moment of abandonment Flickers as this final draft Is cast upon that further shore Whose islands glimmer metaphor, Ignorance and time's disdain. Whatever fault or satisfaction Links that crossing, let it go, The troubled best of my intent Whose hand assigns to jailing print Words for an indemnity.

\section{Abandoned Cricket Pitch}

An empty cricket pitch, Dust blowing from inland, A bird ascends smudged air Near colours cracked from stone.

Night bends;

Opal colours plummet space As the paralytic moon Genuflects its emu eye.

Have you failed?

Loved the pitch you harness here Or lost the old simplicity That camped beside the creek?

Dust behind the ranges quickens, Pillars spinning nearer youFar from ocean's rearing haze, Pitch is cracked, but rain is due. 
Peter Nicholson was born in 1950 and was educated at Armidale Teachers College and Macquarie University. There is an introduction to his work at peternicholson.com.au 


\section{Diane Fahey:}

Garden Walk

A stand of ivory irises, gold-tongued, cinerarias in royal velvets.

We pass my father's camellia tree, its yield of coral cups the first since his death.

Across years. You call it 'the miracle tree'.

Nearby, this mandala bloom: a petalled

frame round the abounding heart, heart-red.

I think of these hopeful, circumspect days

as your harvest won from pain endured;

this garden your rich share of the forms life takes

in its quest for beauty in survival.

At dusk, whether we listen or not, bird songs

will wreathe this old house in splendour. Later,

lotus-stars on a black pond of unknowing.

\section{Before the heat}

Down the garden, letting the dawn wind travel through my body, transport me with freshened sight to here. I pluck weeds, skirt the pumpkin vine ramping out from the young apple tree, tapping its strength. A door slams. Inside I find my mother beautifully asleep, lying fish-shaped across her bed, wrapped in a beach towel the greens of algae and leaf; deep in her hip-bone, the infection we live to outwit.

The touch lamp is on: light answerable to fingertips. All night, cool air streamed in. Soon I'll shroud each window, draw up the moat bridge, seal us inside this peace we have made. 


\section{Breath}

Sleeplessness. At dawn, soft rain, the birds, and music - Pachelbel's Canon played over and over to soothe a mind still fazed after a dizzy waking at one a.m. an alarm call to check on my mother. With practised silence I opened her door, in the quarter light leaned towards her face, porcelain-pale, the strength of those fine bones, to hear a breath. The same life-tide that swept us apart has brought us to this grateful, elegaic love, the hub we turn on Demeter and Kore becoming each other, held in a graced affinity between loss and loss. Twilight summer.

Diane Fahey is the author of eight poetry collections, the most recent being Sea Wall and River Light (FIP Press), a series of sonnets about the coastal town of Barwon Heads in Victoria, Australia. A verse novel, The Mystery of Rosa Morland, was published by Clouds of Magellan in 2008. Her New \& Selected Poems will be published by Puncher \& Wattmann late in 2010. Diane has won various poetry awards and literary fellowships. She holds a B.A. and an M.A. in Literature and a PhD in Creative Writing for her study, 'Places and Spaces of the Writing Life'.

'Breath' and 'Garden Walk' have never been published before. With thanks to the poet. 
Horst Prießnitz: Australian literature's embeddedness in oversea's literature finally acknowledged. Pierce, Peter, ed. The Cambridge History of Australian Literature. Cambridge: Cambridge UP, 2009. Hb. X, 621 pp. $£$ 95.00. ISBN 978-0-521-88165-4.

\begin{abstract}
A s Peter Pierce points out in his introduction, as far as Australia is concerned, an emphasis on nation-making, particularly in the conflation of political and literary chronologies, coloured literary historiography for generations. One of the outstanding features of the CHAL is that it is not another contribution to the national project, but a collection of narratives in which what is 'national' and 'Australian' is debated throughout its individual chapters.
\end{abstract}

The table of contents suggests a chronological reading of the twenty-four essays by diverse hands within a tripartite time frame. 'From European Imaginings of Australia to the End of the Colonial Period' (i. e. 1900) is devoted to the examination of anticipations of terra australis, the complex transportation of the cultural baggage of the mother country into the colony, the literary beginnings, early writings by Indigenous Australians, colonial poetry and fiction and the influence of British Romanticism on the colonial perception of the landscape, nature and the 'noble savage'. 'From the Late Nineteenth Century to 1950' covers Australian self-perceptions, the early histories of the short story, drama and theatre, the advent and impact of modernism in poetry, the development of fiction, and Australian responses to the magnetic lure of imperial London. 'From 1850 to Nearly Now' deals with institutional changes in the field of Australian literature, the histories of the theatre, of the short story and the novel from the mid-twentieth century onward, post-1950 Australian poetry, its groups and mavericks, and what has been termed 'international regionalism'. In between the second and the third parts there is a section, entitled 'Traverses', which links the colonial literary world with the post-World War II period by 
surveying the development of children's books, Australian images of Asia, autobiographical writing and historical fiction.

This summary says little about the intellectual U-turn and the special viewpoint of the CHAL, which can be circumscribed as follows: (1) It demonstrates that there is a prevailing dialectic among the works and authors dealt with to forge a distinctively Australian literature and the deep connections to the British and European cultural heritage. (2) At the same time it emphasises the old truth that 'no man is an island, entire of itself', but 'a piece of the continent, a part of the main' - an insight that has been strengthened by recent critical studies which argue that a purely insular and inward-looking approach to literary history is inadequate for an understanding of how a national literature is formed when there are influences that go beyond the boundaries of a nation. It is not that earlier histories have not recognised the numerous foreign footprints on Australian shores, but never before has a literary history been more willing to acknowledge Australia's embeddedness in overseas literary currents and socio-cultural developments. (3) Thus it translates into literary historiography what David Cannadine in his Orientalism (2001) postulates as a general principle of both political and cultural historiography, namely that there can be no satisfactory history of Britain without the empire, and no satisfactory history of any part of the empire without Britain. By stressing the interconnectedness between social, cultural and literary visions of the metropolis and the periphery, and the structures and systems that unified and underpinned them, the CHAL seeks to write the cultural history of Britain into the literary history of Australia and the literary history of Australia back into the cultural history of Britain. This innovative approach becomes fully evident when one regroups the chronological sequence of chapters in a functional order. Roughly speaking, the essays fall into three categories: (1) Explorations of literary beginnings, (2) histories of literary genres and forms, and (3) programmatic reorientations of literary historiography.

Elizabeth Webby traces the material foundations of the nascent Anglo-European literary culture from the availability of books to the influence of educational institutions including Mechanics' Institutes 
and universities, all of which contributed to the rapid growth of literacy in the colony and made the new country the largest market for books from 'home', i.e. books by British, American, classical and European authors. Penny van Toorn discusses Aboriginal literacy, i.e. the various modes of graphic signification practised by Indigenous Australians in rock paintings and engravings, and the consequences of the arrival of the British in 1788, which did not trigger off a shift from Aboriginal orality to European literacy, but rather an entanglement between radically different reading and writing practices.

Given the quantity and quality of the novel, it is little wonder that four essays follow the genesis and growth of the genre. Tanya Dalziell maps fiction up to 1900 , i.e. convict or captivity narratives, descriptions of colonial life for readers at home, emigrant handbooks, travel books depicting a future antipodean Arcadia, explorations of domestic spaces in which colonial women work and live, diaries of inland explorers, heroic adventure stories, scientific fictions and even fictional efforts, often embedded in popularised pseudo-scientific racial theories, to erase Aboriginals from colonial view. Taking Pascale Casanova's The World Republic of Letters [1999] (2004) and Graham Huggan's Australian Literature: Postcolonialism, Racism, and Transnationalism (2007) as points of departure, Robert Dixon insists that any historian of Australian fiction between 1890 and 1950 must now take an international perspective, since having a novel published throughout this period almost always meant being published first in London and New York. According to Dixon, cosmopolitanism and nationalism have to be seen as the two conflicting forces which shaped the values, styles and loyalties of the period and coexisted simultaneously. As Susan Lever illustrates, the post-1950 novel has discovered the modern city as a site of political power struggles and betrays Patrick White's influence - his pushing fiction to a mythopoeic, metaphysical, and religious dimension. Fiction of the 1970 s and later is shaped less by British than American, European and Latin-American experiments: verse novels and mixed forms such as the anatomy or discontinuous narrative stories by male and female writers dominate the scene. Richard Nile's and Jason Ensor's account of the novel, the implicated 
reader and Australian literary cultures is an incoherent piece of criticism. Patching together bits of half-digested reader-responsetheory, trivia and statistics, it tries to convey the message that it is impossible to appreciate the full history of Australian fiction without recourse to the ongoing importance of the English language, that literature is not what is written on the page, but how writing is read, and that the novel has become Australia's essential literary form and will remain so into the next century.

Claire Bradford surveys children's books from the middle of the $19^{\text {th }}$ century to the present days, taking the first book for children, $A$ Mother's Offspring to Her Children (1841) and Shawn Tan's The Arrival (2006) as bookends. David McCooey's excursion into what he calls 'the autobiographical mode' identifies a whole cluster of texts as belonging to this form of self-representation: memoirs, diaries, letters, autobio-graphical life writing, testimonial writing and autopathography. Its renaissance is attributed to a set of crises, of the body, of the nation, of identity, of history and of faith. Without arriving at a satisfactory clarification of what is meant by ' the intersection of history and fiction', Brian Matthews compares the reception of the early volumes of Manning Clarke's A History of Australia and Kate Grenville's novel The Secret River. Despite the author's subsequent model analyses of selected novels and short stories, the reader is left in the dark about which general conclusions he/she is to draw from the fact that the historian was charged with being too literary and the novelist with being too historical.

Bruce Bennett and Stephen Torre outline a short history of the short story. While Bennett focuses on the pre-1950 decades, revisions of the legend of the '90s, international influences on the Bulletin school, literary versions of Australia's pasts, Torre foregrounds the financial, ideological and editorial complexities of the publishing world in the second half of the $20^{\text {th }}$ century and characterises short story anthologies which construct their content in a variety of ways, displaying a globalised awareness of, and sensibility to, international tensions or modes of writing. 
Linking up with the final section of Elizabeth Webby's essay, Peter Fitzpatrick and Katharine Brisbane complete the survey of Australian theatre and drama. Fitzpatrick points to the fact that the disjunction between theatre as a public entertainment and drama as a solitary art given to the construction of a distinctively Australian voice lies at the heart of the debate about the state of Australian theatre from the middle of $19^{\text {th }}$ century to the middle of the next. Brisbane describes the post-World War II American successes on the commercial stage, the creative energy which grew out of the public protest against Australian involvement in the Vietnam War, the rise of the New Wave and its literary representatives, and the emergence of experimental and minority theatre groups.

While the history of the novel seems to have become an international success story, the development of poetry is one of decline from a once favourite public to a minority and private art form. According to Vivian Smith, the two main currents in Australian colonial poetry were the popular, based on the songs, ballads, sea shanties and simple narratives brought here by convicts and settlers; the other stream was learned and literary, drawing on the whole European cultural tradition and employing language which is consciously hightened and refined. Smith shows that colonial poets were consistently responsive to major political and historical events in Italy, the Crimea, Poland, New Zealand, the United States and never lost their sense of connectedness to Europe and the rest of the world At the beginning of the period (1890 - 1950) covered by Peter Kirkpatrick, poetry was still commonly published in newspapers, spoken in suburban parlours, in schools, in theatres and on concert platforms. By the middle of the $20^{\text {th }}$ century newspapers rarely published poetry and, outside festivals or the occasional radio programme, its performance was virtually extinct. Modernism and its rise to cultural authority after World War I played an obvious role. Free verse did not lend itself to public recitation in quite the same way as popular ballad metres, and since a lot of modern poetry was designed to be ambiguous, it required close, silent study in order to yield up meaning. Since the rebellion of what was to become known as the Generation of the '68 against the wellmade, rhyming and stanzaic poem, Dennis Haskell shows, the 
dichotomy between two different senses of poetry has sharpened: one that, following modernism, values intellectual sophistication and complexity, and one that values immediate, less intellectual than emotional response. The debate about the question of just what poetry is or should be, has led to the situation that, in terms of sales, money and public attention, poetry has become something like an endangered species in a zoo, i.e. in the English Departments of tertiary institutions. What seems to have been intended as a guided tour, turns out to be a chaotic ramble through the landscape of contemporary Australian poetry. John Kinsella's highly subjective cartography and evaluation of groups and mavericks leads to the meagre result that there are schools and coteries as well as isolated individuals who refuse to be herded together and who work against the grain.

The great majority of essays so far are informative and highly stimulating. By far the most thought-provoking contributions are to be found among the category of histories-cum-reorientations, all of which can be understood as extrapolations from, or variations of, Robert Dixon's seminal argument that any approach to Australian literary history should adopt an international perspective. Ken Stewart discusses British, especially English literature, ideas and literary conventions and their paramount importance for colonial writing and possible repercussions of $19^{\text {th }}$ century colonial literature in British culture. He illustrates pre-settlement images of the imaginary terra australis, the demands that Australia made on English words which led to a semantic heteroglossia resulting from reshaped British negotiations with local topography, climate, flora, fauna and Indigenous cultures, the colonial appropriation of the conventions of Popean and Swiftian satire, the influence of Southey and Wordsworth, J. S. Mill, Thomas Carlyle, John Ruskin, Charles Dickens, the Immortal Bard, Gilbert and Sullivan and Oscar Wilde. It is a pity that Stewart had no space to uncover the traces of Shelley, Trollope, George Eliot, the Irish balladists and Robert Burns. What makes this essay so noteworthy is that Australia's negotiations with British texts, ideas and conventions are no longer perceived as cultural enslavement but as creatively inescapable in the formation of a colonial literature. 
The question whether the years between 1788 and 1860 were Australia's Romantic Period or the aftermath of Neoclassicism is one that is hotly debated. While some critics, among them Richard Jordan, Peter Pierce and Paul Kane, argue that the Romantic period proper seems to have missed Australia altogether - that Australia, as Kane put it, was some kind of Rip van Winkle, falling asleep as a neoclassicist and awaking as a Victorian - Richard Lansdown offers an alternative view. His thesis is that Romanticism was not only a European phenomenon but a sea change in the Western world that reached not just the shores, but the very centre of the Australian continent. From the earliest days, he illustrates, Neoclassicism and Romanticism coexisted simultaneously, but the perceptions of the landscape, nature and its Indigenous inhabitants were clearly shaped by British and European Romantic ideas.

Peter Pierce's attempt to rediscover and redefine what was, and was not, Australian in the literature of the decades between the world wars is another illuminating example of historiographical reorientation. The experiences on the battlefields of war-torn Europe are seen as a significant impetus for a parochial, inward-looking gaze. At the same time the metropolitan culture, open to the outside world, remained of vital importance, as can be proved by the fact that so many artists and writers left Australia to live in Britain or Europe. Those who stayed at home sought to make discoveries in and about their own country, whether by physical expeditions into inland and other remote regions, or by journeying back to the pioneering past. What Pierce is saying is that the literary attempts to discover the mysteries and the 'heart' of Australia in a kind of creative impulse was simply a profound reaction to 'internationalism', i.e. to the moral corruption of old Europe during the Great War.

Peter Morton looks into the fascination the metropolitan culture of Britain, especially of London, had on Australian writers and artists between 1880 and 1950. The sheer power of English cultural hegemony, especially over the literary arts, was overwhelming. Stay-at-home writers took their nutriment from Britain: they could read nothing, write nothing, criticise nothing, without being 
reminded that their literary culture was derivative, stuck fast in the relationship of colony to metropolis. As a consequence, Morton points out, colonial writers could not help being international by having to compete with the literary markets of Britain. Constructions of positive or negative visions of London and Britain depended on individual successes or failures there. It was only after World War II that the dominance of Britain was replaced by the attractiveness of the United States, which seemed to offer writers the greatest congeniality, the most relevant models, and the best opportunities and rewards if they lived or published there.

Australian writers not only looked to the West, but also to the Far East, later renamed the Near North. They did so from an entirely British perspective. As Robin Gerster observes, colonial Australian writers subscribed to prevailing imperial ideologies in depicting Asia not only as essentially different, but also as backward, barbarous and in dire need of Britain's benign civilising influence. Australian Asian travellers of the $19^{\text {th }}$ century regarded the region with suspicion if not with what Gerster calls Asiaphobia. The opposition to the Vietnam War gave rise to a new understanding of Asia. Western visitors created the myth of the Spiritual East, which became interchangeable with that of the Sensual East. Women writers of the 1980 s responded to the sexual appeal with constructions in which Asia is a sexual promise, a site for the reinvigoration of female lives physically and spiritually in dreary male-oriented Australia. Male writers responded to what they saw as Asia's metaphysical possibilities; Asia became associated with personal fulfilment and enlightenment. This idealisation has become the satirical target of contemporary Australian fiction.

Philip Mead tries to reconcile the two contradictory streams in Australian literary history, the regional/local or parochial and the transnational/ global or cosmopolitan. The hunger for an Australian civilisation was seen as essentially bound to the establishment of a nation. However, what a nation means in terms of history, culture and symbols, has come under pressure from internal differences over narratives of nation, as well as from the socio-economic and cultural forces of globalisation. As Mead points out, as a reaction to 
both trends post-national Australian literary studies and historiography have been moving in two directions: towards transnational comparisons and contexts, and towards re-readings of the local. Mead claims that the remarkable flowering of regionallyrooted literary cultures in recent years is not an accidental phenomenon, but a response to the impact of internationalism which tries to capture what he calls 'international regionalism' and in which he sees future possibilities for critical regional reading and for a revision of theories of location.

David Carter explores the institutional changes and crises in the field of Australian literature as far as publishing and cultural policies are concerned. The rapid growth of local publishing and the gradual emergence and expansion of new and diverse institutions dedicated to Australian books and authors from the 1950s onward, helped to define Australian literature through a set of relatively autonomous sites in universities, publishing houses, critical studies, bookselling and professional associations. In the new century, however, some of these achievements seem no longer secure. Although a mature infrastructure has been established, Carter summarises, it exists within a newly globalised international literary system which poses once again some of the recurrent questions for Australian culture: its independence, its 'national' significance, and the role of literature in general. The dramatic collapse in the publication of Australian books and the profound change in academic literary studies since the 1990 s point to a situation for which the term crisis does not seem inappropriate. Carter's diagnosis raises the question whether this crisis has its roots in purely economic factors, in falling booksales and new preferences among readers, in the global competition of regional literary markets or the ideology of neoutilitarianism as propagated by advocates of the market-smart forprofit university rather than in a radical revision of fundamental assumptions about the nature of man, his creative capability to design fictional worlds, and the social, cognitive and ethical implications.

Although this problem is not (and cannot be) assessed, let alone solved, in a single contribution to a literary history, the CHAL must 
be said to represent an overdue aggiornamento of Australian literary history in that it places the country on the global map of world literature in English as a multivocal, but dominantly Anglo-European literary culture in a state of flux. It exposes the fragility of the concept of a homogenous national culture in that it no longer offers a unified and authoritative vision of Australia's literary history, but a many-faceted collection of stories which could be augmented by accounts of 'How Indigenous Australians perceive their country'; 'Australia's America'; 'Literary fakes and hoaxes'; 'Changing perceptions of the artist/writer/poet'; 'Utopias, dystopias, eco(dys)topias'; 'Religious controversies'; 'SF and transhumanism'. It reminds its readers that a profound knowledge of British and American cultural history is required to discern and evaluate the many reverberations, intertextual relations, responses and affinities which distinguish the literature of the fifth continent. It provides exciting revaluations of familiar works, authors and periods. It gives the overall impression that somebody has opened a window onto the outside world, let in a breeze of fresh air to drive away the staleness of four decades of parochial 'national-identity mongering'. Had this history been available thirty-five years earlier, it would have made things much easier for those who fought many a lonely battle to establish a 'new literature' within the canonical curriculum of English and American literary studies. 
Adrian Hyland: Outback Bastard. suhrkamp taschenbuch 4110, Frankfurt am Main, 2009, 366 S., ISBN 978-3-518-46110-5. Australische Originalausgabe 2006, Diamond Dove, Text Publishing, Melbourne. Rezensiert von Corinna Erckenbrecht (Köln)

ie Wüste lebt! - möchte man nach der Lektüre dieses
Kriminalromans, in dem es genretypisch natürlich auch ein paar Tote gibt, unwillkürlich ausrufen. Denn vom furiosen Auftakt bis hin zum fulminanten Schlussakkord tritt solch eine Fülle von Personen auf und entrollen sich in atemberaubender Dichte solch spannende Entwicklungen, dass man kaum noch hinterherkommt. Spirituelle Anführer, Viehbarone, Zauberer, Goldsucher, Ingenieure, Politiker, Anwälte, Wildhüter, Anthropologen, Spurensucher, Prospektoren, Minenarbeiter, Weinbauern, Geschäftsleute, Mechaniker, Schlachter, Wünschelrutengänger, Polizisten, Wasserwerker, Gemeindemanager sowie die vielen verschiedenen Charaktere einer Aboriginal community namens Moonlight Downs - sie alle sind in einem kunterbunten Kaleidoskop in diesem Krimi miteinander verbunden. Das Ganze spielt sich ab vor dem Hintergrund des angestammten Siedlungsgebiets der "Warlpuju" - unschwer als die Warlpiri zu erkennen - irgendwo in der zentralaustralischen Wüste mit ihren vielen spirituell angereicherten Orten, mit Totemzentren von unterschiedlicher Bedeutung für die einzelnen Personen. Kam hier nicht einst in mythischer Vorzeit die Drosselstelze vorbei und rastete am Wasser? War es nicht dort, wo damals ein Schwarm Zebrafinken landete und ein paar Grassamen aufpickte, bevor er weiterflog? Das Land ist gesättigt mit den Taten der totemistischen Ahnen aus der Traumzeit, ihren Wanderwegen und Liedzyklen. Ein Totem ragt dabei besonders heraus, wie wir im Verlauf des Buches erfahren, das Totem(zentrum) der Diamanttaube. Ein kleiner grauer Vogel mit Sternen auf den Flügeln und Ringen um die Augen. Daher heißt das Buch im englischen Original auch Diamond Dove, vom deutschen Verlag wenig passend mit Outback Bastard betitelt. 
Adrian Hyland, der Autor dieses Buches, der viele Jahre in Aboriginal communities nördlich von Alice Springs gelebt und gearbeitet hat und jetzt an der La Trobe University in Melbourne unterrichtet, hat ganze Arbeit geleistet. Nicht umsonst wurde sein Buch 2007 mit dem Ned Kelly Award für das beste Krimidebüt ausgezeichnet. Der Sydney Morning Herald bezeichnete das Buch als unputdownable, was man nur bestätigen kann. Überwältigt von den verschiedenen Charakteren und Szenarien folgt man atemlos der Handlung.

Emily Tempest, die Romanheldin, kommt in die Aboriginesiedlung zurück, in der sie als Kind aufgewachsen ist. Als Tochter eines weißen Farmmitarbeiters und einer Aboriginemutter wuchs sie zusammen mit den Aborigines von Moonlight Downs auf. Ihre Schule war der Busch und die sozialen Verhaltensregeln der "Meute" von Moonlight Downs. Schon als Kind hörte sie viel über die "Träume", die mythischen Überlieferungen des Stammes. "Träume - Jukurrpa - sind den Warlpuju alles", schreibt der Autor kenntnisreich: "Orientierung, Mythologie, Datenbank, Liederzyklus, aber auch Verhaltenskodex." (S. 27). Unter allen Personen in Moonlight Downs verbindet Emily besonders mit ihrer gleichaltrigen Freundin Hazel eine tiefe Beziehung. Gemeinsam sind sie aufgewachsen, gemeinsam haben sie das Land durchstreift und ihre großen und kleinen Geheimnisse miteinander geteilt. Aber Emily, neugierig und respektlos gegenüber den Ältesten, steckte immer wieder ihre Nase in Angelegenheiten, die sie nichts angingen, weil es sich zum Beispiel um Zeremonien an den geheimen Orten der Männer handelte. So eckte sie in der Welt der Aborigines immer wieder an. Als ihr Vater, Mechaniker auf der Viehstation von Moonlight Downs, dann auch noch seinen Job verliert, weil der neue Besitzer das gesamte bisherige Personal vergrault, ist es mit dem freien Leben in der Wildnis vorbei. Da ihre Mutter schon lange verstorben ist und ihr Vater das Land verlässt, um sich als Mineraliensucher und Goldschürfer mit einer vielversprechenden Schürfpacht selbständig zu machen, kommt Emily in ein Internat in Adelaide. Danach reist sie ziellos in der Welt umher.

Schuldgefühle, sich damals daneben benommen und schließlich ihre Freunde Hals über Kopf verlassen zu haben, ohne sich jemals wieder zu melden, bestimmen Emilys ambivalente Empfindungen, als sie eines Tages wieder in die Aboriginal community von Moonlight 
Downs zurückkehrt. Die Gruppe hatte nach der Vertreibung durch den neuen Besitzer zehn Jahre in Bluebush gelebt, einem trostlosen Minenstädtchen, in dem sich "Desperados aller Art" (S. 61) zusammengefunden hatten. Nach der erfolgreichen Einklagung ihrer Landrechte in Moonlight Downs war die Gruppe endlich doch wieder auf ihr angestammes Land zurück gezogen. Emily wird von dem spirituellen und sozialen Oberhaupt der Gruppe, Lincoln Flinders, freudig begrüßt und von allen freundschaftlich in die Gemeinschaft aufgenommen. Sie ist trotz allem doch eine von innen geblieben. $\mathrm{Zu}$ dumm nur, dass Lincoln kaum zwei Tage später mit gebrochenem Genick und herausgeschnittener Niere tot im Gestrüpp liegt. Alles deutet auf einen Ritualmord hin, denn die Entfernung einer Niere gehört zur Methode eines Zauberers oder Hexers, der Übeltäter wegen Vergehens gegen die Stammesgesetze bestraft. Gleich am Tag ihrer Ankunft in Moonlight Downs war auch Emily bei einem Jagdausflug im Gelände Zeugin geworden, wie der Zauberer, Beherrscher der Kristallsteine und Hüter der Gesetze, Blakie Japanangka, Lincoln Flinders massiv angegriffen und mit Vorwürfen überhäuft hat (und dies später im Camp noch einmal wiederholte), da Lincoln - ja, was eigentlich angeblich ungestraft zugelassen habe. Um diese spannende Frage dreht sich in der Folge der ganze Krimi, denn sie ist der Schlüssel zu Lincolns Tod. Die örtliche Polizei nimmt ihre Untersuchungen auf, ist aber zu einfallslos und faul, als dass sie mit mehr als der These vom Ritualmord aufwarten könnte. Daher beginnt Emily, auf eigene Faust zu ermitteln.

Immer wieder kommt es dabei auch zu langen Gesprächen und Ausflügen in die Umgebung mit ihrer alten Freundin Hazel, mittlerweile die Gesundheitsbeauftragte der Aboriginal community von Moonlight Downs. Sie wurde seinerzeit auf die Schnelle mit einem wesentlich älteren Mann verheiratet, der bereits eine Frau hatte; später schloss sich noch die Witwe des verstorbenen Schwagers an. So besteht Hazels Familie aus zwei Mitfrauen und etlichen Kindern, die aber auch nicht alle von diesem einen Ehemann stammen. En passant lernen wir hier also, wie Polygynie und Levirat („Schwagerehe") bei den Aborigines funktionieren und aus welchen Personen eine Aboriginefamilie, im Gegensatz zur abendländischen Kleinfamilie, zusammengesetzt ist. Anlässlich von Lincolns Tod lernen wir auch spielend alle Trauertabus und -zeremonien kennen, die nun folgerichtig beginnen. All das bildet wie selbstverständlich 
den Hintergrund aller weiteren Unternehmungen von Emily, die keine Ruhe bei ihren Ermittlungen gibt. War Blakie der Mörder, jener Hexer mit seinen Kristallen und teuflischen Verwünschungen, der es bald nach der Tat ohne Probleme verstand, im Busch abzutauchen und sich den Polizeibeamten zu entziehen? Oder war es der Viehbaron Earl Marsh, der unangenehme Nachbar von Moonlight Downs, dem die wandernden Aborigines und deren streunende Hunde ein Dorn im Auge sind - ganz zu schweigen von den Landrechten, die die Aborigines erfolgreich für sich erstritten haben? Oder was ist von diesem windigen "Distriktmanager für regionale Entwicklung" zu halten, Lance Massie? Emilys Ermittlungen gehen bald in alle Richtungen.

Die wichtigsten Hinweise kommen jedoch schließlich aus der Welt der Träume - und von Hazel. Lincoln war ihr Vater, und sie kennt alle seine spirituellen Beziehungen zu dem Land, alle seine wichtigen und weniger wichtigen Totems. Ja, er war eine Drosselstelze, er war auch ein Zebrafink - vor allem anderen war er aber eine Diamanttaube, so wie seine Tochter Hazel auch. Es ist „ihr Medium, ihr Buschname, ihre Brücke in die andere Welt", eine "Spiegelung der Seele". (S. 355, 359). Hazel ist künstlerisch begabt und legt nach dem Tod ihres Vaters eine Serie von Portraits von allen seinen Totems und Totemzentren an - somit seine Geschichte malend, wie sie sich aus dessen spiritueller "Laufbahn" ablesen lässt. Der Hauptort der Diamanttaube ist Karlujurru, das Zentrum des Traums und der Songline schlechthin, wo die mutige Taube einst mit einem mächtigen Teufel rang und inn schließlich durch einen Erdrutsch erledigte. Die Macht der Diamanttaube siegte, und sie wird auch soviel sei schon verraten - Emily zum Sieg verhelfen. Im atemberaubenden Showdown in Karlujurru wird der Mörder Lincolns schließlich zur Strecke gebracht.

Ein großer Verdienst dieses Buches ist es, dass man auf unglaublich spielerische Weise in die komplexe Glaubens- und Gedankenwelt der Aborigines hineingezogen wird. Der ethnologische Fachbegriff des Polytotemismus, sonst in wissen-schaftlichen Publikationen der Experten kompliziert erklärt, erscheint im Handlungszusammenhang dieses Romans einfach, logisch und folgerichtig. Die Lebens- und Ernährungsweise der Ureinwohner in der Wüste, wo ihr geschulter Blick es innen jederzeit erlaubt, der Natur etwas Essbares 
abzugewinnen, erschließt sich ebenso leicht und selbstverständlich. Aber auch die fragile Realität nichtsesshafter Wanderer wird verständlich. Zunächst vom neuen, arroganten Farmbesitzer von ihrem Land vertrieben, braucht es viele Jahre, um das Stammesland vor Gericht wieder zurück zu erstreiten. Gerade erst war Moonlight Downs zu neuem Leben erwacht und noch nicht alle Mitglieder der Gesellschaft hatten hier ihre Zelte wieder dauerhaft aufgeschlagen. Da stirbt Lincoln, der einflussreiche Anführer der Gruppe. Der Ort muss wegen der Trauertabus verlassen werden. Die Gemeinschaft zerfällt. Die gerade erst wieder gegründete community zerstreut sich in alle Winde. Die Welt ist in Unordnung geraten. Die meisten Warlpuju ergeben sich dem Alkohol in Bluebush. Erst durch Emilys und Hazels Einsatz kann die Welt wieder ins Lot gebracht werden.

Alles in allem handelt es sich um starkes, lesenswertes Buch, das über weite Strecken gut übersetzt ist, das aber an manchen Stellen die spezifischen australischen Gegebenheiten nicht ganz treffend erfasst. 


\section{Lorraine McGee-Sippel: Hey Mum, What's a Half-Caste?} Magabala Books Aboriginal Corporation, Broome 2009. 290 Seiten, 1 Karte, 35 Fotos, Paperback, ISBN 9781921248030. Rezensiert von Elisabeth Bähr, Speyer

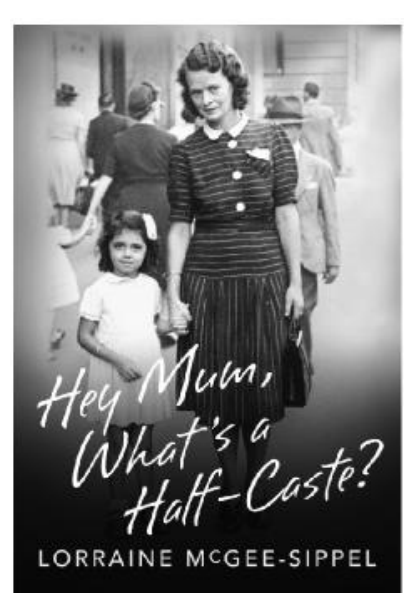

Lorraine McGee-Sippel (geb. 1943), die seit 1991 Gedichte schreibt (siehe das Beispiel "Belonging" am Ende dieser Besprechung), legt mit diesem Buch ihre Autobiographie vor. Umschlagfoto und Titel des Buches scheinen keinen Zweifel über das Thema aufkommen zu lassen: Ihre Mutter ist Weiße, sie selbst hat eine dunkle Hautfarbe, ist also indigen. Und dennoch taucht erst auf Seite 80 des Buches das Wort Aborigine zum ersten Mal auf. Wie kann das passieren?

Im Alter von acht oder neun Jahren, als Lorraine McGee-Sippel mit ihren Eltern auf einer Schaf- und Viehfarm im Hunter Valley lebte ihre Mutter arbeitete im Haushalt, ihr Vater als Gärtner -, wurde sie von einem Mitschüler beschimpft: "You half-caste." Sie kannte das Wort nicht, fragte ihre Mutter und erhielt keine Antwort. Sie begann, die Fotoalben der Familie genauer anzusehen und stellte fest, dass sie anders als die gesamte Verwandtschaft aussieht. Der aufkeimende Verdacht, sie könnte adoptiert sein, verursachte große Unsicherheit, weil ihre häufigen Nachfragen von ihrer Mutter stets mit missmutiger Geste abgewehrt wurden. Denn Kinder sollten zwar sichtbar, aber nicht hörbar sein; insistierende Fragen waren verpönt. So war das Verhältnis zur Mutter konfliktbeladen, zum Vater weitaus besser; allerdings war die Mutter die bestimmende Person in der Familie.

Als endlich eine Leugnung der Adoption nicht mehr denkbar war, wurde sie dem damals zwölfjährigen Kind in einer Weise bestätigt, die man als die "harte Liebe" der 1950er Jahre bezeichnen könnte. Geboren aus Armut - die Eltern besaßen zeitweise nicht einmal die Möbel, in denen sie lebten -, Enttäuschungen, Krankheit und den Konventionen und Tabus dieser Zeit war ein liebevolles, erklärendes, die tiefe Verunsicherung auffangendes Gespräch nicht möglich. Ganz im Gegenteil wurden dem Kind noch familiäre Ereignisse erzählt, die zu zusätzlichen Selbstzweifeln führten. 
Vollkommen ohne Rücksicht auf ihr eigenen Wünsche - üblich für diese Zeit - wurde Lorraine McGee-Sippel ein Jahr vor Beendigung der Primary School ohne vorherige Vorbereitung oder Erklärung nach Sydney zur Schule geschickt. Sie hatte bei einer ungeliebten Tante und einem Onkel zu leben, der sie sexuell belästigte, ein Vorgang, den die Mutter nicht der Auseinandersetzung für Wert befand. Ihre gesamte Kindheit und Jugend verlebte sie in Armut mit den entsprechenden Demütigungen, die sichtbare Besitzlosigkeit nach sich ziehen.

Die folgende Szene, die sie mit 25 Jahren erlebte, ließ - wie sie selbst schreibt - ihr Leben auseinanderbrechen.

I had just told my parents the good news that I was getting married. Dad cleared his throat, giving no warning of what was to follow. 'Toots...' he began. 'When we collected you from Scarba Home at Bondi, the social worker said we had to tell you something before you got married. Toots, your mother was white, but your father was black. He was a Negro. The social worker said we'd be sorry for taking you, and that you'd have to be checked out by a doctor before you had kids. She said you could have throwbacks and your husband might think you'd been playing around.'

Ihr Traum zu heiraten und vor allem, Kinder zu bekommen, ist für sie damit vorerst unmöglich zu verwirklichen. Sie durchlebt über Jahre hinweg immer wieder Zeiten voller Selbstzweifel bis hin zur Depression.

Als sie jung war, verspürte sie den heftigen Wunsch, ihre leiblichen Eltern zu finden. Später als Erwachsene verflüchtigte er sich zeitweise, denn aufgewachsen bei weißen Eltern in einer weißen Umgebung hatte sie die Vorurteile gegenüber dunkler Haut selbst verinnerlicht und verstand die Anspielungen auf ihr "Anderssein" nicht als rassistisch. Erst als ihr bewusst wurde, dass sie nur dann zu einer geschlossenen Persönlichkeit finden und offene Beziehungen zu anderen Menschen eingehen würde, wenn sie ihrer Wurzeln fände, begann sie mit der Suche.

Sie entdeckte die Adresse inrer Mutter, als sie selbst 38 Jahre alt war, und glaubte immer noch, ihre Mutter sei Weiße und ihr Vater 
Afroamerikaner. Aus heutiger Sicht wirkt es durchaus verstörend, dass sie zunächst Abneigung dagegen empfand, eine Aborigine zu sein, als sie schließlich erfuhr, dass alle ihre Vorfahren mütterlicherseits indigen sind. Doch selbst zu Beginn der 1980er Jahre gehörte die indigene Kultur nicht zum Mainstream und war in den Medien nur mäßig präsent. Die indigene Bevölkerung war weitgehend unsichtbar und ihre politischen Organisationen nicht überall hörbar; zumindest konnte man in der weißen Gesellschaft leben, ohne mit indigenen Angelegenheiten konfrontiert zu werden.

Auch nachdem Lorraine McGee-Sippel herausfand, dass sie eine Yorta Yorta ist, dauerte es noch einige Zeit, bis sie die Entscheidung traf, eine zu Koori sein und verstehen zu wollen, was das eigentlich ist. Und noch später begann sie, Stolz auf ihre Aboriginalität zu empfinden.

Das Buch ist keine Autobiographie über ein Mitglied der Stolen Generations, denn Lorraine McGee-Sippel wurde als Baby zur Adoption freigegeben. Es ist eine Geschichte vor allem über vier Themen, die im Leben der Autorin entscheidend waren: Armut, Lüge, ungenügende Mutterliebe und natürlich Identität. Es ist für Menschen von essenzieller Bedeutung zu wissen, woher sie kommen, welches die Wurzeln der eigenen Denkweise und Werte sind, zu wissen, wer sie sind. Zumindest ist es für die Menschen äußerst wichtig, denen das vorenthalten wird.

Die Autorin schildert die verschiedenen Vorkommnisse in ihrem Leben aus der Perspektive ihres jeweiligen Alters und lässt den Leser damit am sehr anschaulich beschriebenen Denken und Fühlen in unterschiedlichen Lebensstadien teilhaben. Das macht das Buch zu einer lebendigen Lektüre. Es werden die Zweifel und Unsicherheiten beschrieben, die entstehen, wenn Stillschweigen über die Herkunft verlangt wird - lange Jahre durfte nicht öffentlich werden, dass sie adoptiert war -, wenn Geheimnis und Lüge existieren, wo ein Bedürfnis nach Klarheit besteht. Die Beschreibung vor allem ihrer Emotionen eröffnet die Chance, die tiefen Verletzungen, die Zerrissenheit und die Gefühle von Unvollständigkeit überhaupt annähernd verstehen zu können. 
Insgesamt ist das Buch mit sehr viel Empathie geschrieben. Die Zufälle, Überraschungen und verblüffenden, fast unwirklichen Ähnlichkeiten herauszufinden, die sie bei ihrer Suche nach ihren leiblichen Eltern und ihrer großen Familie erlebte, überlasse ich der geneigten Leserin.

Die Autorin hat Gedichte in vielen Anthologien veröffentlicht. Das Manuskript des Buches „Hey Mum, What's a Half-Caste?" kam 2006 und 2007 in die engere Wahl des prestigeträchtigen David Unaipon Award für indigene Autoren, der Teil der Queensland Premier's Literary Awards ist. 2008 erhielt Lorraine McGee-Sippel den Inaugural Yabun Elder Award für ihren Beitrag zu Reconciliation. 2009 gewann sie den Aboriginal and Torres Strait Islander Deadly Award für herausragende Leistungen in der Literatur.

Das Buch ist im Non-Profit-Verlag Magabala in Broome erschienen, in dem nur Aborigines, Torres Strait Islander und Südseeinsulaner publizieren können. Es liegt bereits in der zweiten Auflage vor.

\section{Belonging Where?}

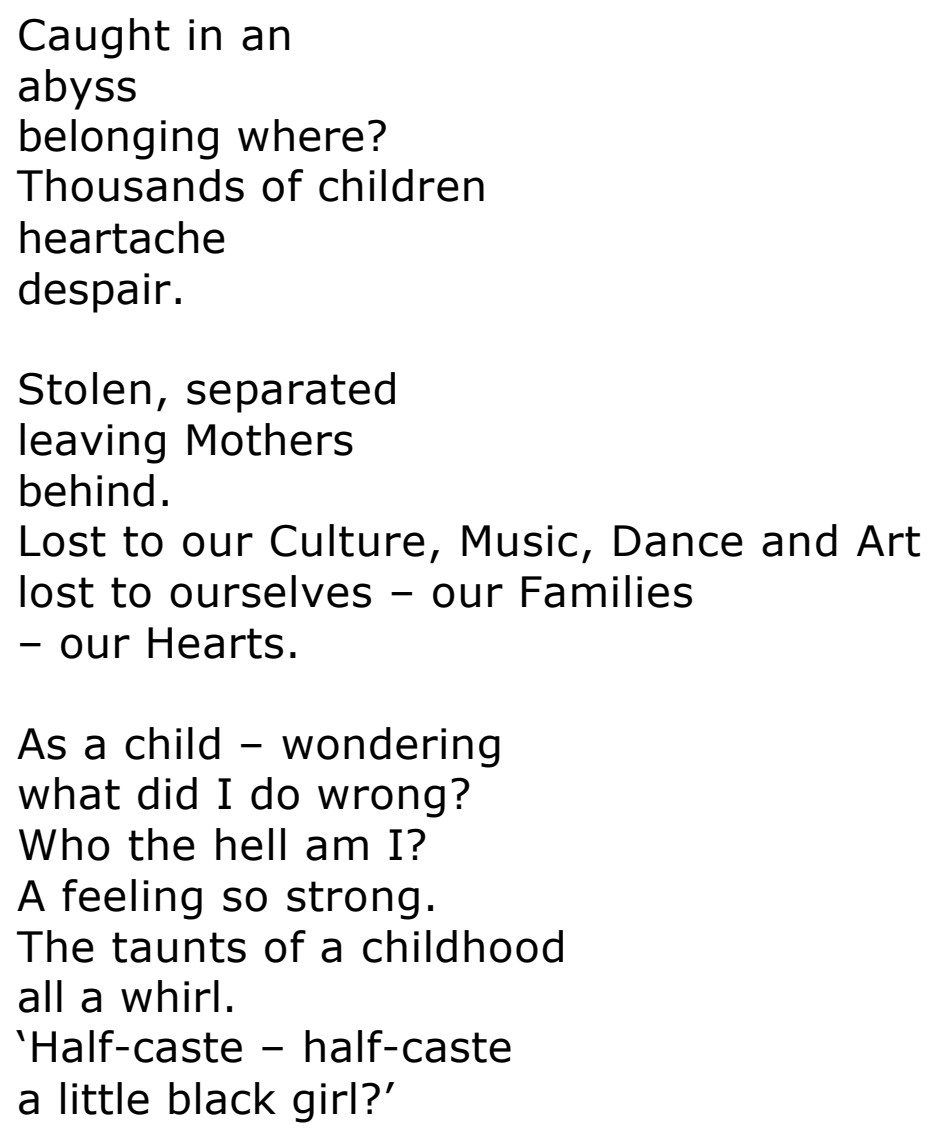


'Italiano?

Greek?

Maori? or what?'

Some of the questions

- asked a lot.

Too black to be white

Too white to be black.

Caught in the middle

belonging - nowhere.

Lorraine McGee-Sippel, 1997

in: Haebich, Anna and Doreen Mellor. Many voices: reflections on experiences of Indigenous child separation, S.69, National Library of Australia, Canberra 2002 
Carl Bridge, Robert Crawford and David Dunstan, Eds. Australians in Britain: The Twentieth-Century Experience. Monash University ePress, 2009. 256 pp. ISBN: 9780980464863. Von Stefanie Land, FU Berlin.

Entgegen der vertrauten Wahrnehmung Australiens als Einwanderungsland widmet sich der Sammelband Australians in Britain der Erschließung des umgekehrten Blickwinkels: $\mathrm{Er}$ untersucht Emigrationsbewegungen aus Australien in das einstige Mutterland Großbritannien. Die sechzehn Beiträge des Bandes gehen dabei auf ein Symposium des Menzies Centre for Australian Studies und des National Centre for Australian Studies der Monash University zurück, welches im Jahr 2005 im Rahmen eines gemeinsamen Forschungsprojektes beider Institutionen, "The Australian Diaspora in Britain since 1901", abgehalten wurde. Die Herausgeber, Carl Bridge (King's College London), Robert Crawford (University of Technology, Sydney) und David Dunstan (Monash University) setzen sich dabei zum Ziel, die bestehende Forschung zu ergänzen, indem sie sich nicht den bereits hinreichend untersuchten Aufenthalten berühmter australischer Intellektueller und Künstler der Baby Boomer-Generation zuwenden (so lautet der Titel der Einleitung treffend "More than just Barry, Clive and Germaine" - ein Verweis auf die "cultural 'gang of four'" (S. 01.1) ${ }^{1}$, Barry Humphries, Clive James, Germaine Greer und Robert Hughes, die in den 1960er Jahren ihre Karrieren in London begannen), sondern vor allem jenen un- oder wenig bekannten Australierinnen und Australiern, die sich nach Großbritannien aufmachten, um ihre Karrieren voranzubringen bzw. überhaupt erst berufliche Möglichkeiten wahrnehmen zu können, die ihnen im Heimatland verschlossen blieben. Ferner widmen sie sich denen, die zeitlich enger begrenzt auf die Insel kamen - ob als Touristen oder als Soldaten während des Ersten Weltkrieges.

Die Herausgeber nehmen keine klare Kategorisierung der

${ }^{1}$ Da es sich um einen auch in elektronischer Form publizierten Band handelt, dessen Kapitel einzeln erworben werden können, ist die Seitennummerierung nicht fortlaufend angelegt, sondern beginnt in jedem Kapitel mit der Seitenzahl 1. Die Kapitelzahl wird durch die ersten beiden Ziffern angegeben: 01.1. steht somit für Kapitel 1, Seite 1. 
verschiedenen Beiträge vor; so scheint die Reihenfolge der Kapitel teils etwas willkürlich gesetzt, vor allem aber erschwert die fehlende Erläuterung des Aufbaus die Leserorientierung. Versucht man sich dennoch an einer vorsichtigen Unterteilung der Beiträge, lassen sich grob die folgenden fünf Bereiche benennen:

1. Demographische Betrachtungen australischer Einwanderungsbewegungen nach Großbritannien,

2. Kulturhistorische Studien zu spezifischen australischen Einwanderungsgruppen (Frauen, Künstler, Soldaten, Journalisten, Studenten, Schriftsteller), die zumeist anhand der Biographien einzelner oder mehrerer Personen Einwanderungsmotive, Lebenswelten und Beziehungen zur britischen Gesellschaft ergründen

3. Die Geschichte des australischen Tourismus in Großbritannien

4. Studien der australischen Presse in London als Spiegel der australischen Diaspora (British Australasian um die Jahrhundertwende sowie Australasian Express, London Australasian Magazine (LAM) und The News and Travel (TNT) von den 70ern bis in die 90er Jahre) sowie

5. Kulturhistorisch angelegte Studien zu australischer Einwanderung bzw. zu australischen Reisenden in bestimmten Zeitperioden (mit einem Fokus auf die 60/70er Jahre sowie die Gegenwart). Die Anordnung der Beiträge gibt diese mögliche Untergliederung jedoch nur teilweise wieder.

Australians in Britain beginnt mit einem Blick auf die Statistik, der eine Reihe kritischer Fragen aufwirft, die in den Fallbeispielen der Folgekapitel wieder aufgegriffen werden. Carl Bridge befasst sich mit der Analyse der Zensus-Daten Englands und Wales' aus dem Jahre 1901 und konstatiert, dass die Zahl der Auswanderer nach Großbritannien, gemessen an der Gesamtbevölkerung des Herkunftslandes, nirgends so hoch sei wie in den Staaten des Empires - und in keinem Land (mit der Ausnahme Neuseelands) höher als in Australien (S. 04.1). Die Einwan-derungsfreudigkeit nach Großbritannien, so Bridge, sei somit ein treffsicherer Indikator für die Zugehörigkeit (und man möchte ergänzen: für das Zugehörigkeitsgefühl) zur "Britischen Welt".

Bridges Artikel weist weiterhin auf eine Definitionsproblematik hin, die in Graeme Hugos (und später in Robert Crawfords) Ausführungen zur gegenwärtigen Einwanderungssituation erneut auftaucht: Die Frage, welche Bevölkerungsgruppen durch die Statistik als 
australische Einwanderer gezählt werden und welche nicht. Indem der Zensus von 1901 nur in Australien Geborene als Australier identifiziert, werden außerhalb Australiens Geborene, die möglicherweise den Großteil ihres Lebens in Australien verbracht haben und sich selbst als Australier verstehen, nicht als australische Einwanderer erfasst (S. 04.2). Die Statistiken, mit denen Hugo arbeitet, unterscheiden teils zwischen in Australien geborenen Einwanderern und "former settlers", also jenen, die außerhalb Australiens geboren wurden, dann zunächst nach Australien und schließlich nach Großbritannien emigrierten (S. 02.2ff). Die "former settlers"-Kategorie umfasst dabei eine hohe Zahl wieder heimkehrender Briten. ${ }^{2}$

Crawford notiert mit Bezug auf aktuelle Zahlen, dass rund ein Viertel aller Australier außerhalb Australiens geboren wurde, sie und ihre Nachkommen damit zur doppelten Staatsbürgerschaft berechtigt sind. Geschätzte 1,5 Millionen Australier verfügen auch über einen britischen Pass (S. 16.2) - diese Personengruppe wird vom britischen Zensus nach wie vor nicht in den Statistiken zur australischen Immigration erfasst. Die Schwierigkeiten bei der demographischen Erfassung von australischer Einwanderung nach Großbritannien machen den hohen Grad der Verflechtung der britischen und australischen Gesellschaften deutlich, die sich einer klaren Kategorisierung von Ein- und Auswanderung sowie von nationalen Identitäten mitunter verschließen.

So stellt sich die von den Herausgebern bereits in der Einleitung aufgeworfene Frage, nämlich ob man überhaupt von einer australischen Diaspora sprechen könne (S. 01.2) - einer Minderheit in der Aufnahmegesellschaft also, die ihre eigentliche Heimat verlassen hat. Die Herausgeber verweisen hier auf die Arbeiten des Soziologen Robert Cohen und schließen, dass trotz des

${ }^{2}$ Leider fehlt in Hugos Text dabei die Angabe darüber, welcher Mindestzeitraum für einen Aufenthalt in Australien für jene Briten angelegt wird, um sie als "Auswanderer" nach Großbritannien in der Statistik erscheinen zu lassen bzw. ob in späteren Jahren (mit der Abschaffung des "Commonwealth Citizen"-Status durch den British Nationality Act von 1981), eine Annahme der australischen Staatsbürgerschaft vorausgesetzt wird (vgl. Abbildung 2.5 S. 02.6). 
Verständnisses Großbritanniens als "home", welches bis zum Zweiten Weltkrieg bzw. der Hinwendung Großbritanniens zur europäischen Gemeinschaft und der damit einhergehenden Abkehr vom alten Empiregedanken dominierte, der Terminus der australischen Diaspora treffend sei (Ebd.). Mit Bezug auf Cohen nennen sie dabei als Gründe das kollektive Gedächtnis, das jene australischen Einwanderer auch in Übersee beibehielten und nährten, sowie das dem Großteil der Einwanderer gemeinsame Motiv, Australien aus Arbeitsmarkt- bzw. Karrieregründen verlassen zu haben.

Die spannende Frage nach der Identitätskonstruktion und dem Zugehörigkeitsgefühl zur britischen Nation wird anschließend von zahlreichen Autoren aufgegriffen. Wenngleich ein separater Artikel zur tiefergehenden, umfassenderen Diskussion der Frage nach australischer, britischer und imperialer Identität im Kontext der Einwanderungsgeschichte nach Großbritannien gewinnbringend und wünschenswert gewesen wäre, so zeigen die einzelnen Fallstudien im Gesamtbild doch die Komplexität der Thematik auf. So wird etwa verschiedentlich die "Magie der Ankunft" thematisiert. Hierin kommen die durch Schulunterricht, Politik, und Kunst lange genährte und fest verankerte australische Betrachtung Großbritanniens, und insbesondere Londons, als Zentrum des Empires und die natürliche Vertrautheit mit seiner Geschichte und Geographie zum Ausdruck. Die Ankunft im Zentrum konnte dabei eine Affirmation der imperialen und/oder britischen Identität mit sich bringen, führte aber auch zu einem Bewusstwerden über die eigene australische, und damit "koloniale" Herkunft. Die Wahrnehmung von Australiern durch die britische Gesellschaft, insbesondere der Upper Class, deutet im Gegenzug auf eine Tendenz zur Geringschätzung hin.

Diese und andere Reaktionen der Aufnahmegesellschaft konnten dabei Minderwertigkeitsgefühle ebenso hervorrufen wie die Betonung der eigenen Australianness. Für einige wenige wurde die Vermarktung der australischen Identität bzw. ihrer Karikierung zum Karrierebeschleuniger - so für die "cultural 'gang of four"' (S. 01.1, S. 14.1). Weniger bekannte Persönlichkeiten hingegen fanden sich allenfalls zufällig und ungewollt in einer Vermarktungssituation. So wird der Fall einer Journalistin geschildert, die im Auftrag einer Agentur vermeintlich authentische australische Geschichten 
verfasste: Selbst in Sydney aufgewachsen schrieb sie über das ländliche Northern Territory und Känguru-Jagden mit Aborigines (S. 08.11). Die Mehrheit der australischen Schriftsteller und Journalisten in England jedoch, das legt John Arnolds Artikel überzeugend dar, publizierte kaum zu australischen Themen und verstand sich nicht als explizit australische Schriftsteller bzw. Journalisten (S. 10.13).

Eine weitere zentrale Erkenntnis, welche durch die Einwanderungsstatistiken zu Tage gefördert wird, ist die Charakterisierung des durchschnittlichen australischen Einwanderers des 20. und 21 . Jahrhunderts als weiblich und Mitte zwanzig. Die Tatsache, dass die Zahl der nach Großbritannien einreisenden Australierinnen die der Australier übersteigt, bleibt dabei seit Beginn des 20. Jahrhunderts konstant. Hugo schließt daraus, dass insbesondere für die Einwanderung von Frauen dem "Initiationsritus", der Tradition eines Aufenthaltes in Großbritannien als Teil des Erwachsenwerdens, eine zentrale Rolle zukommt. Der rite of passage, der ursprünglich vor allem für die Elite, Intellektuelle und Künstler obligat war, habe sich im Laufe des 20. Jahrhunderts auf andere gesellschaftliche Gruppen ausgeweitet (S. 02.1, 02.8, 02.11). Angela Woollacott ergänzt diese Erklärung, indem sie darlegt, dass im Gegensatz zu australischen Männern die Steigerung der Möglichkeiten durch eine Auswanderung für jene Frauen noch um ein vielfaches größer war, da sie hierdurch der Diskriminierung aufgrund ihres Geschlechtes ausweichen konnten - insbesondere auch den Rollenerwartungen der eigenen Familie (S. 03.1). Ein Aufenthalt in London bzw. Großbritannien eröffnete durch seine Akzeptanz als kulturelles Ritual die Möglichkeit, als Frau berufliche Ambitionen auszuleben und weiter in die öffentliche Sphäre vorzudringen, als dies in Australien möglich gewesen wäre, ohne hierfür gesellschaftliche Sanktionen zu erfahren (vgl. S. 03.3f). Dies demonstriert auch Bridget Griffen-Foleys Beitrag, der die Auswanderung australischer Journalisten untersucht und feststellt, dass Auswanderungsmotive von Journalistinnen nicht nur die Hoffnung auf einen Karrieredurchbruch im "Zentrum des Empire" umfassten, sondern durchaus auch Flucht vor oder zumindest Verzögerung von Heirat (S. 08.3). So war für viele Australierinnen nicht der rite of passage selbst Motiv, sondern vor allem willkommene Gelegenheit zur Emanzipation. 
Abschließend soll auf drei besonders bereichernde und pointierte Artikel eingegangen werden, welche in die Themenbereiche Australian Community Press sowie Studien zum Tourismus bzw. zur Einwanderung in bestimmten Zeitperioden fallen.

Simon Sleights Artikel zur Geschichte der Boulevardzeitung British Australasian der Jahre 1884-1924 zeigt auf, dass die Zeitschrift erfolgreich auf eine transnationale Identität von "Briten" in der südlichen Hemisphäre abzielt, ohne dass dabei ein Widerspruch zwischen der Identifikation der Leser als Briten (oder zumindest: als britisch) und der Affirmation der nationalen Identität als Australier oder Neuseeländer bestehen würde (S. 07.1, 07.9).

Richard White kommt in "Australian Tourists in Britain, 1900-2000" noch einmal auf die Frage nach Großbritannien als Heimat zurück und fragt: "How can someone be travelling when they have just arrived 'home'?" (S 11.2) Gemäß der Definition eines Reisenden als "individual adventurer who quests for the unexpected" (Ebd.), folgt die Antwort: "They can't". Australier können sich in die britische Gesellschaft einfügen (oder dies zumindest versuchen), als Touristen kommen, oder sich in Großbritannien auf eine Reise nach sich selbst machen, so White - nie aber würden sie etwas Neues entdecken können (S. 11.3).

Mit Graeme Davisons Beitrag wendet sich der Band erstmals jenen unbekannten Australiern zu, die als Fachkräfte nach Großbritannien kamen - nicht als Künstler, Schriftsteller oder Journalisten, nicht als Teil einer sozialen Elite und auch nicht in den Sonderkategorien der Soldaten und Touristen. Seit den 60ern bestand ein Großteil der australischen Diaspora in Großbritannien aus Fachpersonal, insbesondere Kranken-schwestern und Lehrerinnen, die temporär oder langfristig in Großbritannien Arbeit fanden. Als repräsentative Beispiele für diese Gruppe zeichnet Davison die Erfahrungen zweier australischer Lehrerinnen nach, von denen eine nur auf Zeit, die andere dauerhaft in England bleibt. Die Berichte der temporär emigrierten Lehrerin verdeutlichen abermals die Faszination und die Ambivalenz der Vertrautheit Londons und Großbritanniens, die Affirmation der britischen Identität bei der Ankunft und das Gefühl, in Großbritannien am Ort des Originalen, Echten angekommen zu 
sein. Ihr Lebenslauf macht auch deutlich, wie Großbritannien für viele Australier als Ausgangspunkt für Reisen nach Kontinentaleuropa wurde, wie der Aufenthalt im "Ausland" Großbritannien zur Reflexion der eigenen Werte und der Lebenssituation in Australien führt (vgl. S. 14.5) - und somit zum tatsächlichen rite of passage als Schritt des Erwachsenwerdens. Die dauerhafte Auswanderin hingegen zeigt einerseits eine teils komische, teils sentimentale Affirmation der eigenen Identität als Australierin, andererseits steht ihre Transnationalität beispielhaft für die vieler Einwanderer: Zweimal kehrt sie länger mit ihrem englischen Gatten nach Australien zurück, um dann wieder nach Großbritannien aufzubrechen. Schließlich zieht sie in ein Dorf, das nur wenige Minuten vom Herkunftsort ihrer nach Australien ausgewanderten Vorfahren entfernt liegt. So schließt sich mit diesem Kapitel auch thematisch der Kreis - es macht einmal mehr deutlich, wie eng australische und britische Gesellschaft verflochten sind.

Australians in Britain gewährt wertvolle Einblicke in eine noch wenig erforschte Perspektive der britisch-australischen Beziehungen. Der Band ist dabei insbesondere für Historiker und Kulturwissenschaftler sowie, durch hervorragende Beiträge von Richard White, Graeme Davison und Mathew Trinca, für die Tourismusforschung interessant. Wenngleich am Band ein wenig enttäuscht, dass einige der Artikel sich wieder den bereits hinreichend erforschten Einwanderungsgruppen bzw. Persön-lichkeiten zuwenden (so etwa Simon Pierse in "Australian Artists in London: The Early 1960s") oder sich allzu sehr in anekdotenhaften Erzählungen und Details verlieren, (so John Rickards bei der Spurensuche zum Haus von Tom Roberts) so fördert er doch zahlreiche neue Erkenntnisse zu Tage und eröffnet eine Ausweitung der Forschung auf die vielen "unbekannten" Immigranten. Im Gegensatz zu Intellektuellen und Künstlern fanden Letztere bisher wenig Beachtung, obgleich sie die Mehrheit der australischen Einwanderer nach Großbritannien darstellen. Ein Beispiel sind die zahlreichen australischen Krankenschwestern, die im vorliegenden Band durch ein Bild auf dem Titelblatt gewürdigt werden - deren Situation jedoch leider noch durch keinen der Artikel näher beleuchtet wird. 
J. Seipel: Film und Multikulturalismus. Repräsentation von Gender und Ethnizität im australischen Kino. Bielefeld: transkript Verlag, 2009. 288 S., brosch., $€$ 29,80.-; ISBN 978-38376-1174-8. Rezensiert von Arno Rußegger, Universität Klagenfurt

as vorliegende Buch setzt an einem Desiderat filmwissenschaftlicher Forschung an und konstatiert zunächst, dass es "im deutschsprachigen Raum so gut wie keine intensiven Auseinandersetzungen mit Filmen aus Australien" gebe (S. 10). Nun, die Verfasserin schickt sich nicht bloß an "diese Lücke zu füllen" (ebd.), sondern legt geradezu ein Grundlagenwerk vor, das für alle, die sich für die bemerkenswerten Entwicklungen und Veränderungen innerhalb des Weltkinos der letzten Jahrzehnte interessieren, eine wahre Fundgrube an grundsätzlichen kulturtheoretischen Erörterungen in Verbindung mit stupenden Kenntnissen über Details filmästhetischer Darstellungsmöglichkeiten bietet. Seipels Ausführungen gehen zwar von den speziellen Bedingungen der australischen Filmproduktion Mitte der 1990er Jahre aus, eröffnen aber wegen der in jeder Phase der Argumentation überaus souveränen Handhabung sprachlicher Differenzierungen eine Sicht der Dinge, die weit über die Untersuchung und Kommentierung von drei ausgewählten Filmbeispielen ( $A$ Fistful of Flies, 1996; Floating Life, 1996; The Sound of One Hand Clapping, 1997) hinausreicht.

Besonderes Augenmerk legt die Verfasserin auf die Verwendung der für sie zentralen Begriffe wie "Nation", "Ethnizität”, "Geschlecht”, Multikulturalität", "Multikulturalismus" oder „Authentizität", wobei sie sich auch immer wieder vergewissert (vgl. S. 11 und 13), wie sie selbst mit bestimmten Ausdrücken und diskursiven Prägungen umgeht, um schon die geringste Gefahr von blinden Flecken im sensiblen Gefüge ideologischer, politisierter, weiblicher und männlicher Identitätskonzepte zu bannen. Außerdem verfolgt sie - unter Berücksichtigung einer Fülle von einschlägiger Sekundärliteratur, die vor allem aus den Bereichen der Cultural Studies, der Gender bzw. Queer Studies und der Filmanalyse stammt und nicht nur im 
Haupttext, sondern in zum Teil sehr ausführlichen Fußnoten referiert und reflektiert wird - einen klaren inneren Aufbau der Arbeit. Der Bogen wird dabei von der "Konstruktion nationaler und ethnisierter Gemeinschaften" über einen pointierten Abriss der gesamten australischen Filmgeschichte bis hin zu den konkreten Formen der „Inszenierungen von Migration und Multikulturalität" bzw. narrativen Mustern im Film gespannt, die sich im Laufe der Zeit in produktiver Auseinandersetzung mit älteren, bereits vorhandenen literarischen und anderen medialen Repräsentationen von Geschichten migrantischen Inhalts (im weitesten Sinn) herausgebildet haben.

Zur Illustration der Fähigkeit, komplexe Sachverhalte in einem Stil abzuhandeln, in dem gleichzeitig sowohl ein hohes Abstraktionsniveau berücksichtigt wird, als auch das Bedürfnis der Leserinnen und Leser nach Anschaulichkeit, sei auf Seipels Ausführungen zu "Montage" (S. 144ff.) hingewiesen. Dort gelingt es nämlich vorzüglich, einerseits formale und inhaltliche Elemente herauszustellen, die allen drei Filmen gemeinsam sind, und andererseits gerade durch diesen Vergleich die jeweilige Eigenart der Filme nachvollziehbar zu machen. Ähnliches wie für die Bildebene trifft übrigens natürlich auch auf die Analyse der Tonebene und, in der Folge, die umfassenderen dramaturgischen Dimensionen der Erzählungen als solche zu, so dass man schließlich am Ende der Lektüre, nach einem das Wesentliche rekapitulierenden Abschnitt (S. 253ff.), einmal mehr erstaunt ist über die Vielfalt, in der man informiert, instruiert und zum eigenen Nachdenken inspiriert worden ist. Das ist, neben der ohne Zweifel unter Beweis gestellten Gelehrtheit der Verfasserin, vielleicht das eigentliche Hauptverdienst dieses Buches: Jeder allgemeine Sprach-gebrauch, wie er sich gesellschaftlich allenthalben etabliert haben mag und in der Arbeit spiegelt, wird stets kritisch durchleuchtet, was nicht zuletzt zur Folge hat, dass man sich mitunter plötzlich selber in Frage gestellt und herausgefordert sieht, seine Reden über etwaige ethnische und geschlechtsbezogene Zuordnungen in Zukunft noch sorgfältiger zu führen. 
The Literature of Australia: An Anthology. General Editor: Nicholas Jose. Foreword by Thomas Keneally. New York and London: W.W. Norton \& Company. 1464 Seiten. Rezensiert von Horst Prießnitz, Wuppertal

B ereits von den unterschiedlichen Titeln des inhaltlich gleichen, in Australien vom Verlag Allen \& Unwin (Sydney) als Macquarie PEN Anthology of Australian Literature, im Rest der Welt vom Verlag W.W. Norton (New York) als The Literature of Australia: An Anthology vertriebenen, fast 1.500 -seitigen und $1,8 \mathrm{~kg}$ schweren Kompendiums gehen zwei verschiedene, den Blick auf ein und dasselbe Phänomen betreffende Botschaften aus. Die eine ist, dass das von den Schriftstellern des 5 . Kontinents verfasste Schrifttum in New York weniger als Ausdruck einer anglophonen Nationalliteratur, sondern als Literatur mit transnationaler Bedeutung wahrgenommen wird, die lediglich in einem bestimmten Teil einer globalen Welt entstanden ist; die andere ist, dass diese Einschätzung in Sydney noch nicht uneingeschränkt geteilt wird. Diese hermeneutische Differenz spiegelt sich auch in Vorankündigungen bzw. Reaktionen auf die Publikation des Bandes. ${ }^{1}$ Da das Herausgebergremium um Nicholas Jose in Mary Cunnane, einer erfahrenen Lektorin des New Yorker Verlagshauses, die Initiatorin und Begleiterin des Projekts reklamiert, ${ }^{2}$ wird sich The Literature of Australia an den Anthologien der englischen und amerikanischen Literatur aus dem Hause W.W. Norton messen lassen müssen.

Anthologien, so haben es die weltweit verwendeten NAEL und NAAL über viele Jahrzehnte bewiesen, erfüllen trotz ihrer genrebedingten Beschränkungen eine wichtige Funktion als Führer durch die Komplexität und Polyphonie einer literarischen Kultur, wenn sie zur vertieften Beschäftigung mit den bedeutendsten Prosa-, Vers- und Bühnenautoren im Kontext der epochengeschichtlichen Traditionen

\footnotetext{
${ }^{1}$ Vgl. z.B. Nicholas Birns, "Macquarie Anthology to have a global reach". http://www. crikey.com.au/2009/11/04/; Nicholas Jose, "A Shelf of Our Own: Creative Writing and Australian Literature". ABR Nr. 276 (November 2005): 25-29

2 Vgl. Thomas Keneally, "Forword". The Literature of Australia, XXVIII-XXXI, XXX; Jose,

"A Shelf of Our Own", 29
} 
und Gattungen anregen, die Texte möglichst vollständig und zuverlässig wiedergeben, Einleitungen, Erklärungen, Kommentare und bibliographische Referenzen so informativ gestalten, dass der Leser den Band ohne Hilfsmittel benutzen kann, trotz eines stringenten Gesamtkonzepts Freiräume zu individuellen Akzentuierungen bei der Vermittlung einer Epoche oder Gattung belassen, für Revisionen angesichts sich verändernder Kanones offen bleiben, trotzdem über einen langen Zeitraum hinweg den Status eines konsensfähigen Standardwerks bewahren - und dies alles in einem von Umfang und Gewicht her handlichen Format. Darüber hinaus sollten die Textarrangements thematische Schwerpunktsetzungen und Vernetzungen gestatten, historische Entwicklungen sichtbar machen, den Respons von Autoren auf wichtige politische, soziale und geistige Strömungen sowie ihren Beitrag zu deren Genese illustrieren, den Vergleich und die Neuinterpretation wiederkehrender Themen und Motive ermöglichen, die Entstehung und Modifikation von Genres und Formen beleuchten, die mythenbildende und -skeptische Leistung literarischer und anderer Texte in den Blick rücken sowie einen weiten Literaturbegriff zugrunde legen. Dieser Katalog von Zielsetzungen ist nicht Resultat praxisferner Idealvorstellungen, sondern Ergebnis einer Durchsicht der Vorworte zu NAEL und NAAL sowie den entsprechenden Guides for Instructors. ${ }^{3}$

Ein (zugegebenermaßen stichprobenhafter) Vergleich der australischen Anthologie mit ihren englischen und amerikanischen Vorläufern fällt außerordentlich ernüchternd aus. Man muss dem Herausgeberteam zwar attestieren, dass es trotz einer eng ausgelegten Australianness ein weites Literaturverständnis anwendet, so dass neben den klassischen literarischen Formen auch Songs, Sträflingsberichte, Petitionen, Tagebücher, Briefe, Autobiographien und Aufzeichnungen von Expeditionsteilnehmern aufgenommen wurden. Ob allerdings den aboriginalen Stimmen durch den Wiederabdruck von fast $98 \%$ aller Texte aus der von

\footnotetext{
${ }^{3}$ Vgl. M.M. Abrams, "Preface to the Sixth Edition". NAEL (1993): xxx-xxxv; Alfred David, "Preface: A Brief Guide to the Guide". Teaching with The Norton Anthology of English Literature. Sixth Edition. New York and London: W.W. Norton, 1995:xi-xiii; Anon., "Preface of the Fourth Edition". NAAL (1994): xxvii-xxx; Marjorie Pryse, "Author's Introduction". Teaching with The Norton Anthology of American Literature. New York and London: W.W. Norton, 1994: 1-8.
} 
$\mathbf{1 2 8}$ IS eite Horst Prießnitz

Anita Heiss und Peter Minter besorgten Anthology of Australian Aboriginal Literature (2008) so breiter Raum gegeben werden musste, wenn literarische Qualität ein wichtiges Auswahlkriterium bilden sollte, ${ }^{4}$ darf bei allem Wohlwollen für eine politisch und kulturell lange marginalisierte Bevölkerungsgruppe zumindest gefragt werden. ${ }^{5}$ Bei den politischen Reden sind Robert Menzies, Gough Whitlam und Paul Keating vertreten, - warum nicht auch Bob Hawke? Eine Karte, die die Geschichte des Kontinents bis zum Commonwealth of Australia (mit den verschiedenen Bundesstaaten) veranschaulicht, eine Liste aller Gouverneure und Premierminister (mit Parteizugehörigkeit) seit 1901 sowie eine Chronik der wichtigsten politischen, sozial- und kulturgeschichtlichen Ereignisse, auf die in Texten Bezug genommen wird, wären hilfreich gewesen. Nicht jeder Benutzer in Übersee ist schließlich mit der Geographie und Geschichte des 5. Kontinents vertraut.

Was den Wert des Kompendiums erheblich schmälert, ist neben einer Reihe von Unstimmigkeiten die problematische Gesamtkonzeption. Zwar verfügt der Band über Angaben zu den Veröffentlichungsdaten der aufgenommenen Texte, Quellenverweise auf die maßgeblichen Ausgaben bzw. Manuskripte, Kurzeinführungen zu den Autoren mitsamt (spärlichen) Hintergrundinformationen sowie ein Glossar, aber das Zusammenspiel der Informationen funktioniert nicht immer. Wer sich z. B. über einen bestimmten Autor kundig machen möchte, muss sich durch das chronologisch angeordnete Inhaltsverzeichnis arbeiten, um ihn aufzuspüren. Ein zusätzliches alphabetisches Autorenverzeichnis hätte dem Leser viel Zeit und Mühe erspart. - Peter Careys Roman heißt einmal (Seite 1043) My Illegal Self (inkorrekt), ein anderes Mal (Seite 1415) His Illegal Self (korrekt). Unerfindlich ist, weshalb (Seite 1415) nur vier Romane Careys aufgeführt werden. Auch andere Eintragungen weisen Unstimmigkeiten auf, die das Vertrauen in die Zuverlässigkeit der Angaben nicht eben bestärken. - Unter der Überschrift Selected Reading treffen auf Seite 1414 oben zwei typo-

\footnotetext{
${ }^{4} \mathrm{Vgl.} \mathrm{Nicholas} \mathrm{Jose,} \mathrm{"General} \mathrm{Introduction",} \mathrm{The} \mathrm{Literature} \mathrm{of} \mathrm{Australia,} \mathrm{1-6,} 2$.

${ }^{5}$ Vgl. dazu: Peter Craven, "Obscuring the Heritage: Regrettable omissions in the new national anthology". ABR Nr. 314 (September 2009): 7-8; sowie die Reaktionen in Form von Leserbriefen von Nicholas Jose, Ian Britain und Peter Craven: ABR Nr. 315 (October 2009): 4-5; vgl. auch Fiona Gruber, "Dream time". TLS (February 5, 2010): 12-13; Peter Pierce, "Macquarie PEN Anthology of Australian Literature".
} 
graphisch und wohl auch inhaltlich unterschiedliche Titellisten kommentarlos aufeinander. Fehlt hier eine Zwischenüberschrift? Welche jeweils verschiedenen Informationen wollten die Herausgeber dem Benutzer mit den beide Male alphabetisch arrangierten Literaturangaben - von Michael Ackland bis Judith Wright (1409 - 1414) sowie von Mena Abdullah bis Fay Zwicky (1414 - 1427) geben?

Was den Band zu einem Ärgernis macht, ist die chronologische Anordnung der Einträge, denn sie setzt die literaturgeschichtlichen Kenntnisse voraus, zu deren Erwerb er wohl in erster Linie vorgesehen sein dürfte. Fairerweise muss gesagt werden, dass den Kompilatoren der australischen Sammlung NAEL und NAAL auf zwei Gebieten, wenn überhaupt, nur bedingt als Vorbild dienen konnten: bei der periodischen und kanonischen Strukturierung des Textcorpus.

Was die Periodisierung betrifft, experimentiert die literarische Historiographie Australiens seit der (immer noch nicht gänzlichen) Verabschiedung der Sequenzierung in eine 'koloniale', 'nationale' sowie 'internationale / moderne / reife' Phase mit verschiedenen, vorrangig rein temporalen Segmentierungen, da sie sich noch nicht auf ein allgemein akzeptables Narrativ sowie Periodenschema mit Epochenbezeichnungen und -grenzen verständigen konnte. Die daraus resultierenden Probleme durch eine Flucht in die Chronologie umgehen zu wollen, ist jedoch keine Lösung, denn sie versperrt den Blick auf historische, inhaltliche und formale Zusammenhänge und Entwicklungen. Die den Einträgen vorangestellten Kurzessays verfehlen ihre Orientierungsfunktion, da sie auf einem konfusen Strukturprinzip basieren, zudem mit einer problematischen Rubrizierung operieren und die nur oberflächliche Verortung von Autoren und Werken erlauben. Auf den Artikel zur Aboriginal Literature (von den Anfängen bis zur Gegenwart) schließen sich zwei Beiträge zur Literature to 1900 und 1900 to 1950, gefolgt von zwei Skizzen zu Fiction and Drama from 1950 sowie Poetry and Nonfiction from 1950. Haben Aborigines nicht auch Dramen, Gedichte und Romane geschrieben? Gibt es vor 1950 kein Drama und keine Lyrik? Seit wann zählen Romane, Dramen und Gedichte nicht zur 
Literatur? Was haben nichtfiktionale Prosa und die sprachlich von ihr am weitesten entfernte Lyrik gemeinsam, dass man sie in den gleichen Kategorientopf werfen dürfte? Und wie begründen sich die Zäsuren 1900 und 1950, die ja ein rudimentäres dreiteiliges Epochengerüst, - vor 1900, 1900-1950, nach 1950 -, konstituieren, und weshalb kommt es bei dem Arrangement der Texte nicht zur Geltung?

Auch die Kanonbildung stellte für den Herausgeber und sein Kollegium eine besondere Herausforderung dar. Anders als in literarischen Kulturen mit einem etablierten Kernbestand von Autoren und Texten, der nur von Zeit zu Zeit modernisiert werden muss, haben Jüngere, wie z.B. diejenige Australiens, einen Kanon erst gegen zahlreiche Widerstände und zentrifugale Tendenzen durchsetzen können. ${ }^{6}$ So beanspruchen in hochgradig pluralistischen und multikulturellen Gesellschaften scheinbar jedes Milieu und jede Splittergruppe jeweils eigene Kanones, begründet sich Kanonzugehörigkeit nicht länger allein durch literarische Qualität, weil immer auch soziale Bedürfnisse wie z.B. die leidige (nationale) Kulturidentität befriedigt werden wollen. Kanones sind selbst in Kulturen mit einer langen Klassikertradition keine geschlossenen, sondern sich immer wieder neu formierende Systeme. Dennoch hätte sich der Spagat zwischen dynamischer Flexibilität und klassischer Stabilität anders leisten lassen als durch die Schaffung eines neuen Problems, das sich auf die Frage bringen lässt, wie ein sehr breit gefächertes Ensemble von Zielvorstellungen mit kanonischem Anspruch mit einem chronologischen Arrangement von Texten und Autoren einher gehen kann. Nach dem Willen des Herausgebers soll die Anthologie als ein Mosaik individueller Äußerungen gleichzeitig ein vielfarbiges und charakteristisches Gesamtbild einer lebendigen, faszinierenden und unverwechselbaren Literatur zeichnen, ihre Gattungs- und Stilvielfalt sowie ihren Wandel in den verschiedenen Entwicklungsphasen dokumentieren, dem zeitgenössischen Leser die qualitative Signifikanz und Repräsentativität der Texte nahe bringen, unterschiedliche Modi

\footnotetext{
${ }^{6} \mathrm{Vgl}$. dazu Sophie Cunningham, "The black and white of the Australian literary canon". http://www.crickey.com.au/2009/09/04; Nicholas Jose, "Australian literature and the missing body". ABR Nr. 313 (July-August 2009): 22-24.
} 
literarischer Kreativität beleuchten, Haupt- und Nebenströmungen des literarischen Schaffens durch das Nebeneinander von Bekanntem und weniger Bekanntem vorstellen, Affinitäten, Gegensätze, Echos, Verbindungs- und Entwicklungslinien aufzeigen und die Betonung des 'Australischen' sowie des explizit 'Unaustralischen' exemplifizieren. Die charakteristischen Merkmale der Literatur Australiens erblickt Jose in folgendem Profil:

Features of Australian writing include the contending identifications of class ..., race, gender, region ..., background, belonging, politics - and sheer good fortune or the lack of it. It can be a literature of impersonation and reinvention, whether comic or tragic, of plainness or exaggeration, of fate and the roll of the dice; a literature of struggle, survival and making it (up). It can be brooding or sparkling, frequently irreverent, occasionally solemn, cheeky, gentle, outlandish, or impassioned. Sometimes, combining terms that are unsettled and open to redefinition, Australian literature has a do-ityourself quality - creating new from old, folding in the non-literary, turning the literary outward to social agency. This may explain the open-endedness and formal indeterminacy of many of the most intriguing works. ${ }^{7}$

Wie sich der Benutzer des Bandes alle diese Eigenschaften allein durch die Lektüre der Texte erschließen (und ggf. andern vermitteln) soll, ist schleierhaft.

Thomas Keneally, der mit seinem Vorwort das Vorhaben nobilitiert, muss geschwant haben, dass die Einleitung mehr Erwartungen weckt als der Band erfüllt. $\mathrm{Er}$ versucht nämlich, konkrete thematische Bezüge zwischen Texten und Textgruppen zu knüpfen. In dem Kontrast zwischen dem Alter des Kontinents und seiner aboriginalen Kultur sowie der relativen Jugend der britischen und europäischen Zuwandererkultur, den Implikationen des Antipodenmythos, der seit der Antike die Perzeption der terra australis beeinflusst hat, in der Auseinandersetzung mit dem Modell Amerika, in der geokulturellen Sonderposition zwischen Europa und Asien, in dem Aufeinandertreffen verschiedener Ethnien sieht Keneally struktur-, profil- und kanonbildende Aspekte. Ihnen ließen sich weitere hinzufügen, so z.B. das auffällige Interesse an ökologischen Fragestellungen, an poetologischen Reflexionen, die utopischen

\footnotetext{
7 Jose, "General Introduction", 5.
} 
132 ISeite Horst Prießnitz

Träume, die literarische Reiselust oder die Beschäftigung mit den Konsequenzen des Transhumanismus. Man könnte diese nachweislichen Präferenzen mit dem von Niklas Luhmann in die Diskussion eingeführten Begriff der Anschlussfähigkeit als kanonrelevant rechtfertigen. Gemeint ist damit der Mechanismus, dass ein Text dann kanonischen Status erwirbt, wenn er sich ästhetisch oder anderweitig bereits kanonisierten anschließt, bzw. sich, wie T.S. Eliot gesagt haben würde, produktiv in eine Tradition einschreibt. Viele dieser Themen und Texte sind ja bereits anderswo traditions- und somit kanonprägend geworden, so etwa in The Oxford Anthology of Australian Literature (1985) von Leonie Kramer und Adrian Mitchell, der von Ken Goodwin und Alan Lawson betreuten und leider vergriffenen The Macmillan Anthology of Australian Literature (1990), dem von Nicholas Birns und Rebecca McNeer edierten A Companion to Australian Literature since 1900 (2007; rezensiert in der ZfA 23, S. 87-95), vor allem aber in der zeitgleich mit der vorliegenden Anthologie entstandenen, von Peter Pierce herausgegebenen The Cambridge History of Australian Literature (2009). Sie wird in dieser Nummer besprochen s.S. 100 108. Eine nach traditionsbildenden thematischen Gesichtspunkten organisierte Anthologie wäre eine wesentlich benutzerfreundlichere Alternative zu dem chronologischen Arrangement gewesen.

Die Anthologie richtet sich dezidiert an Studierende tertiärer Institutionen; der (australische) Verlag bewirbt sie als "a must for every Australian home".8 Die auf NAEL und NAAL bezogenen Teaching Guides bieten dem akademischen Lehrer zusätzlich zu den strukturellen Vorgaben der Epochengliederung mehrere Modelle mit Variationen sowie Lektürevorschlägen für die praktische Vermittlung an. Die australischen Kompilatoren vertrauen offenbar darauf, dass Kursleiter die in der "General Introduction" aufgelisteten Zielsetzungen je nach Bedarf extrapolieren, selbst mit den Autoren und Texten korrelieren und auf dieser Basis ihre eigenen synchron oder diachron organisierten Lehrmodule komponieren. Dass für das australische Pendant ein allerdings für Unter-, Mittel- und Oberstufe weiterführender Schulen konzipierter Teaching Guide existiert, erfährt man nicht aus der Anthologie selbst, sondern eher beiläufig

\footnotetext{
${ }^{8}$ Der volle Wortlaut auf dem Flyer lautet: A celebration of a rich living literature, a must for every Australian home. Sie wird in dieser Nummer besprochen, s.S. $98-108$
} 
aus dem Hinweis in einer Ankündigung des Herausgebers. ${ }^{9}$ Verantwortlich für den nur im Internet zugänglichen Guide ${ }^{10}$ und die dazugehörigen DVD-Materialien zeichnen zwei akademische Lehrer an der Macquarie University, Donna Gibbs und Kerry-Ann O'Sullivan. Die Autorinnen vertreten die Überzeugung, dass die universitäre Lehre von den curricularen Einheiten profitieren könne, da sie sich leicht an das höhere Niveau adaptieren ließen. Außerdem rechtfertigen sie ihr Projekt mit der etwas vollmundigen Behauptung, dass "[a]s one of the great literatures of the world, Australian literature has its place in the educational curricula of countries around the globe". ${ }^{11}$ Die nach Schulstufen ausdifferenzierten und mit Lektüreempfehlungen versehenen thematischen units umfassen: (1) Texte aus einem ähnlichen historischen Kontext, (2) solche mit Fokus auf einem bestimmten Raum, (3) andere, die thematische Binnenverbindungen (z.B. Krieg, Musik, Einsamkeit, Kindheit, Identitätsfindung, Leben in der Stadt oder im Busch) aufweisen, (4) Texte, die sich mit der Familie oder anderen Beziehungen befassen, (5) Texte gleichen oder unterschiedlichen Genres, die man als Adaptationen aus anderen Gattungen klassifizieren könnte, (6) Texte mit innovativem oder experimentellem Anspruch, (7) solche, die von Autoren mit einer gemeinsamen Erfahrung (z.B. Aboriginalität, Immigration, Weiblichkeit/Männlichkeit) stammen, (8) Texte, die einen bestimmten Standpunkt hinterfragen bzw. zu ihm eine dezidiert abweichende Position einnehmen, (9) Texte, die die gesamte Bandbreite des Komischen abdecken, also Witze, Satiren, Parodien etc. und (10) dialogische Texte, die Affinitäten, Kontraste oder Echos zu/aus andern markieren. Man kann über das zugrunde liegende Konzept streiten, nicht jedoch darüber, dass dieser Guide das Bedürfnis mindestens einer Rezipientengruppe nach zusätzlichen Ordnungskategorien in dem chronologischen Textarrangement der Anthologie demonstriert. The great Australian literature quiz, ${ }^{12}$ das auf irgendeine Weise mit dem Guide verbunden ist, konfrontiert Schüler z.B. mit folgenden Fragen:

\footnotetext{
${ }^{9} \mathrm{Vgl}$. Jose, "Australian literature and the missing body", 23.

${ }^{10}$ Vgl. http://www.macquariepenanthology.com.au/aust_teachingguide.htm.

${ }^{11}$ Ebd.

12 Vgl. http:/www.proprofs.com/quiz-

school/widget/v2/quizshow_w.php?quizid $=64138 \& q u . .$.
} 
Q. 23) Former Prime Minister Paul Keating in his speech The Ghost of the Swagman stated that the next best thing to rain in a drought was what?-
A. Humour,
B. Music,
C. Patriotism,
D. Dreams.

Q. 29) Peter Carey's first novel Bliss was published in 1981. His first collection of short stories published seven years earlier, was title [sic] The ----- Man in History.-
A. Rich, B.
B. Ignorant,
C. Fat,
D. Super.

Wer sich an den Film The Dead Poets Society erinnert, gerät ins Grübeln, welches pädagogisch wertvolle und für die Lebenswelt von Jugendlichen relevante Wissen hier mit Hilfe der Literatur vermittelt werden soll.

Sollte die Literatur Australiens nach der 'Krise', die sie selbst durch den Rückzug auf das Nationale, den Verzicht auf die Hervorkehrung ihrer kosmopolitischen Offenheit sowie auf eine einleuchtende Begründung, weshalb jemand außerhalb der Grenzen des Landes ausgerechnet sie und nicht eine andere - und auf Kosten welcher anderen Autoren und Werke - studieren soll, verursacht hat, (zurück) ins universitäre Curriculum finden, dürfte die vorliegende Anthologie nur einen bescheidenen Anteil daran haben. 
David Sornig: Spiel. UWA Publishing, 2009. 245 pp. ISBN 978 192140125 1. By Adèle Garnier, Universität Leipzig/ Macquarie University.

Two decades after the Fall of the Wall, the city of Berlin and its East German past continues to intrigue Australians. Florian Henckel von Donnersmarck's German feature film Das Leben der Anderen (The Life of Others, 2006) and Anna Funder's Australian non-fiction Stasiland - True Stories Behind the Berlin Wall (2002) have met with critical acclaim and commercial success in Australia. (The film made more than US $\$ 2,4$ millions at the Australian box office as of 2007. See webreference. The book also won the 2004 British Samuel Johnson Prize for Non-Fiction). Like Das Leben der Anderen, David Sornig's Spiel is a Berlin-based fiction in which the activities of the East German secret police inspire a reflection on fact and fancy, authorship and agency. Like Stasiland, Spiel is narrated in the first person by an outsider, an Australian confronted with the ghosts of the German past. Yet, more explicitly than both Das Leben der Anderen and Stasiland, Spiel explores the personal journey of its narrator, and, to an extent, of its author. The narrator's inner life as well as his Australian upbringing feature prominently in the novel. Moreover, Berlin's imperial and national-socialist legacy resonates throughout a story that emphasises the Cold War years of the German capital.

Spiel is David Sornig's first novel. Born 1969 in Melbourne, Sornig is an academic and writer of German and Austrian descent. In 2008, he was awarded the Charles Pick Fellowship at the University of East Anglia; currently he lectures at Adelaide's Flinders University. Sornig has visited Berlin several times since the early nineties and evokes his Berlin visits on his blog, see http://davidsornig.wordpress.com. Spiel's narrator is a Melbournian architect of German origin in his late thirties who travels to Berlin after the death of his German-born uncle Hans. The narrator is not attending his uncle's funeral; Hans died in New South Wales. Rather, the news of his uncle's death urges the architect's escape from a carefree life gone awry. In Berlin, the newcomer is confronted with fantastic, dangerous and 
multi-layered tales and places. The novel's structure is non-linear. Written entirely in the present form, Spiel intertwines the narrator's sojourn in the German capital, his Australian biography, and a recollection of Staatssicherheit reports that gradually relates to the two other narrative threads.

Spiel's Australian sequences portray the narrator's life in suburban Melbourne. We follow his tormented relationship with architecture. Triggered by his uncle Hans, his schoolboy's revelation to the art of building evolves into nihilism as a career student, as his smug fascination for Nazi architect Albert Speer wins him a following amongst outcast undergraduates. Yet the main focus of the Australian scenes is on women: Annie Rivers, the narrator's provocative school friend and occasional lover, Veronika, his hardworking wife who appears increasingly disappointed with her underachieving, manipulative husband, and an East German childhood pen pal named Rosa Stumm. Rosa Stumm never answers the letters of the young narrator. The Australian episodes gradually contextualise the narrator's quest for a blind woman in Berlin. The architect meets the woman as he arrives at Bahnhof Friedrichstraße on New Year's Eve. She talks him into agreeing to play a game without knowing what is at stake. She then takes him to a performance of Mozart's Magic Flute at the Komische Oper, yet insists on leaving the theatre after the first Act. As they leave, the building is destroyed by a bomb blast. Later, the narrator awakes in the blind woman's flat. She is gone. Before she disappears, the woman asks him to tell her who she is. He names her Rosa Stumm, after his never answering East German pen pal. The narrator's intercepted, partly censored, letters to Rosa fill up Spiel's 'Stasi files' chapters. In his letters, the young narrator names himself Karl. 'Karl' wonders what it is like to live on the other side of the wall, confesses his fear of a new world war, describes his awkwardness with his German heritage, which he fantasises as Nazi. Like 'Karl', 'Rosa Stumm' is a surrogate identity. As reported in the Stasi files, Rosa Stumm is the name given to a Berlin girl who has lost her memory and sight after having almost drowned in the Spree in the early 1980s. The Stasi files give an account of Rosa's increasing rebellion against the dominant East German ideology as she grows older. Throughout his sleep-deprived wandering in Berlin-Mitte on New Year's Day, 'Karl' is as much confronted with the possible non- 
existence of Rosa Stumm as with the apocalyptic history of Berlin, the palimpsest city.

Spiel's sinuosity mostly benefits from Sornig's singular writing style. At its best, the novelist effortlessly combines a dreamlike symbolism with a details-focused narration replete with names, places, colours and sounds - Spiel's 'soundtrack' is further explored on the above mentioned blog of the author. This sensual style allows for evocative renderings of both a sweaty, sunburnt Australian suburbia and a cold, dark and magical Berlin. One of the strongest chapters of the novel deals with the ultimate revelation of Rosa Stumm's identity. Almost entirely recounted through dialogues, the sequence masterly entangles individual and collective memories while giving the Stasi reports a cathartic, disturbing significance. At times though, Spiel's name-dropping rather proves redundant and weighs on the already complex plot lines. The reviewer, more familiar with the German capital than with Melbourne, found it more irritating in the case of the Berlin chapters than of the Australian episodes. Yet frequent dialogues as well as the 'Stasi files' chapters cleverly interrupt the narrative rhythm.

Spiel is a gripping read and Sornig's distinct literary voice obvious. The novel enriches contemporary Australian literature encountering the European past, such as, besides Anna Funder's Stasiland, Christos Tsiolkas' Dead Europe (2005) and Steven Conte's The Zookeeper's War (2007). Spiel can also be read as an Antipodean homage to Jorge Luis Borges and Franz Kafka. As such, the book might especially appeal to readers who enjoy tortuous and introspective mysteries blurring the line between fiction and reality.

\section{References}

Conte Steven, The Zookeeper's War. Sydney: HarperCollins, 2007.

Das Leben der Anderen. Produced by Max Wiedemann, Qurin Berg and Dirk Hamm, written and directed by Florian Henckel von Donnersmarck. Germany 2006.

Funder Anna, Stasiland - True Stories Behind the Berlin Wall. Melbourne:

Text Publishing, 2002.

Tsiolkas Christos, Dead Europe. Sydney: Vintage/Random House, 2005. Webreference, Stasiland box office takings:

http://www.boxofficemojo.com/movies/?page=intl\&id=livesofothers. htm.

Webreference, Samuel Johnson Prize:

http://textpublishing.com.au/books-and-authors/book/stasiland/. 
Ouyang Yu, The Kingsbury Tales. Blackheath, NSW: Brandl \& Schlesinger, 2008. 102 pp. ISBN: 9781876040826 Price: not given. By Igor Maver, University of Ljubljana

W hy do Geoffrey Chaucer's The Canterbury Tales still represent an appropriate twentieth-century narrative framework with the Australian literati is anybody's guess? Christina Stead with her book The Salzburg Tales (1934) only very loosely followed Chaucer's structure, where the 'pilgrims' attending the Salzburg Summer Festival are in real and mythical settings motivated by their various social backgrounds, cultural and musical tastes. And now there is Ouyang Yu with his "verse novel" (15) The Knightsbury Tales and his intercultural/ transcultural travellers between China and Australia, a book that is "no match / For The Canterbury Tales" (15). Pilgrims are always a good opportunity to bring together people from various walks of life, a cross-section of society, which is also the case with Yu's multicultural and multiethnic Melbourne, where he lives part of the year while away from his home country China. Almost each poem featured in these 'tales' juxtaposes China and Australia, their relations and the poet's own life caught up in the precarious migrant web of time and place. Almost each poem explores the various characters in present-day Australia, wives, concubines, lawyers, diplomats, students, professors, factory workers, mental patients and foreign visitors, each from a colonial and post-colonial point of view, many presenting historical and non-historical figures from the time of the First Opium War (1840) to our very present.

Yu's first programmatic poem in the collection makes it clear right at the beginning that the poet/the narrator is a cheeky and most versatile Chinese-Australian (or the other way around) trickster, whose art goes undisputed through the whole book: he chose the novel form to be written, "For novel readers / To get novel grant(s) / At the moment" (16). Perhaps the guess mentioned earlier is not all that unusual if one considers the fact that The Knightsbury Tales in Chaucer's format, including the rhetoric, lowbrow and bawdy 
elements, are really the reflections of Ouyang Yu's own life story, himself an intellectual, cultural (and political) pilgrim down under, which represents a cross-section of society and Chinese-Australian cultural relations. Cultural translation, transformation and the fact of being caught up between cultures are the main themes in The Knightsbury Tales: his intellectual estrangement in the new environment made him for a long time feel a total stranger, as he says in an interview, and he "had to kill /himself/ spiritually in order to gain a new life linguistically, culturally and spiritually". The newly found freedoms in Australia and its democracy (which he punningly calls "demoncrazy") soon made him disillusioned in the everyday routine of unfulfilled expectations and turned him into an angry poet, employing an acerbic, funny and very political poetic style, which most critics of his work have noted. Anger can, however, also represent a new beginning and it has indeed given rise to his impressive literary production to date (poetry, fiction, non-fiction, literary translations into Chinese), which is unique in Australia's contemporary literary landscape.

Yu came to Australia from China in 1991 to study Australian literature. He obtained a PhD from La Trobe University and established himself in Australia as a poet, fiction writer and translator who has received several literary prizes. As a translator of some of the major Australian texts into Chinese he acts as an important cultural mediator between the two countries. As a counterpart to the leading Australian cultural review Overland, he established Otherland, Australia's first Chinese-English literary journal. He is a Professor of Australian literature and Director of Australian Studies centre in the English department at Wuhan University in China. As he divides his time between Melbourne and China, his dividedness is very central also to his literary experience. The poems are thus a literal (and literary) site of collision between the two cultures, Chinese and Australian. The language he uses clearly illuminates this process: funny and laden with suggestive sometimes cacophonic references, $\mathrm{Yu}$ uses Australian English to explore all the poetic potentials of the differences, similarities and parallels between Chinese and English in a distinctly Australian context, using many Chinese words as well. As the poet John 
140 IS eite Igor Maver

Kinsella writes in his introduction to the collection, $\mathrm{Yu}$ through his rhetoric of "devastating images" creates a new language and new poetry altogether: "A new Australian poetry, a new Chinese poetry" (8).

Yu wrestles with sexual desire and love, both poignantly enticing, the former sometimes touching upon the perverse and Chauceresque bawdy ("Ms Cui's Tale", 31-2). The poet is also trying to deconstruct the negative (hetero)stereotypes that had been created in Australian literature, where they were essentially demonised, made look dirty and sinful: many Chinese names employed in the past contained the word "Sin" with the allusion of sinfulness amongst the 'heathen' Chinese. He takes as a cue for "Two Bulletin Tales" the 14/4/1888 short story entitled "Mr and Mrs Sin Fat" by Edward Dyson, published in the ('male') Bushman's Bible The Bulletin. He does not see much change since then, however, himself going through the same kind of prejudice-based publishing ('female') policy as he imagines the Chinese went through more than a hundred years ago:

But hang on and listen to my other male newspaper story that happens today

In which this female editor emails to say, in her response to the submission

Of something I wrote: 'I'm afraid we can't place this piece'

I wonder if the then male editor of the male newspaper had said something similar

Or in a more honest Aussie manner: I'm sorry, 'Mr Sin or Mr Fat But I'm afraid we can't place this piss as we are full (of shit) till the end of 1888' (20).

In "An Aboriginal Tale" (21-2) Yu directs his rage over racism at the novels Capricornia and Poor Fellow my Country by Xavier Herbert, which he finds excruciatingly anti-Aboriginal in constructing the image of the ignoble savage:

Last night I thought of photocopying the pages where Suvitra Is killed, raped and eaten by the Aborigines in Poor Fellow My Country

And mail them to him but, in the end, I gave up on the thought, putting the book away Never to be read again (22).

The twelve clusters of 'tales' in the verse collection under review here (e.g. Historical Tales, Artists' Tales, Philosophical Tales, Wuhan Tales, The Empire Tales), there are also Migrants' Tales. These 
poems, which always contain clear political implications, reflect all the multiethnic diversity of Melbourne's Kingsbury area: "In Kingsbury, English is not the only spoken language / Chinese, for example, is one of the many spoken, and written as well as read / Languages" (58). Ouyang $\mathrm{Yu}$ is throughout very funny, anticonsumerist, and as a person split between two countries and civilizations, at the same time anti- and pro-Australian and Chinese as well, accepting the best of both worlds. The first of his "Wuhan Tales" speaks about the speaker's own (intellectual) defection back to China from the Australian Western 'demoncrazy', because of his diappointment with some aspects of Australian 'repressiveness' as regards the humanities (and scholars like himself who cannot get a proper job), as he claims in an interview.

Yu's poems are the reflections of a displaced poet who translates his life experience into two systems, a poet of the in-between, split between two (non)homes, where Home is stripped of its spatial dimension. In his poem "An Oz Tale", which reads like a companion piece to A.D. Hope's iconic poem "Australia", a desert country from which "prophets come" as Hope would have it, Yu describes Australia as
a land of mental darkness
Where the core values are metallic...,
a non-home kept there for you to return to, again and again
Oz, Oz, Oz / Oi/ly, Oi/ly, Oi/ly (96),

a land where no prophet is in sight. Despite the stark accusations of Australia's "mediocrity kept alive as a national treasure" (96), the poet still laments his departure and expresses yearning for the land every time he leaves it left behind: he dwells just as ambivalently in his affective allegiances to "her, him" as does Hope in his famous poem. Ouyang Yu's verse is all but light and easy on the senses: yet it makes one alert to the ethical and political ramifications of the contemporary Australian cultural condition. A powerful new Australian poetic, a read not be missed. 
Michael Cathcart: The Water Dreamers. The Remarkable History of Our Dry Continent. Melbourne: Text Publishing, 2009. 319 pp + index, A\$ 29.95. Isbn: 9781921520648. Reviewed by Adi Wimmer, University of Klagenfurt

heard Michael Cathcart give a paper in 1997 which was
thematically related to this book. An interesting paper, but what I
remember best about it is how entertaining its presenter was.
Everybody was rolling around with mirth. So I approached this study
with great expectations.

Michael Cathcart is a senior Researcher at the University of Melbourne's Australia Centre. He trained as a historian and geographer and worked for five years with the $A B C$, where he presented the daily Radio programme Arts Today. On ABC TV he was visible as the host of a 15-part series "Rewind", which investigated little-known vignettes from Australian history (www.abc. net.au/tv/rewind/txt/s1162957.htm.) There was also a 2-part TV documentary on early colonial crime, titled Rogue Nation. ${ }^{1}$ This special talent he has for winkling out stories from the past ranging from the unheard-of to the 'bizarre' is much in evidence in the present study, studded as it is with yarns, furphies and anecdotes.

We have had a number of hydrological studies on "the dryest continent", but this one is far more ambitious than anything before it. Cathcart attempts no less than to re-write Australia's history from the perspective of its often deliriously unrealistic hopes for an abundance of water where there was none. If I may just single out one of these unrealistic hopes, or rather, expectations: As late as in 1945 the engineer L.H. Lascombe "proposed a canal linking Spencer Gulf with Lake Eyre to create a salt-water inland sea" (184). On the plan he drew up for his mad-cap scheme Lake Eyre is heart-shaped, a reminder that until about the middle of the $20^{\text {th }}$ Century, Australians viewed Lake Eyre as the "heart" of their continent, not

\footnotetext{
${ }^{1}$ www.australian.unimelb.edu.au/aboutus/people/cathcart.html.
} 
Alice Springs or Uluru. Not only would the canal have been five times the length of the Suez canal with appropriately staggering costs; once completed, of what possible economic use could it have been?

Cathcart starts out with a 40-page history of the Sydney Cove settlement - from the perspective of its water supply. Sydney once had the 'Cadigal' (later re-named the 'Tank') river, a quite substantial rivulet. The settlers managed to first foul it up and then to make it wither away in just 3 years. Water had to be got from further inland, from a swampy area called the Lachland swamps. (Today Centennial Park occupies this area.) The settlers managed to turn the swamp into dryland. So bores had to be sunk into the land. Once again, the settlers were so profligate with water most bores very quickly ran dry. Even though Sydney has more precipitation than London ( $1200 \mathrm{~mm}$ as opposed to $600 \mathrm{~mm}$, so Cathcart claims), Sydney's porous sandstone made for dryer soil conditions than back in England. Nor did it help that the early settlers were possessed by a veritable mania for axing trees.

Axes are an important Leitmotif. What early explorers of the bush and early Australian poetry - noted about it was its silence. Today, we connote silence positively. Not so in the early $18^{\text {th }}$ Century. The as-yet to be explored continent was forever labelled "melancholy", "mournful"; "funeral", "secret" and a "silent wilderness." This silence had to be broken through the colonial enterprise. It was almost as if the British were seizing the land through noise. Once again colonial poetry provides material for this insight: in poem after poem, the sound of a "ringing axe" perturbs the Aboriginal silence of their seemingly inactive, unproductive land. Axes were freely given away to Aborigines, we are told. Clearly the British were hoping they would fell trees for them. (One is reminded that 15 years ago, the governor of a Brazilian province gave away chainsaws to a ragbag of buccaneers so that the rainforest be cleared and vexatious indigenous people be 'dispersed'.) In 1828, a ceremony was held by a boatload of pioneer settlers on the shore of the Swan River. The wife of the Chief Naval officer symbolically felled a gum tree, thus 
144ISeite Adi Wimmer

claiming possession of the land: "Axes and saws proclaim the dawn of civilization" (60/1)

The lion's share of this study is devoted to the most significant of mid-19 ${ }^{\text {th }}$ Century explorations. They were, according to Cathcart, a search for Australia's mythic inland sea. Elaborate maps exist of this imagined inland sea - or lake - with fanciful names such as "The Desired Blessing." Time and again a hopeful expedition got stuck in the inland desert, sometimes barely making it back to civilization. But Australians collectively refused to accept their continent's interior was barren. It HAD to have potential, it HAD to be arable if one only applied the right watering technology. The way the author sketches and comments on the follies of various cuckoo-cloud 'scientists' and explorers is both astonishing and painfully humorous. They are the "Water Dreamers" of the book's title. Elsewhere Cathcart sees them as "Lemurians" who

affirmed an uncomplicated optimism about the future of Australia, a confidence that death and melancholy could be washed away by irrigation and the exploitation of the great artesian basin (190).

Cathcart is surprisingly astute (for a scientist) when creating meaning from colonial poetry and fiction. Of the "mournful silence" so often contained in the former I spoke already. How about colonial prose? Cathcart boldly claims the collective unconscious is present in the bulk of Australian novels of the second half of the $19^{\text {th }}$ Century. How so? Because Australians, in their efforts to construct for themselves a national identity free from British paternal influences, had to construct the idea of a continent that was prosperous and full of hope. How could they have identified with a barren land? How could they possibly be weaned off from the idea of being British when only that "Scepter'd Isle" possessed pastures of green and plenty? He presents us with an array of adventure novels modelled on American frontier narratives particularly of one genre, that of eradicating the horrible 'Injuns'. Novels that describe how a tribe of blacks lives on the shores of an inland sea and they are governed by a white. It is curious how many such narratives fancy native tribes as governed by a white leader who is never a Brit. The British could not be corrupted by tribalism, but an Irishman 
or a Norwegian might be. Or how intrepid white explorers engage in gun battles with murderous Aborigines over possession of waterholes. Such tales propagate the national discourse of bringing the "silent" land into history and prosperity. And often the success of these explorers hinges on the discovery of a lake, a river, an inland bight connected to the Timor Sea by an undiscovered channel.

To the epic folly of Robert O'Hara Burke's expedition Cathcart adds no new aspects, but in discussing the totally overblown ceremony of grieving and monumentalizing afterwards he adds an important observation on the collective Australian unconscious of the time, namely that to accept a defeat as a defeat was unthinkable. Burke and Wills had to be heroes, had to have achieved "the great objective .. of crossing the continent of Australia for the first time". With biting sarcasm Cathcart adds that the route Burke had pioneered was totally useless. In view of these indisputable facts, it seems yet another madness that Australia's National daily The Australian is currently engaged in planning a re-enactment of Burke and Will's deathtrip, which will have its $150^{\text {th }}$ anniversary in the second half of 2010 .

Possibly the most gripping narrative in this study concerns the illfated attempt of Charles Sturt to find the mythical inland sea in 1844 (128-47). Reading it, I was reminded of the final pages of Patrick White's Voss, in which the reader is made to experience empathy with Voss in his dying days. Sturt's suffering and that of his men bedewed my brow. Like in the Burke/Wills expedition, the men had been badly chosen for the job: the majority were ruffians with a taste for the grog. But then there was also Daniel Brock, a Godfearing Methodist, who loathed them. Brocke confided seditious thoughts to his diary: "An Englishman is a curse to the Aborigines of any country." More specifically he added that "the white man has been here cruel, more cruel, than any savage." Sturt himself, ready to sacrifice his own life and that of the men in his care for an enterprise of empire, after a futile, benighted struggle that was described as "heroic" afterwards, found solace in an equally 'seditious' notion: that Nature had "intentionally closed itself upon civilized man" so that Aborigines would be able to "roam over it in 
freedom." Sturt was surprisingly respectful in this insight. In other respects he was ridiculous. Wondering why he chose such an illsuited crowd of ruffians for his expedition, Cathcart finds the reason for two of his choices. One man was called Poole, the other Flood. Their names betokened water and Sturt took that as a good omen.

Like Herman Melville's Ishmael, Cathcart time and again strays from his straight line, offering forays into unexplored territory. Perhaps the most unexpected detail of this rich study (see 140-1, so it crops up right in the middle of the Sturt expedition) is a correction to an argument created by Kay Schaffer in her well-known feminist study Women and the Bush (1983). Schaffer cited from Major Mitchell's diaries, in which he allegedly wrote: "Of this Eden I was the only Adam, and it was indeed a sort of paradise to me". He did not. Together with a typically feminist (mis-)reading of Mitchell's verb to "penetrate" (his meaning was militaristic, not sexual), Schaffer constructs the argument that in the eyes of early male Australians, the land was like a virgin to be conquered and penetrated. Did not Mitchell also write that he was attempting to lift "the veil" that hung over this land? Once again, he was not referring to a bridal veil but to the then common term for 'flynet'. The embarrassing truth is that Mitchell never wrote these sentences. Schaffer quoted them from a bowdlerized school textbook of 1928 in which the editor had changed some passage for greater effect. "Adam" was not in Mitchell's original diary. Nor was Mitchell's personal pronoun for the land "she", it was "it." Much of Kay Schaffer's argument falls flat to the ground.

In the final chapter "New Beginning", Water Dreamers chronicles the developments since 1995, the year that the "Murray-Darling Cap" was introduced. The measure had been triggered by an unprecedented environmental disaster in 1991. Since so much water had been taken from the Darling river, its flow came to a virtual halt and a toxic mass of blue-green algae clogged a stretch almost 1.000 km long. The "Cap" was designed to allow more water to flow towards the sea. But it was not sufficient. The ecosystems further down the river were extremely toxic with salt and fertilizers. The only way to save them from collapse was to allow even more water 
to remain in the river. Australia's most prominent environmentalist Tim Flannery (read the review of his An Explorer's Notebook in ZfA 2009) called for halving the amount of agricultural water that was to be taken from the Darling, and a massive buy-back operation by the government. This happened: The Howard government spent 3 bn A\$ to buy water back from farmers who had purchased it for their crops. True to its neo-con bent, the government had a solution: Water trading. Now the Murray Darling water is a commodity just like coal or gold or copper. Cathcart has this to say: "The idea of buying water so that it can run downstream is bizarre." Quite. As is the idea of buying the 'right' to pollute the atmosphere with millions of tons of carbon dioxide.

If I have any quibbles with this excellent and highly readable book it is that its structure is somewhat playful. Cathcart has too many brilliant ideas and he cannot drop any of them for the sake of a more stringent argument. His chapter on "Necronationalism" is a case in point. In it, Cathcart deals with the idea - frequently mooted elsewhere in his study - that for Australians, failure is natural and honourable. Gallipoli is seen as a case in point. And this is supposed to come from the experience of failing to find lush pastures and bodies of water in the interior! A daring argument. Could the celebration of the disaster that was Gallipoli not have had its origin in the dogged refusal of politicians to admit they had made a dreadful mistake? Cathcart identifies this mindset in the elites of the state of Victoria after Burke's and Wills's bodies were laid to rest in a pompous ceremony. Celebrating a mistake is a way of concealing its true nature.

But this is mere nit-picking, I suppose. All in all, the book is to be strongly recommended: for its factuality, its charts and drawings, and for its ingenuity to retell a story that is partly already know to us, in ways that are not. 
Kate Grenville: The Secret River. Text Publishing (Melbourne) 2005. 352 pp. ISBN 978-1921145254. Kate Grenville: The Lieutenant. Text Publishing (Melbourne) 2008. 307 pp. ISBN 978-1921351785. By Anja Schwarz, Universität Konstanz.

O n 15 February 2010, exactly two years after Australian Prime Minister Kevin Rudd had offered the Apology to Australia's Indigenous People as the first act of the reconvened parliament, the author Kate Grenville was invited to contribute an opinion piece to the English broadsheet The Guardian. In her article, Grenville (2010) looked back on the progress that the project of reconciliation had since made and conceded that while there had been some movement, "the Rudd government can't point to any spectacular policy changes or huge improvement in outcomes." Rejecting the notion, however, that the apology had been just "hot air, a cynical exercise in spin", Grenville discussed the difficulties faced by the government's housing program for Indigenous communities as one example of "just how tangled the problems are." While symbolic acts were never enough, she concluded, the apology remains an "overdue and necessary first step."

This was not the first time that the author was asked to speak on behalf of Australian reconciliation abroad or at home ${ }^{1}$ and, indeed, her role as The Guardian's expert on reconciliation 'down under' is hardly circumstantial. The article introduced Grenville as "an awardwinning Australian author," and the British paperback edition of The Lieutenant, her latest novel portraying the first years of Australia's colonial history, had been published and reviewed in the same newspaper (Housham 2010) only two weeks earlier. It seems that her creative preoccupation with this period in history has authorised Grenville to become a sought-after commentator on the process of Australian reconciliation; a commentator who occupies a particular

\footnotetext{
${ }^{1}$ See, for instance, N.N., 2009.
} 
discursive position: that of the settler-descended Anglo-Australian sympathetic to the Indigenous cause.

The Secret River (2005), the first of the two novels that earned Grenville this claim, relates the story of William Thornhill, a convict roughly modelled on the figure of Grenville's own great-great-greatgrandfather, who is transported to the colony of New South Wales in the first decades of the nineteenth century and who, after his pardon, settles on the Hawkesbury River. Here, he rises from poverty to affluence and falls in love with the country he now calls his own. All throughout the book, there is ongoing and eventually violent conflict with the local Aboriginal people, whom Thornhill and his neighbours eventually 'disperse' in a gruesome massacre. In her memoir Searching for the Secret River (2006) Grenville locates her decision to write about Australia's early colonial history during the Reconciliation Walk across Sydney Harbour Bridge in May 2000, a grassroots event that drew a quarter of a million participants and was organised in defiance of the Howard government's unwillingness to offer a state apology to Australia's Indigenous peoples. In a passage from this memoir, Grenville describes her encounter with a group of Aboriginal men and women who are not walking but watching:

At the end of the row, a tall handsome woman frankly staring, as if to memorise each face. Our eyes met and we shared one of those moments of intensity - a pulse of connectedness. [...] It should have made me feel even better about what I was doing, but it sent a sudden blade of cold into my warm inner glow. This woman's ancestors [...] might have been living on the shores of Sydney Harbour when the First Fleet sailed in. The blade I was feeling was the knowledge that my ancestor had been there too. [...] He'd have come ashore right underneath where an Aboriginal woman and I were exchanging smiles. (12)

The passage is paradigmatic for the manner in which Grenville has related to both of her novels in public. Cross-mapping onto the past the contemporary Harbour Bridge encounter and the politics of reconciliation that inform it, this passage shows her concerned not only with the construction of her own author-persona as someone 
engaged in reconciliatory politics ${ }^{2}$ but also with the establishment of a particular understanding of the relationship between past and present that merits further investigation.

Similar to its predecessor, The Lieutenant is based on historical figures. It has variously been described as "a companion piece" (Guest 2009; Cross 2009) to The Secret River that "walks similar ground" (Daily Examiner 2008) and engages with many of its predecessor's themes, "but from a different perspective" (Shilling 2009; Parini 2009). Grenville herself (N.N. 2008a) speaks about both novels as mirror-images of each other, "a kind of ying and yang", explaining that "[t]he early days of settlement in Australia seem to have been the best of times and the worst of times, bringing out both the glorious and the terrible in people." The two novels jointly explore this duality: while The Secret River focuses on the violence characterising early settlement, The Lieutenant allows Grenville to tell the story "about two people who find a way to start speaking to each other."

The Lieutenant fictionalises the prolonged encounter between New South Wales' first astronomer, William Dawes (renamed Daniel Rooke), and the Indigenous girl Patyegarang (recast as Tagaran) in the closing decades of the eighteenth century. To this day, Dawes remains relatively well-known as one of the very few historical actors in the history of early colonial Australia who, as Cassandra Pybus (2009: 12.1) remarks ironically, "can inspire a universally good press from historians." The astronomer appears to have been an outsider to the first European settlement on Australian soil. What earned him his exemplary status (Clendinnen 2003; Flannery 1999; Mander-Jones 1966) is the fact that he slowly learned the language of the Cadigal people and was eventually stripped of his rank and sent home for refusing to take part in a punitive expedition to Botany Bay following spearing of the colony's gamekeeper. Dawes notebooks, extensively documenting his conversations with Patyegarang, were re-discovered in a London archive in 1972.

\footnotetext{
${ }^{2}$ See Tom Griffiths (2009: 74.4-74.7) for a critical comment on Grenville's self-staging techniques in Searching for the Secret River in particular with regards to the proclaimed difference of her project from that of historians.
} 
In promoting The Lieutenant (2008), Grenville again has named the concerns of the present as motivating her writerly interest in the past. Eight years after the walk across Sydney Harbour Bridge however, her point of reference is no longer the opposition to Howard's conservative politics but Kevin Rudd's apology. In a statement that is posted on her publisher's website together with a short video clip (Grenville 2008a), Grenville describes the book as "not just another historical novel":

You know, in 2008, post Kevin Rudd's apology, we are entering another kind of Australia and another kind of possibility for dialogue between black and white is opening up, I think for the first time in 200 years, for the first time since Dawes had his conversations with Patyegarang. So in a way, I am thinking that his story tells us something that might be useful for us going into the future. ${ }^{3}$

Claiming that something 'useful for the future' can be learned from the story of Dawes and Patyegarang's historical encounter, Grenville invites readers to understand her novel as involved in the apology's reconciliatory, nation-building project. As she had done for The Secret River, she claims relevance for The Lieutenant beyond the immediate fictional content; a meaning that emerges both from the insights into the past that her novels promise to deliver and from the respective bearing that these insights have on the contemporary process of reconciliation.

And the novels have been debated precisely on these terms: less for their literary merit than for their engagement with reconciliation on the one hand and the 'history wars' among Australian academics about the nature of the country's colonial past on the other. It is therefore not surprising that Grenville's assertions brought to the defences a number of historians, tired, as Mark McKenna (2005) put it, of "[t]he rise of the novelist as historian, of fiction as history". Her claims for the political and historical relevance of her novels, these critics felt (see McKenna 2005; Clendinnen 2006 and Hirst 2005), illegitimately crossed the line between imaginative fiction and evidence-bound history.

\footnotetext{
${ }^{3}$ For one among numerous other statements by the author that make a similar claim see Metherell, 2008.
} 
While these "robust and telling critiques" (Griffiths 2009: 74.8) by prominent Australian historians of Grenville's sentimental and sanitised portrayal of colonial history certainly make good reading, it might ultimately be more productive to understand Grenville's project, as Kate Mitchell does in her reading of The Secret River, not in terms of wanting to accurately represent what happened in the past, but as attempts at reconciling the author's sense of that past with the changing public uses of the past in the reconciliatiory politics in the present. With the novel, Mitchell explains (2010), the author sought to "rewrite her family story in a way that repositions Grenville herself, taking account of her "swivelled" sense of identity." This interest in the functions of colonial memories in the context of Australia's contemporary phase of transition also appears to have been on the mind of The Australian's literary critic, Stella Clarke (2006), when she defended Grenville against the allegations of historians. As a nation coming to terms with its colonial past, Clarke argued, "we [Australians] need all the help we can get."

\section{Bibliography}

Clarke, Stella, 2006. "Havoc in History House." The Australian (4-10 March).

Clendinnen, Inga, 2003. Dancing with Strangers. Melbourne: Text Publishing.

Clendinnen, Inga, 2006. "The History Question." Quarterly Essay 23, 1-72. Cross, Stephanie, 2009. "Literary Fiction." Daily Mail, (30 January).

Flannery, Tim, 1999. "Introduction" In: Flannery, Tim, ed., The Birth of Sydney. Melbourne: Text Publishing, 1-42.

Grenville, Kate, 2005. The Secret River: Melbourne: Text Publishing.

Grenville, Kate, 2006. Searching for the Secret River. Melbourne: Text Publishing.

Grenville, Kate, 2008. The Lieutenant. Melbourne: Text Publishing.

Grenville, Kate, 2008a. "Kate Grenville on The Lieutenant." Available at: <http://www.youtube.com/watch?v=kH9-LexkRz4>.

Grenville, Kate, 2010. "A True Apology to Aboriginal People Means Action as well: Australia's Prime Minister was Right to say Sorry, but Two Years on Little has Changed for the Better in Indigenous Communities." The Guardian (15 February).

Griffiths, Tom, 2009. "History and the Creative Imagination." History Australia 6(3), 74.1-74.16. 
Guest, Katy, 2009. "Uplifting Tale of a Quiet Man Who Sees Truth in Words." The Independent (20 February).

Hirst, John, 2005. Sense and Nonsense in Australian History. Melbourne: Black Inc.

Housham, Jane, 2010. "Review: The Lieutenant, by Kate Grenville." The Guardian (30 January).

Mander-Jones, Phyllis, 1966. "Dawes, William (1762-1836)." Australian Dictionary of Biography, vol.1. Melbourne: Melbourne University Press, 297-298.

McKenna, Mark, 2005. "Writing the Past: History, Literature and the Public Sphere in Australia." Public Lecture held at the Queensland College of Art, Brisbane (1 December). Transcript available at: <http://www.humanitieswritingproject.net.au/mckenna.htm>.

Metherell, Gia, 2008. "Chance Discovery Inspires Latest Novel." Canberra Times (31 October).

Mitchell, Kate, 2010. "Australia's 'Other' History Wars: Trauma and the Work of Cultural Memory in Kate Grenville's The Secret River." In: Kohlke, M.L. and Gutleben, Christian, eds, Neo-Victorian Trauma. Amsterdam and New York: Rodopi (forthcoming).

N.N., 2008. "Troubled relations." Daily Examiner (8 November).

N.N., 2008a. "An Interview with Kate Grenville." Available at: $<$ http://kategrenville.com/The_Lieutenant_Interview>.

N.N., 2009. "Acknowledge the Aboriginal Wars with a Memorial: Grenville." Australian Associated Press General News (2 March).

Parini, Jay, 2009. "Heavenly and Earthly Bodies: Kate Grenville Repossesses History in a Story of Sea, Stars and Settlers." The Guardian (31 January).

Pybus, Cassandra, 2009. "'Not fit for your protection or an honest man's company': A Transnational Perspective on the Saintly William Dawes." History Australia 6(1), 12.1-12.7.

Rudd, Kevin, 2008. "Apology to Australia's Indigenous People." House of Representatives Official Hansard, 1 (13 February). Available at: <http://www.aph.gov.au/Hansard/repsldailys/dr130208.pdf>.

Shilling, Jane, 2009. "A Deft Historical Tale of Discovery - of Both a New Continent and of the Explorer's Own Self." Sunday Telegraph Magazine 'Seven' (25 January). 


\section{Marina Larsson: Shattered Anzacs: living with the scars of war. University of NSW Press: Sydney 2009. Reviewed by Josef Berghold, University of Klagenfurt}

Marina Larsson's new and compassionate study sets out to fill an important gap in the historical analysis of the First World War. On the one hand, the author complements a growing corpus of studies which investigate the emotional impact of this war, personal and collective, and ranging from the battle front to the home front. Several studies have examined loss and grief in connection with official commemorations for fallen soldiers; others have investigated the long-term effects of war trauma, including shell-shock. Larsson's unique contribution is to adjust the emphasis of the emotions from the fallen soldier or war widow to the families or kin of wounded soldiers. As she writes, "Thousands of Australians have a 'shattered Anzac' in their family history" (17). Thus in a way her study of physically and mentally impaired Australian soldiers is also an ambitious study of twentieth-century Australian family history. Indeed, on page 280 we discover that Larsson's grandfather was severely wounded after "being at the front for only a matter of weeks" (279) and shortly thereafter "invalided home to Australia."

The book is organised chronologically. After an introduction that outlines how this is not only a study of war-time disability but also a life-history of invalid veterans and their caregivers, chapter one begins with the first decision of young Australian men (often in discussion with their family) to enlist. According to Larsson,

During the war, 40 per cent of Australian males between the ages of eighteen and forty joined up [...] including 50 percent of all single eligible men" (32).

Larsson then briefly explores many reasons for joining or not. For example, "Men who remained at home cited a fear of death and disablement as well as a complex array of personal and situational reasons, including family responsibilities, pacifism, and business commitments" (34). Many of those who enlisted-in part due to crucial financial considerations (ibid.) - openly admitted to fears of death or 
disablement, as did their families on their behalf. Larsson then takes great pains to elaborate the emotional bond of hope, anxiety, fear, and support, once the son, brother or husband is serving, or at the first injury, basing herself, for example, on war correspondence found in personal papers at the Australian War Memorial Archives or the National Library of Australia and on published collections of letters memoirs and letters. Larsson also points out the silences in many letters, including those which were largely not censored by military hospital authorities, as well as possible discrepancies between a wounded soldier's letter and that of his nurse. Much of this chapter also establishes the pervasive Edwardian codes of manliness to which these men and their family members apparently strongly adhered.

Chapter two continues the journey home: both in terms of disabled soldiers' reunification with family members-and the hope and trepidation felt on both sides, as a "changed man" has returned, and not the one last seen as "fit"-and of public welcoming ceremonies, demonstrating the official recognition of war service. At the same time, personal recognition might lead to something else altogether, as in this coming together some people also grew apart. For example, Larsson states that "After the war there was a significant jump in the divorce rate" (81), and yet "Between 1919 and 1921, there was a sharp increase in the number of marriages in Australia" (8283).

Chapter three investigates the financial burden placed on returning disabled veterans. In large part, Larsson focuses on the enormous struggles families had to make ends meet-in a society in which men were legally and culturally the family's breadwinners. Indeed, the 'family wage' principle established by the Harvester Judgement in 1907 "recommended that women's wages were set at about 54 percent of the male wage in most industries, even if a woman was the primary breadwinner" (107). With state funding for disabled veterans limited, dependent women (mothers, wives, daughters) were expected to step in as caregivers-sometimes for the remainder of their lives. Moreover, in many cases the disabled soldier alone could 
not earn a decent family living. Thus, the Australian Soldiers' Repatriation Act "effectively consigned the disabled soldier families to the ranks of the working poor" (95), and the Repatriation Department seemed oblivious to the fact that if disabled men could not earn a decent wage, their families were forced into long-term poverty. And yet, "Disabled soldiers with professional or clerical skills often became good providers" (111). Where the State ignored its responsibility, charities such as the Red Cross, the Tubercular Soldiers' Aid Society, the Return and Services League and the Returned Sailors' and Soldiers' Imperial League of Australia moved in-at least for those who were willing or desperate enough to reach out to them.

From Chapter four onwards, as Larsson explores family life in interwar "normality," she makes use of eleven oral history interviews she conducted (mostly in 2004) with select children of disabled soldiers, including her aunt, all of whom were born between 1922 and 1932. Clearly, as the soldiers aged, as families grew, burdens tended to increase. So too might the unseen yet lingering physical and psychological wounds inflicted during war, such as shell shock or tuberculosis, two "cases" which Larsson examines in particular, in terms of the impact not only on the ex-soldier but also on his extended family. Larsson states that "The significance of the family as a therapeutic site for disabled ex-servicemen should not be underestimated" (148).

In Chapter five-which, from the point of view of trauma psychology, I consider the most informative-Larsson observes that the government during the war created a "two-tiered mental hospital system [...] that separated veterans from civilians wherever practicable" (155). Moreover, she argues, most families negotiated hard, if it was deemed necessary, to have their loved one put into the more privileged "military" asylum. This "protected them from the humiliation of being formally labelled 'insane'" (156). However, as Larsson continues, "veterans were not immune from the shame of madness" (157). In the course of her interviews, Larsson discovered that "one of the strongest sentiments to emerge" was the experience of shell shock as "embarrassing and dishonourable" (ibid.). As one inter- 
viewee said, "shell shock was one of the worst disabilities, actually, because the stress and strain you'd been through, before you'd got like that, and the shame, shame, not sympathy but the shame of shell shock" (ibid.). In keeping with a long tradition of idealizing the "heroism" of the battle-field, its far-reaching traumatic impacts could be denied and repressed most forcefully by denigrating their victims as morally inferior human beings, malingerers, or cowards. Shellshocked soldiers therefore "represented the antithesis of Anzac masculinity because their 'mettle' had buckled under pressure, and they had lost their 'captaincy of the soul'"' (160).

In short, Larsson in this study has pointed out and partially filled a very important gap in military, war, medicine and gender studies: the physical and emotional life of disabled First World War veterans, as influenced by the State, which Larsson argues seems to have failed in providing adequate assistance, by veteran charitable organizations, which tended to include the family and/or community in their assessment of need, and of the veterans' family itself, which generally left no paperwork documenting the long-term, day-to-day physical and emotional care. The book is also well stocked with relevant images (especially family photographs), and it is written in a language quite accessible to a general public.

My critical points of this fundamentally more descriptive than analytical study are to be taken as encouragement for second editions and especially further work in this area. For example, the study tends to repeat quite a number of points in similar if not the exact same language within each chapter or in adjoining chapters, or even on the same page (164). And although we read about many multiple individual choices and outcomes, there are still several relevant factors not included. For instance, given that women were so involved as care-takers, Australian women's organizations political and charitable work are hardly mentioned. The same is true for religious organizations and churches. Or would not a "family perspective" be enriched by including more family memories (many of the interviewees had several siblings)? Indeed, one would like to understand why "a greater number of people [...] chose not to participate" in the study 
(274). Furthermore, how do the emotional and financial suffering of a war widow, for instance, compare to the wife of a disabled veteran? One interviewee's family, for instance, experienced both death and disabled survivors. Did no one-veteran or family member-ever question whether the aims of the war were really worth their longterm "sacrifice"? Finally, in discussing "emotional lives," the addition of literature by (social) psychologists on terms such as "shame," "depression," and "trauma" may well complement Larsson's extensive bibliography. 
Cath Kenneally: Jetty Road. Adelaide: Wakefield Press, 2009. 378 pp. \$24.95. ISBN 987-1-86254-829-9. By Beate Josephi, Edith Cowan University.

'Not that. Domestic interiors. Drawing rooms. Private lives. Feminine concerns, ... The small canvas stuff; hothouse emotions...' Those are the books that nurse Desirée, called Des, likes to relax with, as she explains to her superior, Matron Paula Haggerty. Paula, unlike Des or her sister Evie not much of a reader, promises to gives them a try.

Though the interiors aren't very domestic and the houses don't exactly contain drawing rooms, Cath Kenneally's second novel, Jetty Road, is in many ways about private lives, emotions and small canvas stuff. Family in its various forms, siblings, children, nieces, nephews, parents that have passed away, are the web that shapes the lives of Paula and Evie. Set over a period of several months in the last years of the first decade of the $21^{\text {st }}$ century the novel has, apart from family, a second bedrock: the city of Adelaide.

Evie is the oldest, as was not unusual for a good Catholic Irish family, of four other sisters and a couple of brothers. Single, in her mid forties, she still cuts an attractive figure. Mostly clad with clothes from op-shops, which is as much as she can afford, there is an air of eternal hippy-dom about her. Having come back from years of living in Melbourne, nothing is really fixed in her life. Evie takes frequent walks in her neighbourhood to assure herself of all the places she knows, and in some ways belongs to. This, and the anchor of a large family are enough to dispel any feeling of aimless drifting. Evie now works in a crèche in North Adelaide, where she travels by bus or tram from her Glenelg beach suburb (hence the title, Jetty Road).

Nearby lives her youngest sister, Paula, just about to turn forty, single mother of Bert, a sometime uni student, and little Rosie. Paula runs a small nursing home, Holmwood. The job, which is a large part of her life, steadies her. However chaotic her home life with the children, most mornings she manages to transform herself into the calm 
and collected matron who can deal with the trials and tribulations the Holmwood residents, many of them in various stages of dementia, present her with.

Kenneally successfully draws two sisters of very different temperaments. Evie has managed to put drugs and abusive men behind her, and pens the occasional chapter in her erotic novel set on a Greek island, which closely mirrors her own new relationship. Her life has equipped her well to be an agony aunt and, what is more, to be the trusted aunt of the next generation of Haggertys.

Paula lacks her sister's soft edges, her creative flights. To her, a nononsense person, administration and responsibility at work comes more easily than sensing her son's problems or relaxing with a new male friend, especially as the love for the father of her children has never quite abated.

There's much about children in the book: Paula's children, the children at the crèche Eve works at. There is almost too much about children. But this may just be part of the big Irish Catholic family syndrome. Kenneally has a good ear for the way young adults talk. But their predictable banter, studded with words that only their own close-knit group understands, can at times get a touch tedious, and exclude the reader rather than draw her in.

But this is a small quibble about a book which amazes with the joy to be found in small things. This can be an old jug found in an op shop, "a spotty yellow, jug, murky yellow, with white thumbprints. The squat curve, the sturdy handle, the milky glaze, were all perfect ...". In her facility for detailed description, Kenneally is reminiscent of another Adelaide writer, the late Barbara Hanrahan. But Kenneally's characters, unlike Hanrahan's, do not turn Adelaide into a gothic threat. Evie in particular is capable of a contentment and pleasure which is all the more amazing given that she, in her own words, has very little to show for her forty-five years. Yet all the same, she can be "incessantly amazed and pleased that the next minute, and the next, continued to present themselves."

Adelaide, too, is part of this pleasure: 
Humidity sat over the suburb, in the wake of the first rain of summer the day before, sweeping down from the Hills over the city, soothing jangled nerves and sending hordes of homeowners out when evening fell into their parched yards to look for signs of recovery. In the Hills, there'd likely be some pearly vapour in the morning - or perhaps it needed to get a bit colder ... that magical soft mist you could move through as through a thin sea, wrapped up in a few light layers so the outer one or two trapped the moisture, an Adelaide miracle.

Is there a plot to this novel? Not exactly. Everyday life is full enough to keep Paula and Evie busy, and the novel moves quickly from one scene to another. There are plenty of crises, in the immediate family or at work, get-togethers with other members of the family, flashbacks to the more horrid or happy moments of the past, and new men. There are no driving ambitions to fulfil except to get safely from one day to the next, and there is a distinct sense of gratitude when this can be achieved. In this, Keneally's spirited novel shows that life goes on, even after turning forty. 
Jennifer Harrison and Kate Waterhouse, eds.: Motherlode. Australian Women's Poetry, 1986-2008. Puncher \& Wattman, Glebe, N.S.W., 2009. 342 pp. ISBN 978192145016 7. By Miriam H. Auer, Universität Klagenfurt.

Occasionally gold can be found. Once in a while things precious emerge - even if we did not dig for them. Rarely do treasures born from empathic minds reveal themselves to us. The poetry anthology Motherlode, however, is such a rare lode of gold. Jennifer Harrison and Kate Waterhouse gave shape to the individual nuggets and thus enabled the readers to gain precious, poetic insights into the lives of Australian women via this book. This is exactly what turns the pages, and subsequently the reading experience, golden.

The 172 poems may be read both as individual works of art, each in its own right, and as a collective, emotional testimony of Australian women's destiny. Motherlode serves as a document of female identity that can be regarded as an attempt to resolve the eternal enigma of what it means to be a woman under usual, but also - more importantly - the unusual circumstances of inevitable feminine reconciliation with the twists of fate. In a nutshell, the book tells a story. Poem after poem a unique women's tale of love, spirituality, ignorance, prejudice, endurance, loss, failure, joy, dolour, strength and weakness unfolds. Miraculously, this one tale of twelve sections which function like chapters told by 125 authors with seemingly different lives unveils parallels. The terms 'mother-' and 'womanhood' qualify to be used synonymously in the framework of this anthology, because the voices of many women, motherly and aware of their lasting responsibilities even when they have not given birth to children yet, call out to our social conscience. While some do it silently and subtly, using metaphor to appeal also to those readers seeking escapism, others do it in a more pronounced manner. Emphatically they express their critical views, leaving no doubts about their determination to fight social inequities. Australian women writers as well as female poets of Indigenous ancestry comment on private and 
political issues. Their poetic brainchildren join hands in order to mimic the closed circle of life in which bitterness, tragedy and numb resignation have an incontestable right to exist alongside moments of elation and inner peace.

Despite the abundant incontestable qualities of the anthology, however, it needs to be mentioned that a few poems seem to have been included merely for the sake of quantitative completeness. This is not intended to imply that each and every poem has to be an enthusiastic celebration of word and metaphor, because in certain cases a minimalist style is the only gateway to perceptive efficiency. Nevertheless, single examples fail to emotionally touch the reader, which might be considered a flaw especially by recipients who believe a poem to be a nexus of emotion, intuition and impulse.

Motherlode's title clearly alludes to the main - i.e. mother - lode, known from underground mining. In the context of the volume, the reference to the major vein of Australian women's poetry is obvious. This mother lode could ensure an endless supply. Furthermore, an association with the homonym 'load' might occur because the burden of the female is the central issue all poems gravitate towards.

The attempt to raise public awareness and to encourage reconsideration of racial injustice in all its shapes and guises towards Australia's native population is manifest in Motherlode, too. Indigenous matters have a central function in the volume. Various examples of poetry against the forgetting could, in my opinion, be divided into six categories.

The first one deals with the Stolen Generations whose destiny was determined by humiliating assimilation policies like in Ruby Langford Ginibi's "The Gubberments" and Brenda Saunder's "Passionflower" $(185,187)$. "Lost Child" (208) by Jennifer A. Martiniello tells the story of mother and child, emblematic of Indigenous reality in the face of prejudice, who yield to the force of destiny. From the child's per- 
spective, a language rich in metaphor conducts a 'loss song' including the key-references to governmental 'playing God' by unjust marginalisation sealed with the false pretences of legality. The lines

crying I track

black ink ashes

down corridors of legislative

dispossession

the blood of evidence

dark upon my skin

and I follow you my dreaming

into another place

where I

will not lie down

functions as the main message. Summing up, it means that resistance and endurance collapse when resignation in the face of a deprivation of identity and cultural heritage sets in. Martiniello sensitively lends her poetic words to the silenced mourning of those sacrificed to inhuman policies intended to proclaim and institutionalise white men's superiority.

The toll the assimilation into a segregationist society took becomes the main focused in the second category. Attempts to disguise or to justify racist views, but also the phoniness of those pretending to be non-racist are in the centre of attention. Two-faced puppets on the government's strings are targeted in Elizabeth Hodgson's "I am in a room, it is day but the room is dark", and in Bobbi Skyes' "Black Woman" (186, 170-171). Hodgson's poem focuses on the status of Indigenous children as domestic servants in white households. The power executed by the masters, who forced them into linguistic, behaviouristic and cognitive assimilation processes is discussed. Distinctively, this poem makes use of native Australian cultural artefacts to intensify the overall effect. In this concluding extract, Indigenous bark paintings in the master's house symbolise his duplicitous mentality. "[...] Once I tried to touch the edge of a painting/ but his anger and his hands were quick./ I am learning how to please." The 
master knows little about the artefact's significance, but nonetheless insists on possessing them. In the same way, he 'owns' his Indigenous servant's identity by supressing her character traits. She is forced to adapt.

Stigmatisation by abuse, both sexual and as workforce, shapes the poems of the third category, which includes, for instance, Josephine Rowe's "She Tells Stories" and Judith Beveridge's "The Saffron Picker" (189, 292). In "She Tells Stories" Rowe demonstrates the crucial art of story-telling combined with sharp social criticism. Unbroken confidence in a change for the better allows the tragic heroine of the poem to bear even the hardest of lives.

A fourth dimension opens up with Oodgeroo Noonuccal's "Gooboora, the Silent Pool", Brenda Saunders' "Innargang", Lee Cataldi's "from kuukuu kardiya and the women who live on the ground", and Robyn Rowland's "Adhesion" ( 210, 230-231, 232-233, 250-251). Australia's native population was sacrificed to progress and driven off the land which had been given to the peoples by their Dreaming Ancestors. Western concepts of landownership blurred their visions of a future one with nature. Silenced and outnumbered, their search for means to survive is an ordeal.

A possible fifth category is conducive to (re-)familiarising the readers with Indigenous culture and spirituality. Ancestral protectors continue to play a role in Romaine Moreton's "mamillates and tresses" and Diane Fahey's "The Juniper Tree" (57-61, 206-207), whereas Daisy Utemorrah's "Our Mother Land" (27) melancholically glances back to an involuntarily abandoned unity of humans and the land. It concludes with the observation "The moon shines on the water, all is ended - and the dreamtime gone".

Poems on conflicts elsewhere in the world like Tatjana Lukic's "nothing else" on the war in former Yugoslavia and J S Harry's "Braid on 
Braid" $(272,277)$, focusing on civil violence in Baghdad are granted a platform. "Nothing else" can be read as emblematic of women's 'loads': superhuman strength is usually expected and thus they need to master the "art of pretending to be alright". No weakness must be shown. It is all about being able to say "no, i did not see anyone dying" albeit the truth may be: "yes, i saw the corpses floating along the river". To make others believe in one's own strength is a survival strategy.

Barbara Giles' engaging "Night Piece" on accidental infanticide (122) describes the numbness cast on a mother holding her dead baby, following a fatal reaction. The infanticide committed will never sink into oblivion and the mother will feel guilty forever. The final lines "[...] At the end of her tether, /she shakes it / silent. / Just like that, not meaning it"

seem rather indifferent, which only increases the effect of the raw tragedy. Life's demands sometimes consume sanity.

The lion's share of poems on birth concentrates on sudden infant death or the fate of the stillborn and their families. Melissa Ashley's "The Hospital for Dolls" or Claire Gaskin's "There is a word" (79-83, 95) can be read as documents of a search for emotional rehabilitation by uttering the ineffable. By contrast, Jan Owen's "Small" and Alison Croggon's "Nights" $(91,117-119)$ welcome the helpless newborn, although in these two poems the authorial voices admit that the world is a threat to innocence. Nameless but alive, if only for short a while, the baby in "Small" proves true the aphorism by George Bernard Shaw that "it is much darker when a star sets than it would be if it never shone". From the mother's perspective, the relationship between her and the vulnerable guest to this world is described in the following way: "So I have known you only/ as a chill in the blood,/ a rumour in the dark [...]". She verbalises her suspicion that "[...] in that quick flash you saw/ all the monstrous evil of 
this world". The memories of that chill and that rumour will always remain, though. They are immortal.

Having the ultimate aim of emotional equilibrium born from instances of contended restoration in mind, Jeri Kroll's "Water to Water (from A Coastal Grammar)" and Lisa Gorton's "Solitaire" (253-254, 255-256) potentially alleviate the imperative process of letting beloved ones go. Gorton's and Holt's texts recommend other ways of accepting time's limitedness. Similarly, a conciliatory undertone can be attributed to Kroll's poem on the consequences of Alzheimer's disease. The mother, as a patient often at a loss of words, familiarises her daughter with the fact that sometimes silence is alright:

My mother has taught me a lesson without a sound.

Words wash over her now.

It doesn't matter what she's floating in.

Even the word sea means nothing

because she becomes it.

Sometimes words are just words. It is the emotion that counts.

The embrace of the end as a pathway to a new beginning or a reentrance into the circle of life is longed for in Alison Croggon's "Where are the dark woods?", Margaret Scott's "Nocturne" and in an extract from Dorothy Hewett's "The Last Peninsula" (302, 303, 304307). The impression is created that, regardless of the dark veil of silence that advanced age and history's inalterability spread over the abilities to cherish life, acceptance holds the key to inner peace, even in contemplation of death. Hewett raises the question "is love a compass/ life an allegory?" and by doing so emphasises the importance of always choosing the path of love.

From birth into profanity, through years of cultural imprinting and partly indispensable pragmatism, to the overtly spiritualised moment of death and the uncertainty about what follows, the poems in 
Motherlode accompany the development of relationships between women and the world into a story of diverse experience. It is a story that concerns us all, no matter if we are female, male, young or old, because countless chapters are yet to be written. 
David Malouf: Ransom. New York: Pantheon, 2009. \$24.00. 224 pp. ISBN 978-0-307-37877-4. Reviewed by Nicholas Birns, Eugene Lang College, New York City, the New School.

Tn the title story of his most recent short story collection, Every 1 Move You Make, David Malouf describes the death of a trendy Sydney architect and designer, whose early death reveals the glory of his life and by inference the era of neoliberalism and bourgeois-bohemian boom it represented, as illusory. In Ransom, Malouf deals with a setting-the Trojan War-which literary tradition has endowed with an imperishable glory, but which on it sown terms raises the same questions about what is worthwhile in life as does the more contemporary story. Malouf's tale-short, lapidary, intense-focuses on the final scene of the Iliad, the brief reconciliation between the Greek hero, Achilles, and King Priam of Troy, the father of the man, Hector, who Achilles has killed in combat. This compassion across enemy lines, this caesura of mercy in the heat of combat, has long been considered the emotional peak of the epic. Malouf, by isolating the encounter, lyricizes it. Indeed, one of the formal achievements of Ransom is to reveal how the novel lyricizes the epic, a link that has tended to be sidleined by the anti-poetry tradition in theory as seen in Georg Lukács and Mikhail Bakhtin.

Longtime readers of Malouf, though, might notice certain moves Malouf does not make. Although the fraternal, even homosocial kinship of Achilles and Patroclus, whose death, partially caused by Achilles's own surliness and self-preoccupation, causes Achilles to kill Hector, the book does not revolve around the charged encounter of two men, as The Great World or The Conversations at Curlow Creek. The novel contains an ordinary, unhistorical figure, a humble carter briefly pressed in; Priam and Achilles are not peers; even had they not been on opposite sides, there would have been an asymmetry in the relationship, to service as Priam's herald, 
but the book is not told from his narrative perspective, 'from below', as has become popular in so many rewritings of classics, often with the kind of elegiac stance found in Malouf's first novel, Johnno. Instead, the carter's experienced is told from above, in a third-person narrative voice, which empathizes with him as it, to different degrees, does with Priam and Achilles. As one would expect from Malouf, there is a Flaubertian tightness about Ransom, but it is a tightness, a tautness, that affords a generous emotional perspective from every angle.

Malouf gives a bravura rendition of the Achilles so many readers of the Iliad have been fascinated by-impetuous, savage, but also strikingly introspective and compassionate. Part of his uncooperativeness in war is that he has the insight to put himself in the other person's shoes. With Priam, though, Malouf gives us a very different character from the magisterial monarch, the stoic front man we tend to picture. Using a relatively obscure mythographic fragment from much later on in antiquity than Homer, Malouf tells how Priam started out life as Podarces, one of the sons of King Laomedon of Troy, but saw his entire world wiped away when Heracles overthrow Troy and cosigned all its elements to slavery, Only the intervention of the young bo's sister, who pleads for his life at the last minute, saves him from an existence of ignominy and slavery. But after this searing ordeal, after this proximity to death, or to lifelong obscurity and humiliation, Podarces can never be the same person. Heracles renames him Priam, 'the price paid', and, even though he becomes king of Troy as he might have anyway he does so as a fundamentally different man, one who no matter what his rank and regality. This Priam is also a seer, gifted with the same second sight as his more erratically percipient daughter, Cassandra. In an astonishingly intimate conversation with his wife, Hecuba, after he conceives the scheme of asking Achilles for his son's remains, Priam speaks of 'the road my other self went down" (68) which he has lived "if only in a ghostly way". Much like in Maurice Blanchot's L'instant de ma mort, the sense of once having 
died, or known defeat and humiliation, if only for a moment, scars Priam for all his life of happiness and accomplishment, re-emerging in bulk after the death of his most famous son. Malouf gives us a vulnerable, three-dimensional Priam such as we have never seen.

The carter is Malouf's other innovation. Named, in his real life, Somax, he is asked by Priam to assume the name Idaeus, the name borne by all of Priam's heralds. This is one of several generic identities that stand between Priam, for all his insight and ordinary experience. He cannot tell the difference between most of his many sons, all his servants have the same name. The carter, whether he be called Somax or Idaeus, also, like Priam, has known tragedy. Indeed even more so, as all his sons have been killed. But, in contrast to the king, the carter is able to radically focus on specific relationships: to his beloved mule Beauty, to his only kin, his daughterin-law and granddaughter, who he cares for lovingly and altruistically. Indeed in a book about male bonding, about warriors and adversaries, fathers and sons, this regard and caring for the feminine is notable. Anyone who has encountered Homer in an introductory humanities course is told about the role of the similes and their role on the epic; to bring ordinary life into the landscape of war, to tell the everyday stories that war, in its permanent 'state of exception', would otherwise foreclose. Malouf conveys this sense, but goes further to convey a radiant sense of the ordinary as, for all its privations, sorrows, limitations, having a more radiant, capacious affective and moral expanse than the courts of Troy or the warrior camps of the Greeks. Particularly resonant is the carter's account of the griddlecakes his daughter-in-law has learned to cook: "A stack of little griddlecakes of a kind Priam had never seen before, of a golden yellow colour and about the size of a medallion" (118) of which the carter says:

... the lightness comes from the way the cook flips them over. Very near and quick you have to be. The daughter-in-law, she's a good girl, uses her fingers-it's a trick you have to learn-and if she happens to hurt them she pops them into her mouth quick smart, like this. (119). 
Priam is walled off from this kind of particularity. His status has kept him confined within the net of the general. Priam's self-control and gravitas prevent him from being hungry for the griddlecakes. But he recognizes they represent a dimension of experience on which he has missed out.

But the book is just as little about the bilateral relationship of Priam and the carter as it is about that between Achilles and Patroclus, or even Achilles and Priam. Readers of Malouf will have to suspend their trained tendency to see his books as about two people who are 'sharers', perhaps aspects of one self, in favor of a more fragile and multiple sense of the brevity of life and the countervailing sparks of momentary interpersonal encounters which provide meaning for, or 'ransom', the losses and ravages of a world that, unlike the contemporary Sydney of 'Every Move You Make', is rough even for the privileged. The appreciation of the ordinary as seen in the person of the carter is very Australian: he is a digger, a drover, a battler, an ordinary bloke, and what he retains as valuable amidst damage and ephemerality is the quantity to which the novel finally pledges its troth, as fascinated as it is by the narratives of the great and mighty.

While not drawing direct parallels to his own times-for instance, the book, though antiwar in its marrow, as any book about war has, at least on one level, to be, is not polemically antiwar-Malouf does not seek absolute anachronism here. This is the story of Troy for us, not for its own sake. Those later influences that lie between us and the material are admitted, starting with the later story of Priam's origin, and, as Malouf states in his note on sources-itself a prose poem, not the anxious litany of citationality it is in so many dreary postmodern rewrites-many of our most iconic images of the Trojan war, such as the story of the Trojan horse, come from Vergil, not Homer. Malouf describes Troy in ways that owe much to the subsequent Western tradition. When Priam is "obliged, in his role as 
king, to think of the king's sacred body" (43), this language is filtered through Shakespeare and even the twentieth-century political theory of Ernst Kantorowicz. Malouf speaks unnecessarily of "an ivory footstool from Punt" (73), Punt being the Egyptian name for what is now Somalia or Aden, a word probably not known to the Greeks until Herodotus. 'Unnecessarily', though, does not here mean 'gratuitously'-Malouf lets in the Egyptian term to show that other pasts, and our discoveries of them, mediate between us and Homer. Similarly, no modern reader can hear of Hecuba, or read Malouf's deliberately abstract and suggestive portrait of the final revenge of Achilles's son, Neoptolemus (Pyrrhus), without thinking of the roles these characters possess in the play-within-a-play scene in Hamlet. Indeed, Neoptolemus's sense of having botched the balance of roles-as warrior and man of compassion-his father had handed down to him shows that Hamlet might have been a role model for Pyrrhus, and not, as the Shakespeare character at one point feels, the other way around. Like the carter's mule, Beauty, who becomes an index for the book's values by the end, Malouf's sense of the past is hybrid, stitched together, both ordinary and great.

Malouf has always been able to create dramatic, vivid psychological situations, and he has always been able to write-no writer in English has been better on the sentence-to-sentence level in the past forty years. But sometimes his penchant for evocation rather than wholesale description has left the reader stranded among his buoyant phrasing.

Here, though, Malouf offers a more multidimensional fabric. He retells an old story in a way not only distinctive and original but incontestably moving. Ransom is replete, not with the consolation of sadness, but the more stark and difficult sadness of consolation. 
Richard Flanagan: Wanting. London: Atlantic Books, 2008, 252 pp. $£ 12.99$, ISBN 978184887072 7. Reviewed by Paula Kreiner, University of Klagenfurt

$\mathbf{R}$ ichard Flanagan's most recent book Wanting provides a stark contrast to the last book I reviewed for this journal. Like Bob Mainwaring's Escape to Van Diemen's Land Flanagen once again turns his attention to that remote penal colony. Unlike Mainwaring's unapologetically and uncritical convict-cum-pioneering success story, Flanagan's depiction of the colony of Van Dieman's Land, in particular the fate of its Aboriginal population is as distressing as it is uncomfortable.

In an author's note at the end of Wanting Flanagan refers to the "catastrophe of colonisation". It is this catastrophe that is depicted in the story of Mathinna, a young Tasmanian Aboriginal girl, adopted and subsequently abandoned by the governor of Tasmania, Sir John Franklin, the renowned polar explorer of the Northwest Passage and his childless wife, Lady Jane, as part of their great experiment of civilisation in the fledgling colony. This experiment is symbolically captured in a painting of the young but shoeless Mathinna wearing a favourite red dress given to her by Lady Jane. Mathinna's two dark feet are first painted over and later covered by the frame in a process reflecting the Franklins' attempts to eradicate and cover up her Aboriginality. In this task they fail for "the black child would not become white" (174). Recoiling from their failure in the colony and from Mathinna as the cause of it, they come to see her as representing their most public defeat in the colony and as responsible for Sir John's recall to England. In the ultimate irony, in a novel replete with irony, Mathinna, seeking to deaden the wretchedness of her subsequent life by alcohol, is strangled to death in a drunken brawl by a filthy red scarf that was once her beloved red dress. 
The Franklins' experiment leaves Mathinna floundering abused and abased between two cultures, at home in neither but left wanting to know where she belongs. Wanting also to have and hold onto those most precious of human feelings: love and human dignity. Mathinna's story reflects the brutal treatment of her people at the hands of the colonisers. Once the daughter of a proud tribal chieftain and then petted darling of the Franklins' her fall evokes the pity and horror of the fall of princes. As does the systematic destruction and debasement of Aboriginal Tasmanians and their ancient way of life. Those the colonisers can find are exterminated; those few that survive are rounded up like cattle and exiled to Flinders Island under the guardianship of George Augustus Robinson, their so-called 'Protector'. Guided by what he sees as the correct measure of rational science and Christian compassion he weans them off their diet of berries, native plants, shellfish and game providing them with flour, sugar and tea. Inexplicably, "still they provocatively went on dying" (215). Flanagan effectively captures the horror of the colonisers' socio-cultural ideas and moral values in seemingly bland statements such as the Protector's: "Other than that his black brethren kept dying almost daily, it had to be admitted the settlement was satisfactory in every way" (2). Conciseness of language is one of the pleasures of reading a Flanagan novel.

Running parallel to Mathinna's story in the novel, albeit later in time, is that of Charles Dickens, the most celebrated novelist and thespian of his age. Living in England after Sir John's recall as governor of the colony, Lady Jane's approach to Dickens connects the two stories: the brutal fate of Tasmania's Aboriginal people and the midlife crisis of one of history's great novelists. Seeking to defend her husband's reputation as a courageous and honourable explorer, Lady Jane asks Dickens's assistance in repudiating charges of cannibalism levelled at Sir John's ill-fated Arctic expedition. Dickens, faced with a bleak home environment following the loss of his youngest child, buries himself in writing a furious counterattack and in doing so becomes obsessed by the story of the lost Arctic explorers. He encourages and assists his friend Wilkie Collins, who dramatises the story in the amateur theatrical The Frozen Deep, which is subsequently performed to standing ovations for Dickens's starring role as the 
noble explorer Warden. In the course of auditioning professional actresses for the public performances, Dickens meets and falls desperately in love with the eighteen year old actress Ellen Terman. Flanagan's narrative moves easily between the different stories of the novel unified by the intertwined and seemingly inseparable themes of love, desire and despair. Love, or rather the cost of repressing love, is ultimately the central force of the novel. A multitude of different forms of that most abstract and difficult to define term 'love' compete with each other within the narrative jostling the characters around: attraction and compassion, lust and care, selfishness and selflessness, inclusion and exclusion. Dickens, who has just completed his novel Hard Times and who should be reaping the rewards of renown and wealth, feels that his soul is corroding and wants something more. He longs for the domestic happiness, contentment and love he writes about in his celebrated novels. He desires and is driven to distraction by Ellen Terman. Lady Jane desperately wants a child, to feel and give herself to a child's love, yet is terrified of giving in to this love. Instead she pushes Mathinna away and ultimately rejects her. She longs too for some passion in her marriage yet stoically makes do with trying to create something heroic out of her dull and ill-fated husband, who "gave no more appearance of an active intelligence than a welltended pumpkin" (53).

Sir John longs for the camaraderie and glory of his earlier expeditions to once more instil a sense of pride and purpose in his life. Ironically the white world of the arctic is "the only emptiness he knew greater than himself" (196). He is enchanted by and longs for the vitally alive Mathinna, but rapes and later abandons her in a squalid orphanage, thus precipitating her fall into prostitution and alcoholism that culminates in her squalid death at the age of seventeen. George Augustus Robinson, the Protector charged with removing the remaining Aboriginal people from Tasmania and overseeing them in exile on Finders Island, longs to introduce them to civilisation and the glory of God. He is angered by their failure to allow him to cure and civilise them and is haunted by the idea that their death and suffering might, just might, be related to him, to his actions and his beliefs. 
Flanagan's strength as a novelist is the force he brings to exposing the appalling colonial legacy in prose that borders on poetry. His narrative is both polemic and poignant. Satire sits along side of sensitivity to the very human limitations of his characters. The epic dimensions of the story are embedded with the individual. Flanagan's bitterly ironic depiction of the colonisers' attempt to bring the light of civilisation to Van Diemen's Land and its people has its place in the novel as does his sensitivity to Lady Jane's conflicting emotions towards Mathinna. Her inability to yield to maternal love and passion becomes a deadly form of cultural chauvinism. For Lady Jane it is this emotional control that marks the English out as different from the savages. Yet, Flanagan also provides us with glimpses of her desperate longing and loneliness beneath the façade.

Dickens too is caught between his yearning for love and his conviction that "the mark of wisdom and civilisation was the capacity to conquer desire, to deny it and crush it" (47). His longing for love propels him into increasingly frantic work on the play The Frozen Deep, which he sees as a metaphor for his own trapped and loveless existence. "For twenty years" he says at one point "had not his marriage been a Northwest Passage, mythical, unknowable, undiscoverable, an iced-up channel to love, always before him and yet through which no passageway was possible" (35). His obsessive on-stage representation of the character Warden provides him with a venue to give into and exult in his love for Ellen Ternan. In the role of Warden, he discovers he no longer wants to deny his wanting.

Ironically enough this insight takes place while on stage, while acting as opposed to living the ups and downs and complexities of real life. It propels him into the arms of Ellen but fails to provide him with an insight into the causes of the poor state of his own marriage. He sees only his wife Catherine as dull, lethargic and embittered. As a woman who views pregnancy after pregnancy as a cause for melancholy as opposed to jubilation. And yet she is hurt by his retreating from her emotionally and is worn out by multiple childbirths, suffering from back ache and a weakened bladder as 
well as the recent loss of their baby girl Dora. Her tragedy is to be married to a literary great capable of infusing the character Warden in the play with selfless and heroic love but incapable of viewing his own wife compassionately. His tragedy is that he fails to understand he is play-acting and that escaping from the difficulties of his marriage has not in any way resolved those difficulties or addressed the cause of his wanting something more in life.

Wanting is a novel about the sad and tragic consequences of denying or being denied love. Flanagan moves from the failed and selfish wanting of the Franklins to Dickens, who believes he has found fulfilment to his wanting in the arms of Ellen. Nonetheless, at the end of the novel both Lady Jane and Dickens remain imprisoned emotionally. Neither her selfish stoicism nor his flight into play acting appears to offer a real and permanent solution to their wanting. And pretty and spirited Mathinna, who so enchanted Lady Jane and Sir John? Towards the end of the novel Flanagan writes of her that "The dance had left the dancer" (196). This is surely as sad and as evocative a description of the 'catastrophe of colonisation' as any. 
Samson and Delilah, Australia, 2009. Directed by Warwick Thornton. Starring: Marissa Gibson, Rowan MacNamara, Mitjili Gibson, Scott Thornton. Screenbook: Warwick Thornton. Producer: Kath Shelper. Reviewed by Heide Fruth-Sachs

This film hit a nerve in Australia. It contributed greatly to intense and controversial - public discussions about the problems in Aboriginal settlements in the remote outback and the circumstances and politics that intensified these problems.

Apart from its social and political impact Samson and Delilah is a great film. It draws the onlooker into the scene through close-ups which often give you the feeling that you are sitting beside or in front of the actors, as if you were part of the scene. Warwick Thornton made the film with a handheld camera. Samson and Delilah won the Camera d'Or at the Cannes Film festival 2009. Thornton is an indigenous artist, and so are all his main protagonists. Like Thornton himself, they are at home in the area around Alice Springs. Apart from the actress who played Nana, the grandmother, all others were amateurs in their first film roles.

Samson and Delilah is not easy to digest. You leave the cinema distressed because of all the sadness and violence. The cause of the violence is uprootedness and boredom. The young couple in the centre of the story are teenagers, 15 or 16 years old. There are no parents around. God knows where they are, perhaps in jail. Or have they abandoned their children? The girl lives with her grandmother. They have a small income through their dot paintings which are from time to time collected by a white dealer who supplies them with the painting material. One suspects immediately that the dealer gets a lot more money from the paintings than the artists. In a later scene the girl, after having run away with Samson, tries to sell her beautiful picture to tourists in the mall in Alice Springs and to an upmarket gallery. In vain. The marketing of Aboriginal art is done by Whitefellas. 
Samson, the male protagonist, lives in the house of his older brother. His possessions are an old foam mattress, some dirty blankets, old jeans, a shirt, his radio with some music cassettes and a can for petrol-sniffing. He has nothing to do all day except hang around, following Delilah, who at first rejects him. During the whole film he speaks only once. A friendly hobo who shares his meagre food with the youngsters repeatedly asks for his name. Finally, in a sickly hoarse voice, he says "Samson".

Delilah is cruelly beaten by relatives after her grandmother's death. She is wrongly accused of having neglected the old woman. The relatives want to take over the grandmother's possessions. Samson tries to play the guitar in his brother's rock band. He takes the instrument to try it out, and it ends in a struggle between the two. Samson hits his older brother with a stick, but is brutally beaten in retaliation. The film shows shocking cruelty to fellow human beings both inside and outside the native community. In town Delilah is kidnapped by three young white men, probably raped and once again beaten up. Samson in his petrol-sniffing stupor does not even realise her disappearance. Mourning her he cuts his hair with a knife - as Delilah did after the death of her grandmother. So far this rite of mourning is the only reference to the biblical story from which the names of the protagonists are taken.

Samson and Delilah is a love story, but the boy and the girl never speak to one another. They communicate only through signs and silences. The only one who expresses himself in words and song is the friendly native drunkard under the bridge. He warns Samson to stop his petrol sniffing: "It will muck up your brain".

This is what happens in the end. Delilah returns to find Samson a hopeless drug victim. She had been run down by a car, taken to a hospital and patched up again. Her broken leg is in a splint. Social service people help her to cart Samson away in a car which is then given to her (through the insurance company? As compensation?) to start a new life. She does it by finding an abandoned shack on an old cattle station; she cleans it, stacks it with tinned food, succeeds in getting the windmill to work and fills the water trough. Samson 
has to be washed and fed. At the beginning of the film the grandmother sat in a wheelchair, now young Samson is the patient. Delilah, limping, takes a rifle, goes into the wilderness and comes back a successful hunter, a roo over her shoulder. In an earlier scene Samson did the hunting and walked proudly through the camp with his prey.

While Samson sits in the wheelchair clutching his radio, Delilah begins to do her dot paintings again. A circle is closed.

We are left with an uneasy feeling. What are the prospects of the couple? Is there a chance that Samson can be cured? Will they survive the loneliness of the outback, shunned by the community? Delilah is a strong girl, physically and mentally, but is she strong enough to master such a hard life? However, it is certainly better than sleeping rough under a road bridge. She takes her and Samson's lives into her own hands, caring for him and working.

Some journalists have criticized the ending of the film as too romantic. "Samson and Delilah continues the myth of escape, puts off the day when Samson and Delilah must be schooled in the way of living in the real world, far from the romance of the film world" writes Gary Johns in The Australian (June 4, 2009). Others praised the film as "heart bruising", but "joyous".

"Joyous" is perhaps not the right word, but glimpses of hope and humanity can be seen in spite of the tragedy. We are touched by the unobtrusive understanding of the drunken clochard, who shares his food and the warmth of his fire with strangers and who tries to cheer the frightened children up without expecting something for himself. The outcast helps other outcasts. Not so the priest, who does not ask young Delilah what was the matter with her when she walked slowly through his church with hollow cheeks, a bruised face and dirty clothes. I do not think (as does Gary Johns in the abovementioned review does) that Thornton in this scene accuses the Christian priest or missionaries in general of cold-heartednes. He only points out that their role as helpers and developers in the Australian outback has come to an end. Delilah does not expect help from the priest, she does not even look at him, she only looks at a big 
cross on the wall, then leaves and shuts the door softly, while the priest passively follows her with his eyes.

Wherein lies the beauty of the film? It is in the young faces of both the protagonists, it is in the colourful dot paintings, it is in Samson's dance for Delilah when he succeeds in drawing her attention to his sensual dance, while his shadow dances with him on the wall behind the open fire, until his brother pulls the plug of the radio. Certainly, there is more distress than beauty, but beauty is there too.

The film is also a documentary. The houses in the community are built of soulless concrete. All the buildings are worn down and dirty, the walls covered with graffiti. The only shop has little to offer. Waiting in front of the health centre, a trailer home, you had better sit on the back of the chairs because if you do not, the ants will get you. The public telephone in front of the health-centre rings and rings and nobody bothers to answer. Only once, when Samson and Delilah are back, he with his damaged brain in a wheelchair, she still limping, does she pick up the phone. There is no-one at the other end.

Shortly after this film Peter Sutton's book The Politics of Suffering Indigenous Australia and the end of the liberal consensus appeared (MUP, 2009, 268 pp. ISBN 978-0-522-85636-1). Sutton, a well known anthropologist who spent decades in the northern territories, demonstrates that the liberal politics of the Australian Government in the last 30 years have been a disaster. After the missions lost their power and influence, Aboriginal societies in the outback began to decline in spite of the huge amount of money spent on them. Welfare was a one-sided affair and encouraged passivity. A wrong understanding of "freedom" allowed alcohol, drugs and pornography a takeover in many Aboriginal communities. The consequences were a brutal degradation of behaviour and norms. If crimes were committed, Australian law was often not applied, the excuse being a protection of old traditions - for example punishment by spearing. However, the old culture of the First Australian Nations was no longer alive and could not be restored. Official indulgence for doubtful Aboriginal law practices, corruption and egotistical clan loyalties led 
to grave injustices in many outback areas. Women and children suffered and still suffer from a male dominated, often violent group order. The young had and have too few prospects of a good future. There always was and still is a high rate of unemployment. Separated from the mainstream culture in Australia the ghettos in the outback have become places of stagnation and hopelessness.

Self-government has been a failure in too many outback communities and black Australians must be blamed for this. However, the idea of political correctness and the resulting principle of nonintervention are concepts which were born in white brains; the idea of liberalism or democracy did not exist in the traditions of the indigenous peoples - these have been forced onto the Blacks. The money for the unsuccessful outback projects has always come from the white Government; therefore the Government must be considered equally guilty of the resulting tragedy. Peter Sutton asks: was it not irresponsible on the Government's part, toward the Australian nation as a whole, to throw money into a bottomless pit, with no real supervision as to how it was being spent?

Dating from the Intervention of 2007, problems are now being discussed that for too long were swept under a liberal carpet of selfdeception. Naturally this development has a long and complicated history, the impetus of which, however, has always come from white politicians, who invariably decided what was best for the Aborigines. W.E.H. Stanner, the famous Australian anthropologist (1905-1981) who was Advisor to several governments in the 1960s and early 70s, was aware that many Aborigines preferred to live like Whites. Nevertheless he espoused the view that they could only be truly happy in their native culture.

The culture clash between black and white Australians is still going on. It will take time to adjust it. Jenny Macklin, the new Minister for Aboriginal affairs, is endeavouring to solve these problems by listening to men like Peter Sutton and Noel Pearson. Both campaign for a much more active participation of indigenous people in changing their situation for the better. Mission-educated Noel Pearson, today a well known indigenous politician, is the man who might be able to 
show how to tackle these problems. He confronts his native people and white Australians with uncomfortable truths, but he also points a way towards a better future. In a recent speech he said: "We do not want a sit-down culture, we want a hands-up culture."

In her quiet and persistent way Warwick Thornton's Delilah has put her hand up. 
Philip Mead: Networked Language: Culture and History in Australian Poetry. Australian Scholarly Publishing (North Melbourne) 2008. 540 pp. ISBN 978-1-74097-197-3. By Andrew Taylor, Edith Cowan University.

One afternoon in October 1943 two young men sat down in Victoria Barracks in Melbourne and created a poet. Both went on to become published poets in their own right, but on that day neither of them had published a book. Knowing what the tedium of army life can be like, I can imagine that they thought that what they were planning would be fun, although later they denied this was a motive. Their main aim was to show up the pretentiousness and meaningless nonsense (in their eyes) that a very bright young man from Adelaide, Max Harris, was printing in his new journal, Angry Penguins.

To understand the motives of those two young men, one needs some idea of the conservatism of Australian society and its literary culture in the first half of the last century. There were some writers whose work transcended it. Most notably there was the novelist Christina Stead, whose first novels were published in the 1930s, but whose creative life was lived mostly outside Australia. On a more local level, Christopher Brennan, a brilliant scholar and poet, and correspondent with Mallarme, wrote a Symboliste-inspired and Germanicly heroic but doom-laden poetry at the turn of the nineteenth into the twentieth century. But after his alcohol-hastened death there were no followers. At about the same time a near-blind farm worker John Shaw Nielson (SP) wrote some of the most delicate, limpid lyrics regarding the relation of the human world to nature that one could imagine. He deserves to be recognised today as one of the great practitioners, anywhere, of what we might now call the poetic articulation of our place in the ecology.

Brennan was a scholar of German literature and Professor at the University of Sydney until his lifestyle led to his (unthinkable by today's standards) dismissal. He knew contemporary European writing intimately, but his formative knowledge of it stopped before the First World War. Nielson knew little of what was happening outside Australia due both to the inaccessibility of books and his poor eyesight. 
Still, recent research has indicated that he was no innocent, unlettered genius, flourishing in the waste. My point though is that neither of them was aware, so far as one can tell, of that massive shift of the imaginative ground that we now call Modernism.

And in Australia such ignorance persisted for the next forty years. In poetry there was one exception, Kenneth Slessor, whose path to Modernism's vision of a random and meaningless world that frustrated our hopes for significance and coherence was individual, slow and difficult. By the end of the 1940s Slessor had stopped writing poetry, though he lived on until 1971.

One can only speculate on why Australia did not participate in the Modernism that swept Europe and the USA. After all, Australia was part of the Anglophone world. But Australia's publishing and book distribution was closely tied to Britain's, and not the USA, and this might have been a factor. Furthermore, eighteenth and nineteenth century British writing had largely provided the models and influences for Australia. Another reason might be the Australian nationalism of the decades after Federation in 1901. The fragmented and angst-ridden literature produced in Europe and elsewhere did not coincide with Australia's image of a young country riding triumphant towards a proud nationhood on the sheep's back. Whatever the reasons, with the exception of Slessor there was little manifestation of Modernism in the poetry published in Australia until Max Marris and his friends decided to publish their Angry Penguins.

Angry Penguins was a short-lived journal established in Adelaide during the war years when paper was in short supply. Edited by Harris and with support from people in Melbourne - most notably the arts patron and lawyer John Reed and the painter Sydney Nolan, who later became Australia's most internationally recognised artist it was determinedly avant-garde. Surrealism was welcomed, as was anything that confronted the plodding realism of so much Australian writing - fiction especially - of the time. It was this brash embrace of the avant garde that prompted James McAuley and Harold Stewart that fateful afternoon in Victoria Barracks to invent their poet, Ern Malley, and to have his equally fictitious sister send Ern's hand- 
ful of 'posthumous' poems to Harris, who eventually published them in a special edition of his magazine in 1944.

The poems were a collage of phrases extracted at random from a small number of books that happened to be lying around, and were deliberately written to be meaningless. However the hoax took a serious turn when the police took action against Harris for publishing obscene material. In 1944, with the war in the Pacific raging, one would have thought there were more dangerous things to defend the Australian people against than a scattering of possibly suggestive certainly not explicitly sexual - phrases in a journal with almost no circulation. But Harris, at that time a twenty three year old undergraduate at the University of Adelaide, took the stand and after days of detailed and belligerent cross examination was found guilty of publishing obscene material and fined five Pounds, with costs of twenty one Pounds and eleven Shillings awarded against him.

The Ern Malley affair, as it is known today, is central to Philip Mead's recent book, Networked Language, in which it is the subject of the largest essay, for several reasons. Mead's aim is explicitly not to write a history of Australian poetry, and if I have dwelt on the Ern Malley story, it is because it tells us a lot about the social and literary network within which Australian poetry developed. Its conservatism, obviously, but along with that an attitude towards sexuality - a fear of promiscuity - that finds expression also in an attitude towards language. As Mead well argues, poetic language challenges conventions, breaks rules, defies expectations, provokes, seduces, and is voracious in its choice of bedfellows. It is, in fact, promiscuous. This is particularly true of the language of Modernism, although the supreme example of such a writer in English is Shakespeare (whose problematic play, Pericles, Prince of Tyre, was one of McAuley's and Stewart's sources.). "What was on trial" significantly for obscenity "... was poetry itself" (110), Mead argues.

And being what it is, such language challenges the reader to make sense of it. During his days in court, Harris manfully defends his decision to publish the poems by an extended attempt at construing them into sense. Mead gives us extensive transcripted court material 
not previous published, in which Harris, although acknowledging by now that the hoax material was intended to be meaningless, reads it, against the grain and against his own inclination, for meaning with considerable agility and tenacity. And towards the end of the chapter, Mead himself tackles several more of the Ern Malley poems, sensitively and with considerable erudition reading them in the context of Shakespeare's play. Unlike Harris, though, Mead reads the poems as a liberating and transgressive (sexually promiscuous?) mishmash of associations, echoes and allusions, as an opening up of reading opportunities rather than a fining down to something like a determinate meaning. In fact, Mead argues that the Ern Malley hoax was "the beginning of literary postmodernity in Australia" (88).

Another point Mead discusses at length is the question of hoaxes and fakes. Australia has had its fair share of literary hoaxes, but the underlying point he makes is that in a sense all language is a hoax or, if you prefer, a proxy for something that is not there. This is Derrida's point of course, regarding the deferral of meaning, or Différance, though Derrida gets only brief mention in Networked Language. By being an imposter (i.e. not the real thing but something masquerading as it) language gives us both the illusion and a measure of control over the non-linguistic world in which we live. By our complicity with it we too are imposters - i.e. we impose on the world, and we adopt a posture towards it. The network that Mead focuses on, then, is not simply the social and historical context within which language acts (though this is certainly not ignored) but rather something like the World Wide Web, virtual rather than real, dynamic and at any point almost evanescent, rather than static or moving with the ponderous pace of history. As Mead writes in his Introduction, "Poetry is networked language in the sense that it is designed to generate meanings through structure and connection. At the same time, because it is made of language, it maintains a kind of non-contiguity with the world... that nevertheless it always refers to and is always constituted in relation to" (4).

Another illusory language is cinema, brief two-dimensional flashes of light that seem to give us something so close to the real world that 
we willingly give ourselves to Coleridge's temporary suspension of disbelief in its substantiality. Mead deals with this in an excellent opening chapter on Kenneth Slessor who, for many years, was Sydney's leading movie critic. I have argued elsewhere that Slessor became Australia's first Modernist poet, and certainly one of its finest, even though he stopped writing serious poetry in the mid 1940s. Mead too sees him as Modernist. In the 1920 s and '30s, he argues, "cinematism was a response to new forms of experience inaugurated by modernity" and poetry, like the movies, seemed able to rescue moments from the flux of time. Such an impossible hope is central of Slessor's greatest poem, the elegy "Five Bells" (85). But again poetry, being language, is not life - any more than cinema is - no matter how life-like it is. Loss and profound sadness, even a sense of bewilderment, remain the dominant note in Slessor's late poems. It is, in fact, their acknowledgement of the limitations of language and poetry itself that partly accounts for their greatness. Again one thinks of Coleridge, whose lament that he has lost "the shaping spirit of Imagination" paradoxically informs one of the great Romantic poems in English.

In his Introduction Mead claims that "the discourse on poetry in Australia has found it difficult to move beyond a formalist, basically New Critical, paradigm." Also, that the old institution of literary studies in Australia privileged "a certain nationalistic cultural agenda rather than internationally networked and theoretically driven explorations of poetic writing and culture" (10). This was undoubtedly true some decades ago when the Association for the Study of Australian Literature was established in an effort to legitimise the study of Australian literature (including poetry) in universities. Whether it is as true today as Mead seems to imply is questionable. Feminism, queer theory, post-colonialism and more recently ecocriticism have surely rendered the old nationalistic exercise obsolete. The almost obsessive search for an 'Australian identity' that characterised the nineteen seventies and eighties has long ago foundered like Pharoah's chariots in the ocean of internal diversity that is modern multicultural Australia. John Howard, who as Prime Minister tried to resuscitate the lost art of nationalism (to paraphrase Ezra Pound), was voted 
resoundingly out of office and even lost his own seat in Australia's last election. Mead spends little time examining these changes. And there is no mention, surprisingly, of Paul Kane's excellent study of Australian poetry in its relation to Romanticism and its absence. Instead, he has marshalled an impressive range of reference, mostly from outside Australia, in support of his analysis of poetry as networked language.

The question of nationalism comes up, however, in his chapter on one of the perpetrators of the Ern Malley hoax, James McAuley and his long poem Captain Quiros, which he describes as McAuley's attempt at national myth-making. This narrative poem about the sixteenth century Portugese navigator is seen by Mead as "an influential but failed attempt at mythopoesis" (25). It was claimed at one stage that Quiros set foot on the East coast of Australia long before Captain Cook, although this has since been effectively disproved. Perhaps McAuley's answer to Kenneth Slessor's Captain Cook in the latter's suite "Five Visions of Captain Cook", the navigator Quiros is a kind of spiritual epic voyager whose heroism might constitute something of a founding myth of Australia. But despite its ambition and length, Captain Quiros is not McAuley's finest poetry. Few people today would read it with anything other than a sense of duty, and Mead, in his heroic engagement with the poem, makes no great claims for it as a poetic achievement. His interest is in what the poem was trying to do, and how it tried to do it, and the social, historical and poetic contexts or networks, specifically a Voyager tradition in Australian poetry, with which it engaged and still engages. His conclusion is that the Quiros story remains a "marginal but strangely persistent presence in the Australian imaginary" (267).

McAuley's contemporary, Judith Wright, receives a much more positive appraisal. Wright was not only a poet but also a public intellectual, an outspoken advocate of what today we would call rather glibly ecological issues. She was also a clear sighted critic of Australia's white colonial past, in which her own family had been deeply implicated. Mead rightly claims that she is an uncomfortable and unsettling presence, "canonical and radical, mainstream and oppositional, 
iconic and alternative", the kind of poet that Australia can only benefit from (269). One of her early books was titled The Two Fires, and Wright's oeuvre (which comprises much more than poetry) displays a challenging duality as unsettling as language itself. On a personal note, when I was introduced to her poetry while still a schoolboy, this quality inspired me to try to write poetry myself. She would have been a thorn in the side of the conservative John Howard, who deplored what was called "the black armband school of history", i.e. a history that reminded us that the success of white colonisation came at a massive price paid not only by the continent's original inhabitants but also by its ecology. Mead impressively analyses her career and her writing in terms of her inability to be at home - both personally and linguistically - within Australian culture and history, her unsettling "homelessness" which is "'the essential', inescapable condition of modern humanity - metaphysically, linguistically, socially and nationally" (337).

Mead's final two chapters continue this focus on the marginal. I do not mean that Wright is marginal to the story of Australian poetry and social consciousness, but that she dwelt on the margins, on the littoral, on that uncomfortable space where antinomies encounter each other. (The property where she spent her final years was called, significantly, "Edge".) The same can be said of John Tranter, subject of the fifth chapter, and the Aboriginal poet Lionel Fogarty and the Greek/Australian who goes by the defiantly Greek name $\pi$.o.

The essay on Tranter explores what happens when he uses computer-generated text (Mead describes the process in some detail) as a basis for his own poems. The program, called Break Down, analyses a prior text then spits out nonsense, which Tranter then works on to produce tantalising and ultimately unresolvable narratives. In a nice symmetry, one is reminded of the young Max Harris in that Adelaide law court so long ago, bravely construing into meaning the deliberately 'meaningless' verbiage of the fictive Ern Malley. Of course the results are different, but each in his own way is engaged in what Eliot called "the intolerable wrestle with words and meanings." Tranter seems to be mounting a bemusing assault on the lyric I, so much 
the target of poetics in the last few decades. Yet contradictorily, by his own admission, his finished narratives are the product of sustained and conscious work, each one passing through maybe a dozen drafts before reaching their incomplete completion. Why are they of any interest to us? Like much of John Ashberry's poetry, and like the paintings of the Armenian-American Abstract Expressionist Arshile Gorky, they "tease us out of thought, as doth Eternity" (to quote Keats.) Meaning, that elusive and seductive object of our desire, is always a step ahead of us, always slipping around the corner and donning a new face before we can grasp it. Because, as Mead rightly says, "it's actually impossible to escape the humanness of language, even in its anonymous, arbitrary enunciations" (392).

That humanness is brought to centre stage in his discussion of the Aboriginal poet Lionel Fogarty and the Greek-Australian $\pi$.o. Both work at the margins of what Mead calls a bit unquestioningly the main stream of contemporary Australian poetry. Fogarty has forged a distinctive and transgressive English that challenges the assumptions underlying the dominant paradigm of Australian English and its colonialist inheritance. $\pi$.o. does a similar thing by exploring innersuburban Fitzroy with its immigrant cafes and heteroglossic locales that have largely been ignored in more 'mainstream' Australian poetry. Mead sees the work of these poets as revealing how the language of contemporary Australia with its colonial history is "maintained at... the cost of interdicting... the self- and cultural formation of Aboriginal and migrant Australians" (421). And any other nonmainstream element in Australian culture, for that matter.

Although the poets in Networked Language are discussed in chronological order, this book is not a systematic study of Australian poetry, and certainly not a history of it, but six extended essays on aspects of language and culture treated in relation to relevant examples of Australian poetry or poets. They are spacious essays, not hurrying to make their point, sometimes healthily repetitive, with an extraordinarily wide range of reference. They can bear serious rereading, as Mead's arguments are complex, wide-ranging and erudite. My one complaint is that the book lacks a bibliography. Given 
the extraordinary number of works cited, it is almost impossible to track individual works down except by constant cross-referencing in the Index. But that is a minor flaw in what is undoubtedly a landmark contribution to Australian literary studies. 


\section{Clemens W.A. Fritz: From English in Australia to Australi-} an English. Frankfurt am Main, 2007. Xii+297 pp. ISBN: 9783-631-56702-9. Price: from $€ 53.10$ - $€ 56.80$. Reviewed by Jitka Vlčkovà, University of Brno.

The rise of new fields in linguistics, such as sociolinguistics, psycholinguistics and computational linguistics in the second half of the twentieth century has opened the way to a deeper understanding of language and its functions in social communities. The possibilities presented by a wide spectrum of linguistic reseach triggered interest in language varieties, with English being of prime concern. In his book, From English in Australia to Australian English, Clemens W.A. Fritz demonstrates how language use adapts to current environmental and social conditions, and that the process of language adaptation may sometimes bring along changes in semantics and, consequently, in communicative practices.

C.W.A. Fritz offers the reader a broad view of the circumstances that led imported English to Australia in the $18^{\text {th }}$ century to develop into a distinct variety recognized as Australian English in the $20^{\text {th }}$ century. The book comprises three major parts, entitled The Story of Australian English, A Corpus of OZ Early English (COOEE) and Studies of COOEE. Each part is a complex unit providing background information for the part which is to follow. Fritz gives an intimate account of events, people, relationships and conditions in four distinctive periods of white colonization and settlement. These four periods are later referred to in the discussions on the stages of linguistic developments in Australia. The first period, 1788-1825, which was marked by the struggle for survival in an alien environment, was characterized by the absence of a strong middle class. Convicts were the most numerous group in the colony. The governors were very much concerned with children "who should not follow the wicked ways of their convict parents" (16), and the solution was sought in education. Unlike Europeans, Australians did not hold prejudices and valued a person's achievements more than their origin. This attitude 
gave rise to egalitarianism, which became "Australia's distinguishing characteristic" (23).

Fritz points out the erroneous views of earlier scholars who thought that convicts spoke a uniform and clearly distinct dialect. The fact is that the settlers, both convicts and officers, were a heterogenous society who came from different parts of Britain and Ireland. They widely differed in their dialects and sociolects. Everyday contact between speakers and the consequent dialect mixing resulted in a new koiné - proto-Broad ${ }^{1}$, at that time still very different from any present-day variety. As the largest group of immigrants to Australia came from the south-east of England, their phonology was most influential. Americans, who have always been a small minority in Australia, had very little linguistic influence.

The second period, 1826-1850, witnessed the establishment of new colonies beyond NSW. The population grew not only due to convict transports at the beginning of the period but also thanks to the encouragement of free (assisted) immigration, often from Scotland and Ireland. Scottish and Irish language varieties, however, did not exert much influence. The overall view is that proto-Broad was southern-English in character.

The next period, referred to as the "years of growth" (1851-1875) is marked by the discovery of gold which attracted many immigrants from abroad, and which also caused massive internal migrations. Victoria, Queensland and Tasmania had been officially established by then. Literacy was enhanced by the introduction of compulsory education. The lifting of Stamp Duty and a generally high level of literacy enabled newspapers to be published in Australia.

\footnotetext{
${ }^{1}$ Wikipedia: In linguistics, a koiné language (common language in Greek) is a standard language or dialect, that has arisen as a result of contact between two mutually intelligible varieties (dialects) of the same language. Since the speakers understand one another from before the advent of the koiné, the koineization process is not as rapid as pidginization and creoliza-

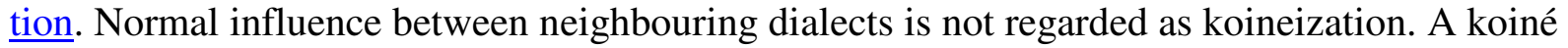
variety emerges as a new spoken variety in addition to the originating dialects; it does not change any existing dialect. This separates koineization from normal evolution of dialects.
} 
Linguistically, the most frequent features of the accents spoken by immigrants combined with the existing proto-Broad gave birth to a new koiné, koiné-General, which later developed into proto-General.

The last period covered in the book is the period of "Nativization and Urbanization" (1876-1900), culminating in the foundation of the Commonwealth of Australia. In the fourth period, the importance and recognition of education was higher than before. Higher education institutions used mostly British teaching materials, British views and standards were promoted, including RP in speech. Industrialization brought along social stratification; the upper classes favoured British standards and RP. Their attitude was fostered by admiration for the new British immigrants establishing themselves successfully in important positions in Australia. The contacts between the two groups resulted linguistically in a new koiné, koiné-Cultivated. It was the young generation then who nativized koiné-Cultivated and consequently made it proto-Cultivated. By 1900 English in Australia was markedly different from other varieties of English but it took Australians several decades to accept it as a distinctive variety of English in its own right.

The second part of the book, which occupies only seventeen pages in the book, is dedicated to the Corpus of OZ Early English. It describes the procedures used to create the corpus. The corpus, which was used in the analyses presented in the next part of the book, contains about two million words. The data came from 100 different sources, such as letters, newspaper reports, legal texts and historical texts published on the internet, to name just a few.

The third part of the book is divided into three major sections. The first one presents the lexis and its enrichment - related to the environment and living conditions the settlers faced: the contact with indigenous peoples and the until then unknown fauna and flora, convicts and bushrangers, the bush, the discovery of gold and life in the city.The last subchapter in this section is concerned with the influence of America, since the contacts were there almost from the very beginning of Australia's establishment as a penal colony (156). In the discussions, the lexical items are introduced by a short note 
on the surroundings, in which they were used whether social or natural. In addition to the data and examples from COOEE, the reader is informed about findings of other scholars.

The second section deals with aspects of morphology. The author starts with features of derivational morphology which are typical of early as well as present-day Australian English. The suffixes $<i e\rangle \mid\langle y\rangle$ (as in Richie) vs. $\langle 0\rangle$ (Richo), <*roo> (as in kangaroo) and <ee $>$ (corroborree or addressee) are introduced as specific features of Australian English word formation. The origin, usage and meaning of these suffixes are explained and the readers are provided with several examples from COOEE. Reduplication and compounding are then dealt with. Both seem to be highly influenced by Aboriginal languages. While reduplication became more frequent thanks to Aboriginal models, early compounds with native and bush labelling indigenous designata receded in favour of Aboriginal terms. Thus early native dog was replaced by dingo.

In the part entitled "Inflectional morphology" Fritz focuses on nonstandard verb inflections (namely present tense $-s$ and was/were levelling) as well as on past tense and past participle formation. He not only highlights specific properties of AusE, but also shows them in context of the contemporary varieties of English world-wide.

The third section deals with word classes and syntax. Pronouns are the first word class treated in this subchapter. The usage of thou, thee, thine, ye, yea, yee, yous and you all is explained and contexts, in which these marginal pronouns occurred, are specified. According to corpus data, IrE is responsible for the expansion of some of these pronouns, especially plural forms of you (yous, yee). Unusual sentence functions of conjunctions (and prepositions) but, and and as are revealed and commented on. While adverbial but could not be found in COOEE at all and subordinating and occurred only to some extent, relative as "was a frequent feature of early English in Australia, enjoying a healthy life in the period covered" (214).

Syntactic aspects (verbal concord with collective nouns, the progressive and the mandative subjunctive) are dealt with in great detail. Firstly, the situation in present-day varieties of English is outlined. 
Secondly, findings from COOEE are summed up and, finally, $19^{\text {th }}$ and $20^{\text {th }}$-century Englishes are compared. Unlike some of the previous subchapters, these thorough and informative analyses are clearly structured and it is not difficult to follow them. The development of AusE as a colonial variety is shown in comparison with the language of the mother country, Great Britain, as well as other colonies. Thus the reader discovers that as far as singular concord is concerned, the colonies were more advanced than Britain. The progressive is still becoming more frequent in present-day English, especially in AusE and NZE. And while should is the most common modal in subjunctive in BrE, there are more possible choices in AusE.

Besides statistical data, Fritz provides his reader with a great deal of sociolinguistic information. When analysing examples from the corpora, he takes into consideration gender, nationality and social status of their authors and types of texts in which they occurred. This enabled conclusions to be made not only on general usage, but also, for example, that men were less likely to use the progressive aspect than women in $19^{\text {th }}$-century AusE.

All parts of the book are amply complemented with examples and tables which provide the reader with more details on the issues discussed, and finally there is an appendix listing the data on texts in COOEE. 


\section{Kira Eghbal-Azar:}

\section{Gurrumul at the Theaterhaus Stuttgart 2009}

$\mathrm{T}$

he musician and songwriter Geoffrey Gurrumul Yunupingu was born on Elcho Island close to Arnhem Land in 1970. He is a member of the Gumatj clan, who belong to the Yolngu. Last year he was on his first official European tour. Like his debut album "Gurrumul" which was released in February 2008 the tour was a great success. His album received the attention of the international music industry and entered the charts in Australia and Europe. It also won several awards. That is why Skinnyfish Music has just released a video called "Gurrumul - Live and Behind the Scenes" which Qantas screened as part of its in-flight program on international flights between $1^{\text {st }}$ Dec 2009 and $30^{\text {th }}$ May 2010.

Gurrumul formerly performed within the famous band Yothu Yindi as a percussionist until 1992. Yothu Yindi was formed by Gurrumul's uncle Mandawuy Yunupingu. Currently Gurrumul is a member of the Saltwater Band. But it is possible that Gurrumul will become even more famous and successful than both of these Aboriginal bands.

He performed with his non-indigenous band at the Theaterhaus Stuttgart on the $28^{\text {th }}$ of October. The instrumentation consists of two guitars, one contrabass and two violins. Thus, Gurrumul doesn't use any traditional instrumentation at all. He creates a new personal style by combining traditional stories of the Gumatj clan and personal stories of himself and his family with contemporary instrumentation and song styles. Thereby he sings almost all texts in his mother tongue Yolngu matha. Hence his music is world music that connects different cultures. He makes that statement clear with his band, the instrumentation, the vocalization, himself and the opening band Wordfly, a non-indigenous Australian band from Darwin. 
Worldfly starts the concert in a lovely manner. They play inoffensive music and sing thoughtful texts. You can imagine yourself being in a pub in Darwin listening to them and just having a nice evening with friends. But when the concert started with Worldfly I was not prepared for that unbelieveable sound and feelings Gurrumul and his band are able to create. You can feel Arnhemland and its surrounding islands. You can get itchy feet for the Top End and cry together with Gurrumul about that overwhelming beautiful landscape with its endless expanse that you never get to see in Europe. As Gurrumul mother says about her blind son: "He cannot see, but he can feel."

Gurrumul tells indigenous stories to pass them down to his people and to us listeners like Aborigines are used to pass down their stories and knowledge orally. In his concert this transmission is framed by videos. As an intro to the concert you can see his uncle and his parents at their homeland talking about Gurrumul and his music. When Gurrumul sings his songs you can read the texts in English at the back of the room. You also get additional information in English about the meaning of the songs and stories. That really leads you into the matter even if you have absolutely no previous knowledge about Aboriginal cultures. The texts give the listeners a deeper understanding and hence a deeper sympathy for Gurrumul and his people. The concert ends with a video about Gurrumul's career. So the circle is closed. This arrangement really succeeds.

The most famous song Wiyathul is about the orange footed scrub fowl which has a close connection to the Gumatj. The fowls call narrates about the ancestors and their (lost) land. But Gurrumul never deals with politics like Yothu Yindi. His aim is cross cultural sensitivity. His message could be interpreted like: Be strong and stay upright no matter in which society you live.

Reviewers have called Gurrumul's voice striking and "the voice of an angel." But between his songs he never speaks. This is not only because he hardly speaks English, he is also very shy. In his clan his parents spoke for him and he was responsible for the music. During the concert the contra bassist player speaks for Gurrumul. He tells 
us about Gurrumul's worldwide success that started in Stuttgart. He tells us about the meaning of Gurrumuls music and that Gurrumul plays the guitar the other way around, in case you aren't aware of it. Then the band plays one song like Gurrumul. Thereby the band shows their empathy for Gurrumul and passes it to the audience by showing how hard it is to hold and play instruments the other way around and that Gurrumul really has great talent. He even taught himself playing didgeridoo, keyboard, percussion and guitar. Gurrumul's concerts offer a touching experience that you'll never forget. 


\section{Die Beitragenden/The Contributors}

Elisabeth Bähr (Dipl.-Päd., baehr@aboriginal-art.de) writes articles, edits books, and gives seminars about Australian indigenous art. She coedited the catalogue of the Sprengel Museum exhibition "Eine Reise zu den großen Dingen" in 1995. For the next decade, she was the manager of a gallery specializing in Aboriginal art, curating the majority of such exhibitions in public galleries all over Germany.

Josef Berghold, Dr. phil. (b. 1953, josef.berghold@uni-klu.ac.at) is a social psychologist currently teaching at the Universities of Klagenfurt, Innsbruck, and Bolzano/Bozen. His main fields of research, publishing and teaching include the psychological foundations of solidarity and social Darwinism, the interpretation of unconscious motives in public life, the challenges of global society, the pathology of "neoliberalism", and the roots of prejudice and group hostility.

Nicholas Birns (born 1965) is Associate Teaching Professor at Eugene Lang College of the New School in New York City. He is editor of Antipodes and co-edited A Companion to Australian Literature Since 1900 (Camden House), a CHOICE Outstanding Academic Book. His most recent works are Theory After Theory: An Intellectual History of Literary Theory From 1950 to the 21st Century (Broadview) and the forthcoming Wiley-Blackwell Encyclopedia of Critics and Criticism.

Susanne Braun-Bau has a Ph-D in Australian Literature from the University of Wuppertal and a teaching degree in English and German from the University of Bonn. She works in the ministry of schools and education of North-Rhine Westfalia. She had lectureships and research assignments with the Universities of Wuppertal, Bamberg and Nuremberg. She also taught at German high schools for a short length of time.

Kay Dreyfus (kay.dreyfus@arts.monash.edu.au) is a research officer in the School of Music-Conservatorium at Monash University and a postgraduate student in the School of Philosophical, Historical and International Studies. For the past several years she has been researching the public and professional reception of Jewish refugee musicians in Australia, before and after WW II, with a particular interest in the Weintraub Syncopators.

Corinna Erckenbrecht, Dr. rer. nat, born 1962, is a cultural anthropologist who worked both at universities and museums of Ethnology (mainly at the Rautenstrauch-Joest-Museum für Völkerkunde at Cologne). Her main research fields are the anthropology of law, gender studies, religion, artefact collections from Aboriginal Australia and historical issues. Currently she works as a free-lance anthropologist in Cologne (www.erckenbrecht.com). 
Adele Garnier (born 1979, adele.garnier@mq.edu.au) is currently completing a PhD in politics. She is jointy affiliated with the University of Leipzig and Macquarie University, Sydney. Her PhD. compares the contemporary internationalisation of the UK's and Australia's asylum policies.

Martin Grosch, (born 1983, martin.g.grosch@googlemail.com), graduated as a geographer and political scientist at the University of Bamberg in 2009. In 2008, he spent six months in Sydney to research for his project. His main research fields are spatial planning, mobility and economic geography.

Oliver Haag studied History and Political Science at the University of Vienna, Austria. He specialised in Indigenous Australian autobiography, the German reception of Australian literature, and politics of diversity with particular focus on Australia and Germany. Oliver is the author of academic writings on published Indigenous Australian autobiographies and translated Indigenous Australian literature.

Mandy Kretzschmar (mandy_kretzschma@hotmail.com) studied American Studies, Theatre and Cultural Studies at the University of Leipzig and at the University of Georgia, U.S.A. Currently, she is enrolled as a Cotutelle PhD student at the University of Leipzig and at Macquarie University, NSW. Her research interests include Australian history and media, trans-national and global approaches to history.

Stefanie Land (stefanie.land@fu-berlin.de) studied North American Studies, Political Science, and English Literature at the Universities of Heidelberg, Berlin, and Sydney. Currently, she is completing her Magister's degree thesis on the representation of Indigenous peoples in Canadian schoolbooks at the Free University of Berlin.

Igor Maver (igor.maver@guest.arnes.si) is Professor of English at the University of Ljubljana in Slovenia, where he teaches literatures written in English in the Department of English. He studied at the University of Ljubljana and the University of Queensland. He teaches Shakespeare, Australian, New Zealand and Canadian literatures, contemporary American novel, English mediaeval literature and the post-colonial Anglophone novel.

Horst Prießnitz (Professor Emeritus, University of Wuppertal) is one of the founding fathers of GAST; he was our first president.

Arno Russegger is Associate Professor at the Department of German Philology of the University of Klagenfurt. His main research fields include modern and postmodern Austrian literature, intermediality (film and literature, filmscripts as texts), children's literature. Further information about his publications: https://campus.uniklu.ac.at/fodok/ uebersicht. do?persnr $=647 \&$ tabindex $=$ 
Anja Schwarz holds a PhD from the Freie Universität Berlin and teaches Post-colonial Literatures at the University of Konstanz. She has published on historical re-enactmtents, multicultural politics and the Australian beach as a postcolonial site of memory.

Andrew Taylor is Professor Emeritus at Edith Cowan University, Perth. He has published widely on Australian poetry, including the study Reading Australian Poetry (St Lucia, University of Queensland Press, 1987). Among his numerous volumes of poetry are Collected Poems (Salt Publishing, UK, 2004) and The unhaunting (Salt Publishing, UK, 2009).

Jitka Vlčková (vlckova@phil.muni.cz) is assistant professor at the Department of English and American Studies at Masaryk University Brno, Czech Rep. She has published studies in sociolinguistics and text analysis, some of them related to the Australian context. Her main research fields are issues connected with linguistic demonstrations of ideology and acculturation. She is a member of the advisory board of Brno Studies in English.

Adi Wimmer (b.1949, adi.wimmer@uni-klu.ac.at) became the editor of this journal in 2007 and is currently the Chairperson of GASt. A recent publication is Australian Film: Cultures, Identities, Texts, WVT (Trier), 2008. 